AUTARQUIA ASSOCIADA À UNIVERSIDADE DE SÃO PAULO

ESTUDO SOBRE A DETERMINAÇÃO DE ELEMENTOS TÓXICOS (As, Cu E Hg) EM AMOSTRAS DE BIOMONITORES DA POLUIÇÃO ATMOSFÉRICA PELO MÉTODO DE ANÁLISE POR ATIVAÇÃO COM NÊUTRONS

\title{
CAROLINE PEREZ
}

\begin{abstract}
Dissertação apresentada como parte dos requisitos para obtenção do Grau de Mestre em Ciências na Área de Tecnologia Nuclear - Aplicações
\end{abstract}

Orientadora:

Profa. Dra. Mitiko Saiki 


\section{INSTITUTO DE PESQUISAS ENERGÉTICAS E NUCLEARES}

Autarquia associada à Universidade de São Paulo

Estudo sobre a determinação de elementos tóxicos (As, Cu e Hg) em amostras de biomonitores da poluição atmosférica pelo método de análise por ativação com nêutrons

\section{CAROLINE PEREZ}

Dissertação apresentada como parte dos requisitos para obtenção do Grau de Mestre em Ciências na Área de Tecnologia Nuclear - Aplicações

Orientadora:

Profa. Dra. Mitiko Saiki

Versão Corrigida

São Paulo 
"Tente mover o mundo - o primeiro passo será mover a si mesmo." Platão 


\section{AGRADECIMENTOS}

À Dra. Mitiko Saiki, pela orientação, paciência e pelos valiosos conhecimentos transmitidos.

Aos meus pais, Marco e Maria das Graças, que sempre me incentivaram, apoiaram e proporcionaram todas condições para que eu chegasse até aqui.

Ao meu irmão, Marcus, pela amizade, companheirismo e por sempre ter participado de todas as etapas da minha vida.

Ao meu namorado, André, por todo o carinho, parceria e por ter me acompanhado ao longo de toda caminhada do mestrado, mesmo nos momentos mais difíceis.

Aos meus sogros, Lúcia e Geraldo, por me acolherem como filha e por terem me recebido em sua casa inúmeras vezes quando, por algum motivo, eu não conseguia voltar do IPEN para minha casa.

Aos amigos de longa data, Juliana, Victor, Guilherme, Raul, Fernanda, Thaysa, Luiza, Mayara e Bruno, entre tantos outros, pelos desabafos, risadas e por sempre estarem dispostos a me ajudar.

Aos colegas e professores do CRPq, pelos conselhos e pela ajuda, direta ou indireta, nesse trabalho.

Ao Prof. Dr. Guilherme Soares Zahn, pela ajuda no entendimento das interferências de "pico soma" e pelo auxílio na plotagem dos espectros.

À Eliane e ao Leandro do CRPq, por terem cedido as amostras de cascas de árvore e de bromélias.

Ao Instituto de Pesquisas Energéticas e Nucleares (IPEN - CNEN/SP), pela oportunidade concedida para o desenvolvimento deste trabalho.

À Comissão Nacional de Energia Nuclear (CNEN) pela bolsa de mestrado concedida. 
À Fundação de Amparo à Pesquisa do Estado de São Paulo (FAPESP) e ao Conselho Nacional de Desenvolvimento Científico e Tecnológico (CNPq), pelo apoio financeiro. 


\section{RESUMO}

PEREZ, C. Estudo sobre a determinação de elementos tóxicos (As, Cu e $\mathrm{Hg}$ ) em amostras de biomonitores da poluição atmosférica pelo método de análise por ativação com nêutrons. 2018, 110 p. Dissertação (Mestrado em Tecnologia Nuclear) - Instituto de Pesquisas Energéticas e Nucleares - IPEN CNEN/SP. São Paulo.

No biomonitoramento da poluição atmosférica, as determinações de elementos tóxicos têm sido de suma importância para identificação das suas fontes de emissão e dos efeitos ocasionados com a sua exposição. Consequentemente diferentes técnicas analíticas vêm sendo aprimoradas e aplicadas para essa finalidade, entre elas, a análise por ativação com nêutrons (NAA). Essa técnica apresenta vantagens para a quantificação de elementos poluentes, devido a sua capacidade de análise multielementar e a sua alta sensibilidade, precisão e exatidão dos resultados. Entretanto, nos trabalhos de biomonitoramento, a NAA não tem sido muito utilizada na determinação dos elementos tóxicos $\mathrm{As}, \mathrm{Cu}$ e $\mathrm{Hg}$. O objetivo deste trabalho foi estabelecer um procedimento adequado de NAA para a determinação de $\mathrm{As}$, $\mathrm{Cu}$ e $\mathrm{Hg}$ em amostras de biomonitores da poluição atmosférica (liquens, bromélias e cascas de árvores). O procedimento de NAA consistiu em irradiação sob fluxo de nêutrons térmicos alíquotas de amostras juntamente aos padrões sintéticos dos elementos, seguida de espectrometria de raios gama. Foram realizados ensaios preliminares de NAA para definição das condições de irradiação e de medição para determinação desses três elementos e, para isso, foram analisados diversos materiais de referência certificados (MRCs). Os resultados de As, $\mathrm{Cu}$ e $\mathrm{Hg}$ nos MRCs demonstraram boa exatidão e precisão (HORRAT < 2 e IZscorel < 2). Isto é, para determinação de As, foi verificado que irradiações de $1 \mathrm{~h}$ e tempo de decaimento de $1 \mathrm{~d}$ para as medições permitem obter resultados satisfatórios. $O$ As foi encontrado em todas as espécies de biomonitores analisadas e os valores de limites de detecção foram inferiores às suas frações mássicas, demostrando que o procedimento proposto pode ser 
satisfatoriamente utilizado nas análises de biomonitores. Nas determinações de Cu nos MRCs, foi observado que esse elemento pode ser quantificado por meio das irradiações de $20 \mathrm{~s}$ e de $1 \mathrm{~h}$ pelas medições de ${ }^{66} \mathrm{Cu}$ e de ${ }^{64} \mathrm{Cu}$, respectivamente. Entretanto, dependendo da amostra, nas irradiações de $1 \mathrm{~h}$ pode ocorrer a interferência da alta atividade do ${ }^{24} \mathrm{Na}$. Nas análises de biomonitores, os tempos de irradiação de $1 \mathrm{~h}$ e de decaimento de $1 \mathrm{~d}$ foram mais apropriados que as irradiações de curta duração de $20 \mathrm{~s}$, uma vez que os dados obtidos apresentaram boa precisão e limites de detecção mais baixos que os das irradiações de $20 \mathrm{~s}$. Para determinação de $\mathrm{Hg}$, verificou se que não há perda desse elemento nas irradiações realizadas em invólucros ou cápsulas de polietileno. O invólucro foi escolhido devido ao seu baixo custo e a facilidade de aquisição. $\mathrm{O}$ tempo de irradiação de $1 \mathrm{~h}$ foi apropriado para evitar os problemas das interferências espectrais do ${ }^{198} \mathrm{Au}$ e ${ }^{75} \mathrm{Se}$, que foram mais evidentes para $8 \mathrm{~h}$ de irradiação. $\mathrm{O} \mathrm{Hg}$ não foi detectado em nenhum dos biomonitores analisados e os limites de detecção calculados variaram de 0,01 a $6,8 \mu \mathrm{g} \mathrm{g}{ }^{-1}$. Pelos resultados obtidos neste trabalho, concluiu-se que o procedimento de NAA estabelecido pode ser aplicado no biomonitoramento de $\mathrm{As}$, $\mathrm{Cu}$ e $\mathrm{Hg}$ da poluição aérea e cabe ainda ressaltar que esses três elementos podem ser determinados por meio de uma única irradiação de $1 \mathrm{~h}$, dependendo dos teores destes elementos nas amostras.

Palavras-chave: análise por ativação com nêutrons, biomonitores, poluição atmosférica, arsênio, cobre, mercúrio. 


\begin{abstract}
PEREZ, C. A study on toxic elements (As, $\mathrm{Cu}$ and $\mathrm{Hg}$ ) determinations in biomonitors of atmospheric pollution by neutron activation analysis. 2018, 110 p. Dissertação (Mestrado em Tecnologia Nuclear) - Instituto de Pesquisas Energéticas e Nucleares - IPEN - CNEN/SP. São Paulo.
\end{abstract}

In the atmospheric pollution biomonitoring, the determination of toxic elements has been of major importance to the identification of their emission sources and of the caused effects by their exposure. Consequently, different analytical techniques have been improved and applied for this purpose, among them, the neutron activation analysis (NAA). This technique presents advantages for the quantification of pollutant elements due to its capability of multielemental analyses and its high sensitivity, precision and accuracy of results. However, in biomonitoring works, NAA has not been widely used in the determination of toxic elements $\mathrm{As}, \mathrm{Cu}$ and $\mathrm{Hg}$. The aim of this study was to establish adequate procedures of NAA for $\mathrm{As}, \mathrm{Cu}$ and $\mathrm{Hg}$ determination in biomonitors of atmospheric pollution (lichens, bromeliads and tree barks). The NAA procedure consisted of irradiation, under thermal neutron flux, aliquots of samples with the elemental synthetic standards, followed by gamma ray spectrometry. Preliminary assays of NAA were carried out to define the irradiation and measurement conditions for these three elements determinations. For this purpose, several certified reference materials (CRMs) were analyzed. Results of $\mathrm{As}, \mathrm{Cu}$ and $\mathrm{Hg}$ obtained in CRMs demonstrated good precision and accuracy of obtained data (HORRAT $<2$ and IZ scorel $<2$ ). For As determination, irradiation time of $1 \mathrm{~h}$ and $1 \mathrm{~d}$ of decay time for the measurements allowed to obtain satisfactory results. Arsenic was detected in all analyzed samples of biomonitors and the detection limits were lower than its mass fractions, showing that the proposed procedure can be satisfactorily used in the biomonitor analyses. In Cu determination in CRMs, it was verified that this element could be quantified using irradiations of $20 \mathrm{~s}$ and of $1 \mathrm{~h}$ and by measuring ${ }^{66} \mathrm{Cu}$ and ${ }^{64} \mathrm{Cu}$, respectively. However, depending on the sample, the interference 
of high activity of ${ }^{24} \mathrm{Na}$ may occur. In the analyses of biomonitors, irradiation time of $1 \mathrm{~h}$ and decay time of $1 \mathrm{~d}$ were more appropriate to obtain precise results than the short-term irradiations of $20 \mathrm{~s}$. For $\mathrm{Hg}$ determination, loss of this element from polyethylene capsules or involucres was not observed and the involucres were selected due to its low cost and easy acquisition. Irradiation time of $1 \mathrm{~h}$ was chosen to avoid the problems of spectral interferences of ${ }^{198} \mathrm{Au}$ and ${ }^{75} \mathrm{Se}$, which were more evident for $8 \mathrm{~h}$ of irradiation. Mercury was not detected in the analyzed biomonitor samples and the detection limits varied from 0.01 to $6.8 \mu \mathrm{g} \mathrm{g}^{-1}$. Based on the obtained results, it was concluded that the established NAA procedure can be applied in the biomonitoring of $\mathrm{As}, \mathrm{Cu}$ and $\mathrm{Hg}$ of atmospheric pollution, and it should be noted that these three elements could be determined by a single irradiation of $1 \mathrm{~h}$ depending on the mass fractions of the elements in the samples.

Key words: neutron activation analysis, biomonitors, atmospheric pollution, arsenic, copper, mercury 


\section{LISTA DE TABELAS}

Tabela 1 - Materiais de referência certificados (MRCs) analisados com as frações mássicas de $\mathrm{As}, \mathrm{Cu}$ e $\mathrm{Hg}$ e suas respectivas incertezas apresentadas nos certificados.

Tabela 2 - Dados das amostras de casca de árvore analisadas neste trabalho. .41 Tabela 3 - Dados da coleta de líquen realizada nas dependências do IPEN.......42

Tabela 4 - Dados das amostras de bromélias analisadas neste trabalho. 44

Tabela 5 - Porcentagens de umidade determinadas nos materiais de referência certificados (MRCs) utilizados

Tabela 6 - Porcentagens de umidade residual determinadas nas amostras de biomonitores da poluição atmosféricas analisadas.

Tabela 7 - Concentrações de elementos nas soluções utilizadas para o preparo dos padrões sintéticos e massas dos elementos irradiados.

Tabela 8 - Dados nucleares e condições de irradiação utilizadas para a determinação de arsênio, cobre e mercúrio neste trabalho. 58

Tabela 9 - Massas de arsênio, cobre e mercúrio no invólucro de polietileno, na tira de papel-filtro, na amostra de material de referência e no padrão sintético. ...63 Tabela 10 - Média das frações mássicas de arsênio, em $\mu_{\mathrm{g} \mathrm{g}}{ }^{-1}$, obtidas por meio de irradiações de 1 e $8 \mathrm{~h}$ nos materiais de referência certificados IAEA-336 Trace and minor elements in lichen e BCR 482 Trace elements in lichen. 65 Tabela 11 - Limites de detecção (LD) e de quantificação (LQ) de arsênio, em $\mu \mathrm{g}$ $\mathrm{g}^{-1}$, obtidos para os materiais de referência certificados IAEA-336 Trace and minor elements in lichen e BCR 482 Trace elements in lichen.

Tabela 12 - Média das frações mássicas de arsênio, em $\mu_{\mathrm{g} \mathrm{g}}{ }^{-1}$, obtidas por meio de irradiações de $1 \mathrm{~h}$ e pela medida do pico de energia de raios gama de 559,10 keV nos materiais de referência certificados

Tabela 13 - Limites de deteç̧ão (LD) e de quantificação (LQ) de arsênio, em $\mu \mathrm{g}$ $\mathrm{g}^{-1}$, obtidos pela medida do pico de energia de raios gama de 559,10 keV nos materiais de referência certificados irradiados por $1 \mathrm{~h}$ 69

Tabela 14 - Frações mássicas médias, limites de detecção (LDs) e de quantificação (LQs) de arsênio obtidos nas análises das cascas de árvore. Resultados em $\mu \mathrm{g} \mathrm{g}^{-1}$. 
Tabela 15 - Fração mássica média, limites de detecção (LD) e de quantificação

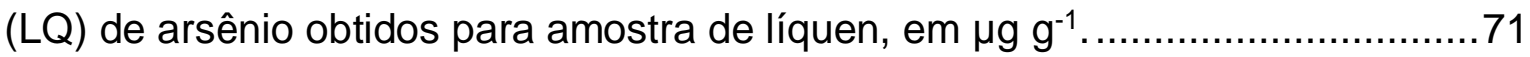
Tabela 16 - Frações mássicas médias, limites de detecção (LDs) e de quantificação (LQs) de arsênio obtidos nas amostras de bromélias em $\mu \mathrm{g} \mathrm{g}^{-1} \ldots . .72$ Tabela 17 - Frações mássicas médias de cobre, em $\mu \mathrm{g} \mathrm{g}^{-1}$, obtidas nos materiais de referência certificados por meio de irradiações de curta duração.

Tabela 18 - Valores de limite de detecção (LD) e de quantificação (LQ) obtidos nas determinações de cobre nos materiais de referência certificados por meio das irradiações de curta duração.

Tabela 19 - Resultados de cobre, em $\mu_{\mathrm{g} \mathrm{g}}{ }^{-1}$, obtidas por meio de irradiações de 1 $\mathrm{h}$ nos materiais de referência certificados.

Tabela 20 - Frações mássicas médias, limites de detecção (LD) e de quantificação (LQ) de cobre obtidos por meio de irradiações de $1 \mathrm{~h}$ e de $20 \mathrm{~s}$ nas amostras de casca de árvore, em $\mu \mathrm{g} \mathrm{g}^{-1}$.

Tabela 21 - Fração mássica média, limites de detecção (LD) e de quantificação (LQ) de cobre obtidos na análise de líquen por meio de irradiações de $1 \mathrm{~h}$. Resultados em $\mu \mathrm{g} \mathrm{g}^{-1}$. .81

Tabela 22 - Médias das frações mássicas, limites de detecção (LD) e de quantificação (LQ) de cobre, em $\mu \mathrm{g} \mathrm{g}^{-1}$, obtidos nas análises de bromélias. Tempo de irradiação $=1 \mathrm{~h}$.

Tabela 23 - Valores de limites de detecção (LD) e de quantificação (LQ), em $\mu \mathrm{g} g$ 1 , obtidos nas análises de bromélias $\left(t_{i}=20 \mathrm{~s}\right)$.

Tabela 24 - Frações mássicas de mercúrio no MRC IAEA-085 Human Hair, $\mu \mathrm{gg}$ g 1, obtidas para diferentes condições de irradiação.

Tabela 25 - Taxas de contagens corrigidas $\left(\mathrm{A}_{0}\right)$ para o tempo de decaimento $t_{0}=$ 0 dos padrões sintéticos de mercúrio em função de tempos de decaimento. Condições de irradiação utilizadas: cápsula e involucro de polietileno e tempos de irradiação de 1 e $8 \mathrm{~h}$.

Tabela 26 - Frações mássicas médias de mercúrio, em $\mu \mathrm{g} \mathrm{g}^{-1}$, obtidas nos MRCs pela medida do ${ }^{197} \mathrm{Hg}$ e do ${ }^{203} \mathrm{Hg}$ e em diferentes tempos de decaimento $\left(\mathrm{td}_{1}, \mathrm{td}_{2} \mathrm{e}\right.$ $\left.\mathrm{td}_{3}\right)$.

Tabela 27 - Limites de detecção (LD) e de quantificação (LQ) de mercúrio, em $\mu \mathrm{g}$ $\mathrm{g}^{-1}$, obtidos para os materiais de referência certificados analisados. 
Tabela 28 - Limites de detecção (LD) e de quantificação (LQ) de mercúrio, em $\mu \mathrm{g}$ $\mathrm{g}^{-1}$, obtidos nas análises de biomonitores da poluição atmosférica.

Tabela 29 - Condições apropriadas para a determinação de As, Cu e Hg por NAA em amostras de casca de árvore, líquens e bromélias.

Tabela A.1 - Resultados individuais das frações mássicas de As nos materiais de referência certificados. Tempo de irradiação $=1 \mathrm{~h}$. 96

Tabela A.2 - Resultados individuais das frações mássicas de As nas amostras de casca de árvore

Tabela A.3 - Resultados individuais das frações mássicas de As na amostra de líquen. 98

Tabela A.4 - Resultados individuais das frações mássicas de As nas amostras de bromélia analisadas. 98

Tabela B.1 - Resultados individuais das frações mássicas de Cu nos materiais de referência certificados irradiados por $20 \mathrm{~s}$ 99

Tabela B.2 - Resultados individuais das frações mássicas de Cu nos materiais de referência certificados irradiados por $1 \mathrm{~h}$ 100

Tabela B.3 - Resultados individuais das frações mássicas de Cu nas amostras de casca de árvore irradiadas por $1 \mathrm{~h}$. 101

Tabela B.4 - Resultados individuais das frações mássicas de Cu nas amostras de casca de árvore irradiadas por $20 \mathrm{~s}$. 102

Tabela B.5 - Resultados individuais das frações mássicas de Cu na amostra de líquen irradiada por $1 \mathrm{~h}$. 103

Tabela B.6 - Resultados individuais das frações mássicas de Cu nas amostras de bromélia irradiadas por $1 \mathrm{~h}$ 103

Tabela C.1 - Resultados individuais das frações mássicas de Hg nos materiais de referência certificados. 104 


\section{LISTA DE FIGURAS}

Figura 1 - Esquema ilustrativo do processo de captura de nêutrons por um núcleo alvo, seguida pela emissão de raios gama. .25

Figura 2 - Esquema explicativo das reações de interferência primárias na NAA, em que $x$ pode ser $y, p, \alpha, 2 n$, etc., $x^{\prime}$ é diferente de $x, x^{\prime \prime}$ pode ser igual ou diferente de $x$ na reação básica.

Figura 3 - Espectro de raios gama de ${ }^{82} \mathrm{Br}$ na região de 500 a $1500 \mathrm{keV}$ obtido nas medições realizadas no detector de Ge hiperpuro. .34

Figura 4 - Curva de decaimento composta de uma amostra contendo dois radionuclídeos com picos sobrepostos.

Figura 5 - Fotografias de exemplares de árvores das espécies (a) Tipuana (Tipuana tipu) e (b) Sibipiruna (Poincianella pluviosa).

Figura 6 - Fotografia de um exemplar do líquen da espécie Canoparmelia texana, no tronco da árvore.

Figura 7 - Fotografias de exemplares das bromélias das espécies: (a) Tillandsia recurvata e (b) Tillandsia usneoides.

Figura 8 - Fotografia de invólucros de polietileno contendo padrões sintéticos de As, $\mathrm{Cu}$ e $\mathrm{Hg}$

Figura 9 - Fotografia do dispositivo de alumínio ("coelho") de dimensões 7,0 × 2,1 cm utilizado nas irradiações de longa duração.

Figura 10 - Fotografia de suporte de aço inoxidável ("panelinha") com $3 \mathrm{~cm}$ de diâmetro.

Figura 11 - Fotografia do dispositivo de polietileno ("coelho") de dimensões 5,6 x 2,3 cm utilizado nas irradiações de curta duração. .56

Figura 12 - Fotografia da Estação Pneumática no. 4 do reator nuclear de pesquisas IEA-R1. .57

Figura 13 - Valores de HORRAT (a) e de Z score (b) na determinação de arsênio nos materiais de referência certificados. 68

Figura 14 - Valores de HORRAT obtidos na determinação de arsênio nas amostras de casca de árvore. .70

Figura 15 - Valores de HORRAT na determinação de arsênio nas amostras de bromélias analisadas. .73 
Figura 16 - Valores de HORRAT (a) e de Z score (b) obtidos na determinação de cobre nos materiais de referência certificados.

Figura 17 - Valores de HORRAT obtidos na determinação de cobre nas amostras de casca de árvore.

Figura 18 - Espectro de raios gama na região de 200 a $300 \mathrm{keV}$ da medida do MRC IAEA-085 Human Hair irradiado por $8 \mathrm{~h}$ em invólucro de polietileno. .84 Figura 19 - Espectro de raios gama na região de 55 a $90 \mathrm{keV}$ da medida do MRC IAEA-085 Human Hair irradiado por $8 \mathrm{~h}$ em invólucro de polietileno. 85 Figura 20 - Taxas de contagens obtidas nas contagens do padrão sintético de mercúrio em função do tempo de decaimento pela medida do ${ }^{197} \mathrm{Hg}$ (a) e pela medida do ${ }^{203} \mathrm{Hg}$ (b) para diferentes condições de irradiação. 88 


\section{SUMÁRIO}

1 INTRODUÇÃO

1.1 Toxicidade dos elementos arsênio, cobre e mercúrio e dificuldades na sua determinação pela análise por ativação com nêutrons

1.1.1 Arsênio (As) ................................................................... 19

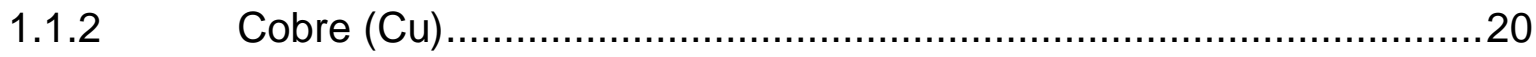

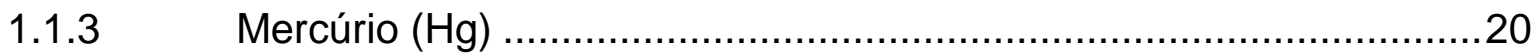

1.2 Biomonitores da poluição atmosférica analisados no presente estudo: líquens, bromélias e cascas de árvore............................................................21

2 OBJETIVO

3 FUNDAMENTOS TEÓRICOS DA ANÁLISE POR ATIVAÇÃO COM

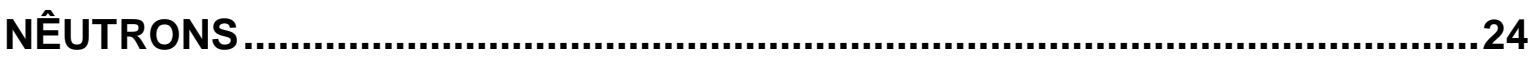

4 CONSIDERAÇÕES SOBRE INTERFERÊNCIAS NA ANÁLISE POR

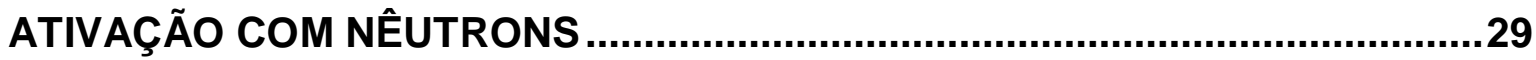

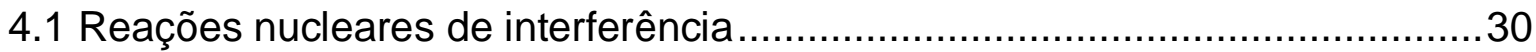

4.1.1 Reações nucleares de interferência primária ..................................................30

4.1.2 Reações nucleares de interferência secundárias ocasionadas por partículas

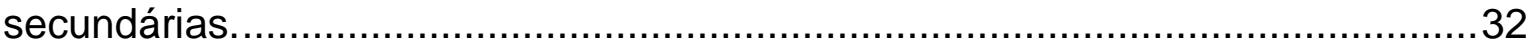

4.2 Interferências provenientes da reação de fissão .................................................32

4.3 Interferências causadas pela radioatividade natural ......................................32

4.4 Interferências causadas por efeitos de pico soma ...........................................33

4.5 Interferências devido às altas atividades de radionuclídeos dos elementos

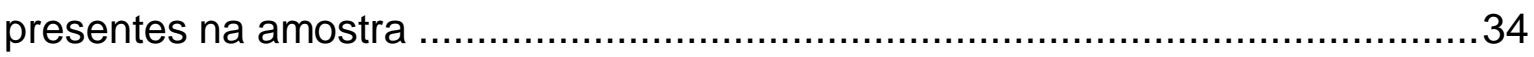

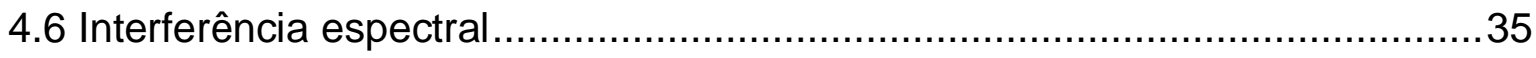

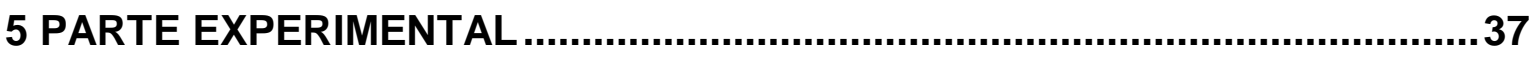

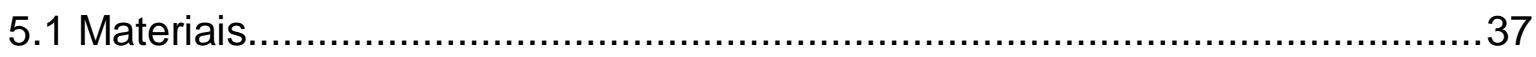

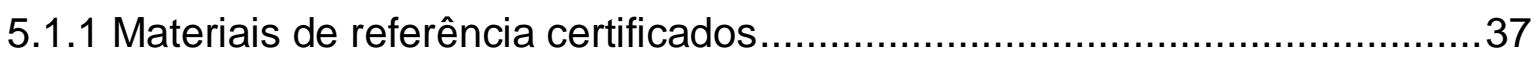


5.1.2.2 Amostra de líquen

5.1.2.3 Amostras de bromélias.

5.2 Pesagem dos materiais de referência certificados e das amostras de biomonitores para a análise

5.3 Determinação de umidade dos materiais de referência certificados e das amostras de biomonitores

5.4 Preparo dos padrões sintéticos de arsênio, cobre e mercúrio

5.5 Procedimento dos ensaios preliminares 50

5.5.1 Determinação de arsênio, cobre e mercúrio nos invólucros de polietileno e nas tiras de papel filtro utilizados para irradiação 50

5.5.2 Escolha das condições para a determinação de arsênio 50

5.5.3 Escolha das condições de irradiação para a determinação de cobre 51 5.5.4 Escolha do tempo e do recipiente para irradiação para a determinação de $\mathrm{Hg}$.

5.6 Procedimento de NAA para a análise 52

5.6.1 Procedimento para irradiações de longa duração no reator nuclear para a determinação de arsênio, cobre e mercúrio

5.6.2 Procedimento para irradiações de curta duração no reator nuclear para a determinação de cobre 55

5.6.3 Identificação dos radionuclídeos e cálculo das frações mássicas. 57

5.7 Tratamento dos dados obtidos. 59

5.7.1 Avaliação da precisão dos resultados 59

5.7.2 Diferença padronizada (Z score) 60

5.7.3 Cálculo dos limites de detecção e de quantificação 61

6 RESULTADOS E DISCUSSÃO. 62

6.1 Resultados da determinação de arsênio, cobre e mercúrio nos invólucros de polietileno e nas tiras de papel-filtro. 
6.2 Resultados da determinação de arsênio

6.2.1 Escolha das condições para a determinação de arsênio ..............................64

6.2.2 Resultados de arsênio obtidos nos materiais de referência certificados ......67

6.2.3 Resultados de arsênio em amostras de biomonitores ..................................69

6.2.3.1 Resultados de arsênio obtidos nas cascas de árvore ...............................69

6.2.3.2 Resultados de arsênio obtidos na amostra de líquen ...............................71

6.2.3.3 Resultados de arsênio obtidos em bromélias..........................................71

6.3 Resultados da determinação de cobre .......................................................

6.3.1 Resultados de cobre obtidos nos materiais de referência certificados..........73

6.3.1.1 Resultados do cobre nos materiais de referência certificados por meio de

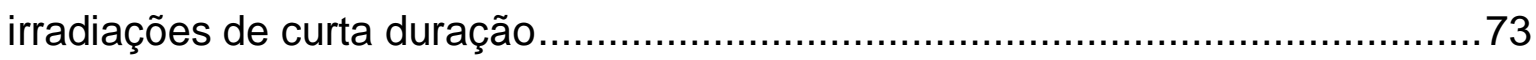

6.3.1.2 Resultados de cobre obtidos nos materiais de referência certificados por

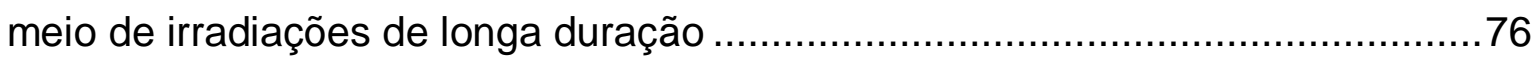

6.3.2 Resultados de cobre obtidos em amostras de biomonitores........................78

6.3.2.1 Resultados de cobre obtidos nas cascas de árvore ................................78

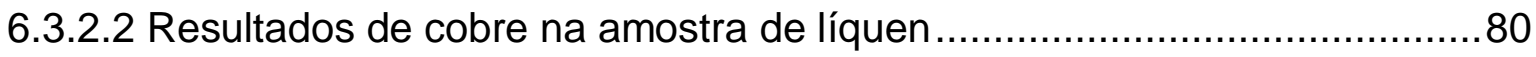

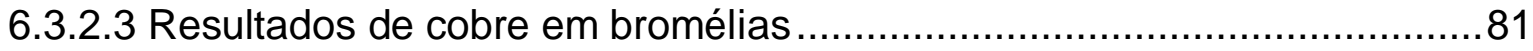

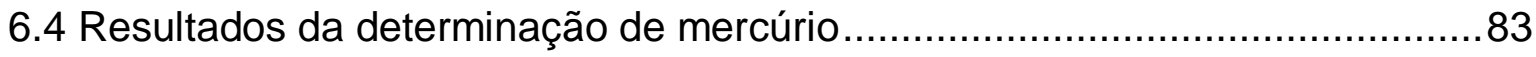

6.4.1 Resultados obtidos no estabelecimento das condições de irradiação para a

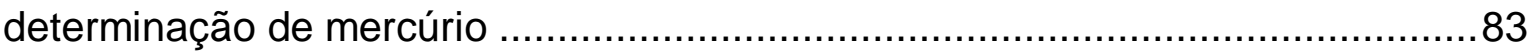

6.4.1.1 Avaliação da perda de mercúrio durante a irradiação ..................................83

6.4.1.2 Avaliação da perda de mercúrio após a irradiação ...................................85

6.4.2 Resultados de mercúrio nos materiais de referência certificados ..................88

6.4.3 Resultados de mercúrio nas amostras de biomonitores .............................91

6.5 Condições experimentais apropriadas estabelecidas para a determinação de

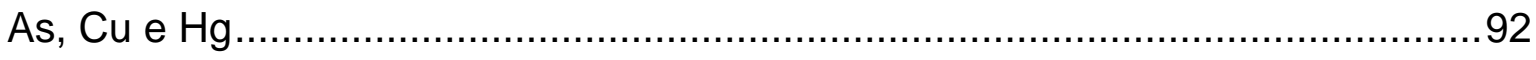

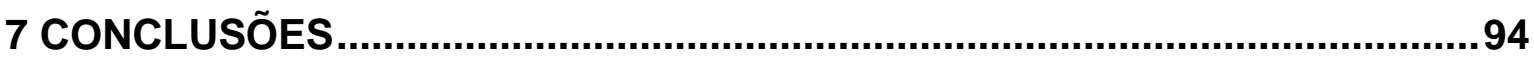


APÊNDICE A - Resultados individuais das frações mássicas de As nos materiais de referência certificados e nas amostras de biomonitores da poluição atmosférica ..............................................................................96 APÊNDICE B - Resultados individuais das frações mássicas de Cu nos materiais de referência certificados e nas amostras de biomonitores da poluição atmosférica .99 APÊNDICE C - Resultados individuais das frações mássicas de $\mathrm{Hg}$ nos materiais de referência certificados ..........................................................104

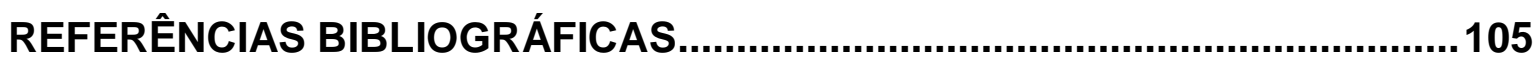




\section{INTRODUÇÃO}

A poluição atmosférica é considerada como um dos maiores riscos ambientais à saúde humana (BATTISTA e DE LIETO VOLLARO, 2017), sendo relacionada a doenças respiratórias e cardiovasculares, cânceres e malformações congênitas (FREITAS et al., 2013). Segundo a Organização Mundial da Saúde (OMS), no ano de 2012, aproximadamente sete milhões de pessoas morreram prematuramente devido à exposição a poluentes aéreos (WHO, 2014).

Esse tipo de poluição representa um dos maiores problemas nos ambientes urbanos, devido ao rápido crescimento populacional e à expansão das atividades industriais (BILO et al., 2017). Por isso, é de grande interesse de diversos pesquisadores ao redor do mundo desenvolver ou aprimorar métodos analíticos para a determinação de elementos tóxicos oriundos das emissões antrópicas e naturais de poluentes atmosféricos.

Consequentemente, neste campo de pesquisa, diversos métodos para quantificação de elementos químicos vêm sendo aplicados utilizando técnicas como a espectrometria de absorção atômica (AAS) (BARANDOVSKI et al., 2013), espectrometria de massa com fonte de plasma acoplado indutivamente (ICP-MS) (AHMED et al., 2016), espectrometria de emissão atômica com fonte de plasma acoplado indutivamente (ICP-AES) (MONNA et al., 2017; BARANDOVSKI et al., 2013), espectrometria de emissão óptica com fonte de plasma acoplado indutivamente (ICP-OES) (MORINA et al., 2017) e a análise por ativação com nêutrons (NAA) (LAZO et al., 2018).

A NAA é considerada como uma técnica vantajosa para a determinação de contaminantes atmosféricos, uma vez que suas características, como a possibilidade de uma análise multielementar e seus baixos limites de detecção, fazem com que a determinação de diversos elementos de interesse ambiental seja viável (ALMEIDA et al., 2012). Além disso, a NAA apresenta vantagens frente a outras técnicas, como a ICP-MS e ICP-AES, devido ao fato de se tratar de uma técnica não destrutiva, que requer manipulação mínima da amostra (BEDREGAL et al., 2014; NOYORI et al., 2017). Entretanto, nem todos 
os elementos têm sido detectados ou determinados com boa exatidão por essa técnica, como é o caso do arsênio $(\mathrm{As})$, do cobre $(\mathrm{Cu})$ e do mercúrio $(\mathrm{Hg})$, principalmente quando se trata da análise de amostras ambientais de biomonitores da poluição atmosférica, como os liquens, as bromélias e as cascas de árvore. Em geral, esses elementos estão presentes em teores muito baixos nesse tipo de matriz.

A seguir, são apresentadas as principais dificuldades na determinação do As, Cu e Hg pela NAA, bem como as características toxicológicas desses elementos.

\subsection{Toxicidade dos elementos arsênio, cobre e mercúrio e dificuldades na sua determinação pela análise por ativação com nêutrons}

\subsubsection{Arsênio (As)}

O As é um elemento tóxico com alto potencial carcinogênico (LIU et al., 2018). No meio ambiente, esse elemento pode ocorrer de forma natural, ou de forma antrópica, decorrente de emissões industriais, queima de carvão e de combustíveis fósseis e do uso de produtos agrícolas contendo este elemento (IFFLAND, 1994). De acordo com Tasić et al. (2017), indivíduos que residem próximos a fontes emissoras de As têm maior chance de desenvolver câncer de pulmão.

Esse elemento vem sendo determinado pela NAA em diversos tipos de matriz, como solos, sedimentos (BADAWY et al., 2017), alimentos (YU et al., 2015) e medicamentos (CESNEK et al., 2017). Porém, no caso das amostras ambientais de biomonitores da poluição atmosférica, não há na literatura muitos dados da determinação de As utilizando a técnica de NAA devido às suas baixas concentrações e às interferências causadas pela ativação de alguns elementos presentes nessas amostras, como $\circ \mathrm{Na}, \circ \mathrm{Br}$ e o $\mathrm{Sb}$. Os problemas sobre as interferências nas determinações estão apresentados no Capítulo 4, nos itens 4.5 e 4.6 dessa dissertação. 


\subsubsection{Cobre $(\mathrm{Cu})$}

O Cu é um elemento indispensável para os organismos vivos, uma vez que ele é necessário ao funcionamento de diversas metaloenzimas (XU et al., 2018; MOGHADAM et al, 2016). Porém, esse elemento pode tornar-se tóxico quando presente no organismo em quantidades excessivas, ocasionando doenças como a de Wilson, a de Menke e a cirrose infantil (GOYER e CLARKSOM, 2001). Devido às suas diversas aplicações industriais e domésticas, o Cu tem sido despejado no meio ambiente em altas quantidades (DIVSAR et al., 2015).

No caso da determinação do Cu pela NAA, dois radioisótopos desse elemento podem ser utilizados: o ${ }^{64} \mathrm{Cu}\left(\mathrm{t}_{1 / 2}=12,7 \mathrm{~h}\right.$ e $\left.\mathrm{E}_{\mathrm{Y}}=1345,77 \mathrm{keV}\right)$, e o ${ }^{66} \mathrm{Cu}$ $\left(t_{1 / 2}=5,10\right.$ min e $\left.E_{Y}=1039,20 \mathrm{keV}\right)$ (IAEA, 1990). Entretanto, esse elemento não apresenta características muito favoráveis para ativação com nêutrons, uma vez que os seus isótopos alvos apresentam valores baixos de secção de choque para nêutrons térmicos (4,28 barns para o ${ }^{63} \mathrm{Cu}$ e 2,48 barns para o ${ }^{65} \mathrm{Cu}$ ) e de integral de ressonância para nêutrons epitérmicos (4,88 barns para o ${ }^{63} \mathrm{Cu}$ e 2,63 barns para o ${ }^{65} \mathrm{Cu}$ ) (IAEA, 1990). Além disso, dependendo do tipo de amostra, a alta atividade do ${ }^{24} \mathrm{Na}$ pode interferir na medição do ${ }^{64} \mathrm{Cu}$, que apresenta meia-vida bastante próxima a do ${ }^{24} \mathrm{Na}\left(\mathrm{t}_{1 / 2}=14,96 \mathrm{~h}\right)$.

\subsubsection{Mercúrio $(\mathrm{Hg})$}

O Hg é um elemento que provoca efeitos adversos à saúde humana $\mathrm{e}$ ao meio ambiente, despertando a atenção do mundo inteiro devido à sua volatilidade, persistência e bioacumulação (UNEP, 2013). A toxicidade desse elemento depende da sua forma química, concentração, via de exposição e da vulnerabilidade do indivíduo exposto (DRASCH, 1994). Suas principais fontes antrópicas de emissões para a atmosfera são as usinas de energia movidas a carvão, atividades de mineração, incineração de lixo e processos industriais usados em fundições e produção de cimento (ŠPIRIĆ et al., 2014). A exposição 
ao mercúrio orgânico vem sendo relacionada a desordens neurológicas e mentais, além de efeitos no sistema cardiovascular (ROMAN et al., 2011).

Pela NAA, O $\mathrm{Hg}$ pode ser determinado pela medida do ${ }^{197} \mathrm{Hg}\left(\mathrm{t}_{1 / 2}=\right.$ $64,16 \mathrm{~h}$ e $\left.\mathrm{E}_{\mathrm{Y}}=77,34 \mathrm{keV}\right)$, ou pela medida do ${ }^{203} \mathrm{Hg}\left(\mathrm{t}_{1 / 2}=46,61\right.$ d e $\mathrm{E}_{\mathrm{Y}}=279,20$ $\mathrm{keV})$ (IAEA, 1990). A principal dificuldade na determinação de $\mathrm{Hg}$ pela NAA é a perda por volatilização desse elemento durante a irradiação no reator, requerendo uso de ampolas de quartzo como recipientes para irradiação (ŻMIJEWSKA, 1977; ANDERSON, 2009). O uso de ampolas de quartzo como recipiente para irradiação evitaria esta perda de $\mathrm{Hg}$, entretanto não é adequado devido à dificuldade em transferir a amostra irradiada da ampola para um recipiente de contagem. Além disso, a ampola se torna bastante radioativa devido à ativação do sódio presente no vidro quartzo.

Face ao exposto, julgou-se importante realizar um estudo do procedimento de análise por ativação com nêutrons para a quantificação dos elementos tóxicos As, $\mathrm{Cu}$ e $\mathrm{Hg}$ em amostras de líquens, bromélias e cascas de árvore, utilizadas como biomonitores da poluição atmosférica.

\subsection{Biomonitores da poluição atmosférica analisados no presente estudo: líquens, bromélias e cascas de árvore.}

Biomonitores da poluição atmosférica são organismos (ou parte de organismos) capazes de fornecer informações quantitativas sobre o meio ambiente, enquanto bioindicadores são organismos (ou parte de organismos) que proporcionam a obtenção de informações qualitativas sobre o meio ambiente (MARKERT, 2007). O monitoramento biológico de poluentes atmosféricos vem sendo muito utilizado, uma vez que ele apresenta vantagens frente ao monitoramento realizado com o uso de matrizes abióticas devido ao seu baixo custo e à facilidade de cultivo dos biomonitores (CONTI et al., 2016). 
Um biomonitoramento pode ocorrer de forma ativa ou passiva. No biomonitoamento ativo, biomonitores criados em laboratórios são expostos de forma padronizada em campo por um período definido. Já no biomonitoramento passivo, os organismos que já ocorrem naturalmente no ecossistema de interesse são utilizados (MARKERT, 2007).

Dentre os diversos tipos de biomonitores utilizados para avaliação da poluição atmosférica, estão os liquens, as bromélias e as cascas de árvore. Os liquens são considerados excelentes ferramentas para o biomonitoramento da poluição atmosférica, pois esses organismos são capazes de responder a diferentes níveis de poluentes presentes no ar e de viver por muitos anos em condições extremas (VAN DER WAT e FORBES, 2015). O mecanismo de absorção de poluentes pelo líquen ocorre pela sua habilidade de capturar elementos químicos e partículas atmosféricas por troca iônica e quelação ao longo de toda sua superfície (BERLIZOV et al., 2007; CONTI et al., 2016), permitindo assim, a identificação e a avaliação dos níveis de concentrações de poluentes atmosféricos (VAN DER WAT e FORBES, 2015).

Assim como os liquens, algumas espécies de bromélias do gênero Tillandsia também são capazes de acumular elementos em seus tecidos, pois a nutrição dessas plantas é completamente independente do solo, isto é, os nutrientes absorvidos por elas são obtidos diretamente do ar (BERMUDEZ et al., 2009; MONNA et al., 2017; TECHATO et al., 2014).

Já as cascas de árvores apresentam geralmente uma estrutura porosa, que permite que as partículas atmosféricas sejam eficientemente acumuladas e retidas (BERLIZOV et al., 2007). O uso da casca como biomonitor apresenta vantagens, como a grande área superficial da casca, o longo ciclo de vida da árvore e facilidade de amostragem (ZHOU et al., 2015) e de identificação das espécies arbóreas quando comparada a outras espécies de biomonitores. 


\section{OBJETIVO}

O objetivo geral deste trabalho foi estabelecer as condições experimentais adequadas do método de análise por ativação com nêutrons para determinação de $\mathrm{As}, \mathrm{Cu}$ e $\mathrm{Hg}$ em amostras de biomonitores de poluentes atmosféricos.

Os seguintes objetivos específicos fizeram parte do desenvolvimento deste trabalho:

- Estabelecimento das condições apropriadas de irradiação no reator e medição de atividades gama para determinação de $\mathrm{As}$, $\mathrm{Cu}$ e $\mathrm{Hg}$ pelo método de NAA em amostras de biomonitores da poluição atmosférica;

- Controle da qualidade analítica dos resultados com relação à exatidão e precisão pela análise de materiais de referência certificados.

- Determinação de limites de detecção e de quantificação dos elementos pelo procedimento estabelecido para análise de liquens, bromélias e cascas de árvores;

- Aplicação do procedimento proposto nas análises de amostras de líquens, bromélias e cascas de árvore.

Com o desenvolvimento deste trabalho, espera-se obter dados que permitam comprovar a qualidade dos resultados da determinação de $\mathrm{As}$, $\mathrm{Cu}$ e $\mathrm{Hg}$ pela NAA em amostras de biomonitores da poluição aérea. Dessa forma, buscouse tornar disponível procedimentos apropriados para a obtenção de resultados de excelente qualidade analítica na análise de biomonitores da poluição atmosférica. 


\section{FUNDAMENTOS TEÓRICOS DA ANÁLISE POR ATIVAÇÃO COM NÊUTRONS}

A técnica utilizada no presente trabalho foi a análise por ativação com nêutrons (NAA). Neste Capítulo, será apresentado, de maneira breve, o princípio dessa técnica.

A NAA baseia-se na conversão de núcleos estáveis em núcleos radioativos por meio da irradiação de uma amostra com nêutrons (GREENBERG et al., 2011). Os núcleos radioativos formados emitem radiação gama que pode ser utilizada para a identificação e quantificação do elemento que deu origem a esse radionuclídeo formado (GREENBERG et al., 2011; HAMIDATOU et al., 2013).

Na Figura 1, a sequência de eventos que ocorrem durante a irradiação de uma amostra com nêutrons é apresentada. Nesse processo, um núcleo atômico captura um nêutron durante a irradiação, resultando na formação de um núcleo composto (GREENBERG et al., 2011; HAMIDATOU et al., 2013), que se desexcita quase instantaneamente, passando para uma configuração que emite um ou mais raios gama "prontos" (HAMIDATOU et al., 2013). Geralmente, essa nova configuração produz um núcleo radioativo que também sofre desexcitação, emitindo um ou mais raios gama de decaimento (ou atrasados) e uma partícula $\beta$ (HAMIDATOU et al., 2013).

Após a irradiação, os raios gama de decaimento emitidos pela amostra podem ser medidos utilizando-se um detector semicondutor de alta resolução, como o de germânio hiperpuro (HAMIDATOU et al., 2013). Dessa maneira, a identificação de cada radionuclídeo formado na amostra pode ser realizada pela meia-vida e pelas energias de raios gama (HAMIDATOU et al., 2013). 
Figura 1 - Esquema ilustrativo do processo de captura de nêutrons por um núcleo alvo, seguida pela emissão de raios gama.

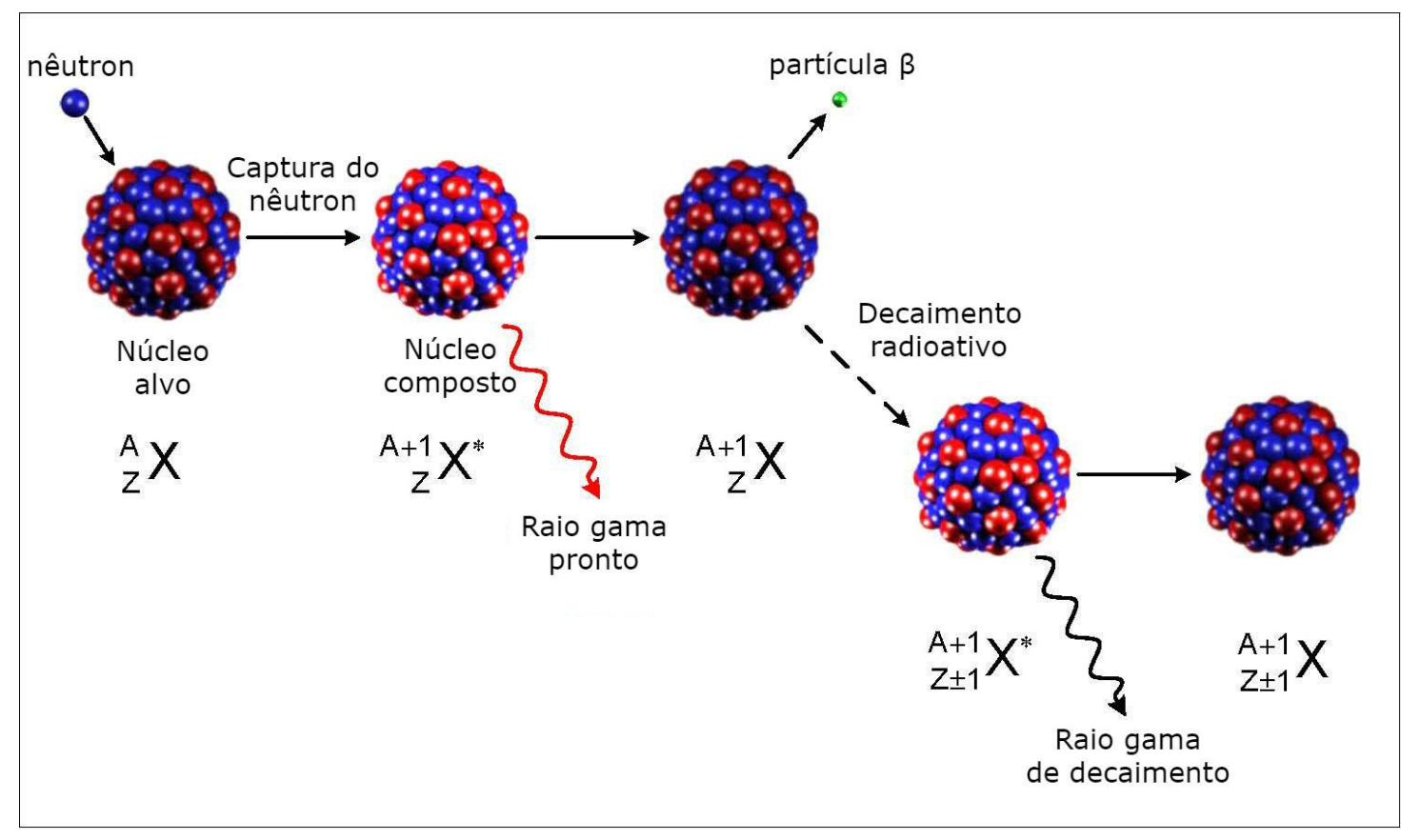

Fonte: adaptado de HAMIDATOU et al., 2013.

A atividade gama induzida a um elemento após certo tempo de irradiação (ti) é dada por (DE SOETE et al., 1972):

$$
\mathrm{A}=\frac{\left\{\epsilon \phi \sigma \mathrm{N} \mathrm{m} \mathrm{f}\left[1-\mathrm{e}^{-693 \mathrm{ti} / \mathrm{t} 1 / 2}\right]\right\}}{\mathrm{M}}
$$

Em que $\mathrm{A}=$ taxa de contagens; $\epsilon=$ coeficiente de detecção ou eficiência do detector; $\Phi=$ fluxo de nêutrons, em $\mathrm{n} \mathrm{cm}^{-2} \mathrm{~s}^{-1} ; \sigma=$ secção de choque para nêutrons em $\mathrm{cm}^{2} ; \mathrm{N}=$ constante de Avogadro; $\mathrm{m}=$ massa do elemento; $\mathrm{f}=$ abundância isotópica do nuclídeo alvo; $M=$ massa atômica do elemento; $t_{i}=$ tempo de irradiação; $\mathrm{t}_{1 / 2}=$ tempo de meia-vida do radionuclídeo considerado.

A massa $m$ da relação (3.1) pode ser obtida desde que todos os seus parâmetros nucleares (meia vida, massa atômica, abundância isotópica, secção 
de choque para nêutrons, intensidade de raios gama, etc.) sejam conhecidos. Uma alternativa para evitar o uso desses parâmetros, que nem sempre estão disponíveis com uma boa exatidão, é o uso do método comparativo, em que as amostras são irradiadas simultaneamente com os padrões dos elementos a serem determinados e, após a irradiação, são medidos na mesma geometria.

Escrevendo a relação (3.1) para um mesmo elemento para a amostra e para o padrão, que foram irradiados e medidos na mesma geometria, pode-se obter as seguintes relações para as atividades $\left(A_{a, 0}\right.$ e $\left.A_{p, 0}\right)$ para tempo de decaimento $t=0$, isto é, no final da irradiação:

$$
\begin{aligned}
& A_{a, 0}=\frac{\left\{\epsilon \phi \sigma N m_{a} f\left[1-e^{-0,693 \mathrm{ti} / \mathrm{t} / 2}\right]\right\}}{M} \\
& A_{p, 0}=\frac{\left\{\epsilon \phi \sigma N \mathrm{~m}_{\mathrm{p}} \mathrm{f}\left[1-\mathrm{e}^{-0,693 \mathrm{ti} / \mathrm{t} 1 / 2}\right]\right\}}{M}
\end{aligned}
$$

Em que os índices a e $p$ referem-se à amostra e ao padrão, respectivamente. Dividindo-se a relação (3.2) por (3.3), e para o tempo de decaimento $t=t_{0}=0$, tem-se:

$$
\frac{A_{a, 0}}{A_{p, o}}=\frac{m_{a}}{m_{p}}
$$

Nessa relação (3.4), $A_{a, 0}$ e $A_{p, 0}$ são os valores das atividades em taxas de contagens da amostra e padrão, respectivamente, medidos para um mesmo tempo de decaimento. Na prática, as taxas de contagens da amostra e do padrão são medidas em tempos de decaimento diferentes ( $t_{d a}$ e $t_{d p}$, respectivamente) e, por isso, aplica-se a relação da lei de decaimento radioativo para a correção da taxa de contagens para o mesmo do tempo de decaimento.

Pela lei de decaimento radioativo, tem-se (FRIEDLANDER et al., 1981): 


$$
A=A_{0} e^{-0,693 t d / t 1 / 2}
$$

Na relação (3.5), A e $A_{0}$ são as taxas de contagens para tempos de decaimento $t_{d}$ e $t=0$, respectivamente. Escrevendo a relação (3.5) para a amostra e para o padrão, tem-se:

$$
\begin{aligned}
& A_{a}=A_{0 a} e^{-0,693 t d a / t 1 / 2} \\
& A_{p}=A_{0 p} e^{-0,693 t d p / t 1 / 2}
\end{aligned}
$$

Substituindo equações (3.6) e (3.7) na equação (3.4), tem-se:

$$
\mathrm{m}_{\mathrm{a}}=\frac{\left[\mathrm{m}_{\mathrm{p}} \mathrm{A}_{\mathrm{a}} \mathrm{e}^{-0,693(\mathrm{tdp}) / \mathrm{t} 1 / 2}\right]}{\left[\mathrm{A}_{\mathrm{p}} \mathrm{e}^{-0,693(\mathrm{tda}) / \mathrm{t} 1 / 2}\right]}
$$

Sendo a concentração (ou fração mássica) do elemento na amostra $C_{a}$ $=m_{a} / M_{a}$, tem-se:

$$
\begin{aligned}
& \mathrm{C}_{\mathrm{a}}=\frac{\left[\mathrm{m}_{\mathrm{p}} \mathrm{A}_{\mathrm{a}} \mathrm{e}^{-0,693(\mathrm{tdp}) / \mathrm{t} 1 / 2}\right]}{\left[\mathrm{M}_{\mathrm{a}} \mathrm{A}_{\mathrm{p}} \mathrm{e}^{-0,693(\mathrm{tda}) / \mathrm{t} 1 / 2}\right]} \\
& \mathrm{ou} \\
& \mathrm{C}_{\mathrm{a}}=\frac{\left[\mathrm{m}_{\mathrm{p}} \mathrm{A}_{\mathrm{a}} \mathrm{e}^{0,693(\mathrm{tda}-\mathrm{tdp}) / \mathrm{t} 1 / 2}\right]}{\left[\mathrm{M}_{\mathrm{a}} \mathrm{A}_{\mathrm{p}}\right]}
\end{aligned}
$$

Em que os índices a e $p$ se referem a amostra e padrão, respectivamente; $M_{a}=$ massa total de amostra; $m_{p}=$ massa do elemento no 
padrão; $C_{a}=$ fração mássica do elemento na amostra; $t_{1 / 2}=$ meia vida do radionuclídeo considerado e td $=$ tempo de decaimento.

O termo $e^{0,693(\text { tda - tdp)/t1/2 }}$ da relação (3.10) permite o cálculo das taxas de contagens da amostra e do padrão para o mesmo tempo de decaimento. Essa relação foi utilizada no cálculo das frações mássicas dos elementos neste trabalho. 


\section{CONSIDERAÇÕES SOBRE INTERFERÊNCIAS NA ANÁLISE POR ATIVAÇÃO COM NÊUTRONS}

Neste Capítulo, o problema das interferências na NAA, que muitas vezes impedem a determinação confiável dos elementos, será abordado.

A possibilidade da ocorrência de interferências na NAA depende, primeiramente, da composição da amostra, das propriedades nucleares dos elementos presentes na amostra e da energia do espectro de nêutrons utilizado para irradiação (TÖLGYESSY e KRYŠ, 1989).

Nesse Capítulo, serão descritas as seguintes interferências que podem ocorrer no método instrumental da NAA:

- reações nucleares de interferência (primárias e secundárias);

- $\quad$ interferências provenientes da reação de fissão;

- interferências causadas pela radioatividade natural;

- interferências causadas por efeitos de pico soma;

- interferências devido às altas atividades de determinados radionuclídeos que podem mascarar as atividades mais baixas de radionuclídeos de interesse;

- interferências causadas por radionuclídeos gama emissores de energias muito próximas (interferência espectral).

Em geral, a ativação com nêutrons é aplicada com base nas características nucleares dos elementos que, quando ativados com nêutrons térmicos (nêutrons com energia próxima a 0,025 eV), formam radionuclídeos. Porém, algumas interferências podem ocorrer quando o núcleo alvo interage com nêutrons epitérmicos (energia entre 1 eV e $100 \mathrm{keV}$ ) e, principalmente, quando interage com nêutrons rápidos (energia maior que $100 \mathrm{keV}$ ) (COSTA, 2007). Em matrizes complexas, diferentes nuclídeos podem formar o mesmo radionuclídeo por ativação ou por decaimento radioativo, como será mostrado a seguir. 


\subsection{Reações nucleares de interferência}

\subsubsection{Reações nucleares de interferência primária}

As reações nucleares de interferência primária podem ser de primeira ou segunda ordem, sendo que para cada uma delas existe um tipo A e B.

- Reações de interferência de primeira ordem

No caso das reações de interferência de primeira ordem do tipo $A$, o mesmo radionuclídeo de interesse é formado por meio de reações com nêutrons de dois ou mais nuclídeos estáveis, como no caso do ${ }^{24} \mathrm{Na}$, que pode ser formado nas seguintes reações: ${ }^{23} \mathrm{Na}(\mathrm{n}, \mathrm{y}){ }^{24} \mathrm{Na},{ }^{24} \mathrm{Mg}(\mathrm{n}, \mathrm{p}){ }^{24} \mathrm{Na}$ e ${ }^{27} \mathrm{Al}(\mathrm{n}, \alpha){ }^{24} \mathrm{Na}$ (DE SOETE et al., 1972; TÖLGYESSY e KRYŠ, 1989). Essa interferência pode ser séria dependendo da concentração relativa dos nuclídeos alvos, da razão entre fluxo de nêutrons rápidos e térmicos utilizados e das secções de choque para nêutrons envolvidas (DE SOETE et al., 1972).

Nas reações de interferência de primeira ordem do tipo $B$, um radionuclídeo pode ser formado por uma reação nuclear, ou pelo decaimento de um produto de uma reação nuclear, como no caso do ${ }^{202} \mathrm{Ti}$, que pode ser formado pela reação ${ }^{203} \mathrm{Ti}(\mathrm{n}, 2 \mathrm{n})^{202} \mathrm{Ti}$ e pelo decaimento do ${ }^{202 \mathrm{~m}} \mathrm{~Pb}\left({ }^{202 \mathrm{~m}} \mathrm{~Pb} \stackrel{\beta}{\rightarrow}{ }^{202} \mathrm{Ti}\right)$, formado na reação ${ }^{204} \mathrm{~Pb}(\mathrm{n}, 3 \mathrm{n}){ }^{202 \mathrm{~m}} \mathrm{~Pb}$ (TÖLGYESSY e KRYŠ, 1989).

- Reações de interferência de segunda ordem

Esse tipo de interferência envolve mais de uma reação nuclear. Nas reações de interferência de segunda ordem do tipo $A$, um radionuclídeo se forma em uma reação nuclear e, em seguida, sofre uma reação nuclear. Um exemplo desse caso é o ${ }^{60 \mathrm{~m}} \mathrm{Co}$, que se forma na reação ${ }^{59} \mathrm{Co}(\mathrm{n}, \mathrm{y}){ }^{60 \mathrm{~m}} \mathrm{Co}$. O ${ }^{60 \mathrm{~m}} \mathrm{Co}$ se ativa com nêutrons pela reação ${ }^{60 m} \mathrm{Co}(n, y){ }^{61} \mathrm{Co}$ (TÖLGYESSY e KRYŠ, 1989). 
Nas reações de interferência de segunda ordem do tipo $B$, um radionuclídeo se forma em uma reação nuclear, decai e o produto de decaimento desse radionuclídeo sofre outra reação nuclear, como no exemplo a seguir:

a. ${ }^{55} \mathrm{Mn}(\mathrm{n}, \mathrm{\gamma})^{56} \mathrm{Mn}$ - reação nuclear utilizada na determinação do $\mathrm{Mn}$

b. $\left.{ }^{54} \mathrm{Cr}(\mathrm{n}, \mathrm{\gamma})^{55} \mathrm{Cr} \stackrel{\beta^{-}}{\rightarrow}{ }^{55} \mathrm{Mn}(\mathrm{n}, \mathrm{y})\right)^{56} \mathrm{Mn}$.

Nesse caso, $0{ }^{56} \mathrm{Mn}$ se forma de duas maneiras: pela ativação do ${ }^{55} \mathrm{Mn}$ e pelo decaimento do ${ }^{55} \mathrm{Cr}$ (TÖLGYESSY e KRYŠ, 1989).

$\mathrm{Na}$ Figura 2, os tipos de reações de interferência primária estão sumarizados, considerando-se uma reação nuclear básica genérica $A(n, x)^{*} X$, em que $A$ é o núcleo alvo e *X o radionuclídeo de interesse.

Figura 2 - Esquema explicativo das reações de interferência primárias na NAA, em que $x$ pode ser $y, p, \alpha, 2 n$, etc., $x$ ' é diferente de $x, x^{\prime \prime}$ pode ser igual ou diferente de $x$ na reação básica.

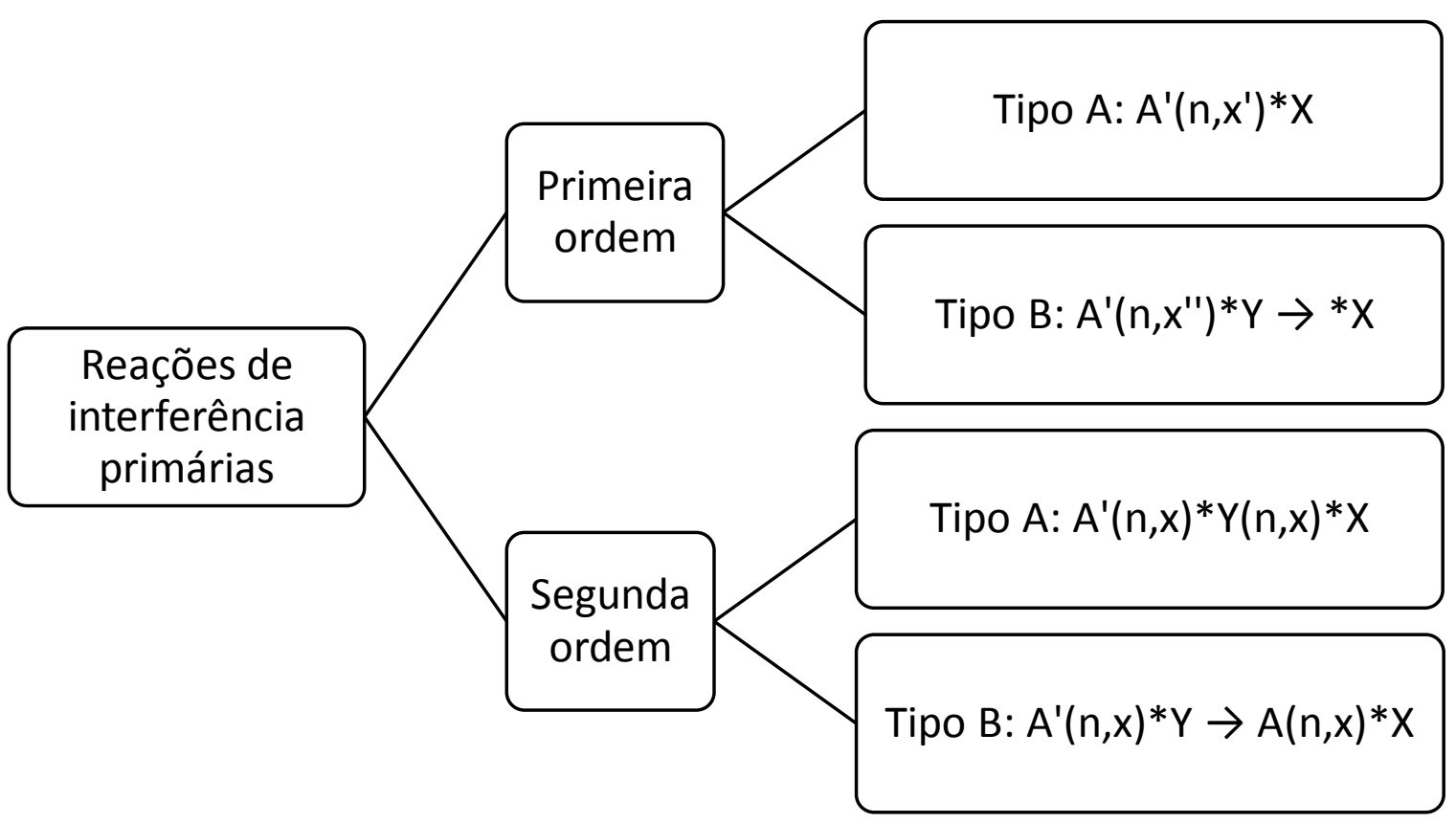

Fonte: adaptado de TÖLGYESSY e KRYŠ, 1989. 
4.1.2 Reações nucleares de interferência secundárias ocasionadas por partículas secundárias

Esse tipo de interferência ocorre se a ativação envolve um fluxo de nêutrons contendo nêutrons rápidos, que interagem com outros elementos presentes para ejetar outras partículas irradiadas, geralmente prótons, como no caso do ${ }^{18} \mathrm{~F}$, que pode ser formado pelas seguintes reações: ${ }^{19} \mathrm{~F}(\mathrm{n}, 2 \mathrm{n}){ }^{18} \mathrm{~F}$, ${ }^{17} \mathrm{O}(\mathrm{p}, \mathrm{Y}){ }^{18} \mathrm{O},{ }^{18} \mathrm{O}(\mathrm{p}, \mathrm{n}){ }^{18} \mathrm{~F}$ e ${ }^{21} \mathrm{Ne}(\mathrm{p}, \mathrm{\alpha}){ }^{18} \mathrm{~F}$ (TÖLGYESSY e KRYŠ, 1989).

\subsection{Interferências provenientes da reação de fissão}

A presença de urânio numa amostra pode interferir na determinação da concentração de alguns elementos, devido à interferência dos produtos de fissão. Nesse caso, por exemplo, com os elementos lantanídeos, como o $\mathrm{La}, \mathrm{Ce}, \mathrm{Nd}$ e Sm, podem ocorrer interferências dos produtos de fissão do U. Esses elementos formam por meio de reações $(n, y)$ os mesmos radionuclídeos daqueles produzidos na fissão do urânio (PARRY, 2003). Um exemplo disso, é o ${ }^{140} \mathrm{La}$, utilizado na determinação de La, que também é formado na fissão do urânio.

\subsection{Interferências causadas pela radioatividade natural}

A interferência causada pela radioatividade natural não tem influência em determinações baseadas em reações $(n, y)$ ou $(n, 2 n)$, uma vez que a relação entre a radioatividade natural e a radioatividade induzida deve ser a mesma para o padrão e para a amostra. Porém, quando se utiliza reações diferentes das (n,y), esse tipo de interferência pode ter efeitos mais sérios. Por exemplo, na determinação de pequenas quantidades de cálcio em uma amostra com altos teores de potássio, a interferência se manifestaria na reação ${ }^{42} \mathrm{Ca}(\mathrm{n}, \mathrm{p}){ }^{42} \mathrm{~K}$, em que a reação interferente seria ${ }^{41} \mathrm{~K}(\mathrm{n}, \mathrm{Y}){ }^{42} \mathrm{~K}$ (TÖLGYESSY e KRYŠ, 1989). 


\subsection{Interferências causadas por efeitos de pico soma}

Esses efeitos ocorrem comumente em medidas envolvendo um radionuclídeo que emite dois raios gama em sequência, ou seja, em cascata. É possível que dois raios gama de um único decaimento interajam e depositem toda sua energia no detector em um curto espaço de tempo comparado ao tempo que o detector leva para resolver os picos. Nesse caso, um "pico soma" é observado no espectro na região de altas energias, correspondendo à soma de dois raios gama individuais (KNOLL, 1989).

$\mathrm{Na}$ Figura 3, um espectro do ${ }^{82} \mathrm{Br}$ é mostrado. Nesse espectro, dois picos soma são observados: o pico soma (a), de energia de raios gama de $1173,05 \mathrm{keV}$, oriundo da soma dos picos de $554,15 \mathrm{keV}$ e $618,90 \mathrm{keV}$; e o pico soma (b), de energia de raios gama de 1330,46 keV, proveniente da soma dos picos de $554,15 \mathrm{keV}$ e $776,31 \mathrm{keV}$.

Como exemplo das interferências causadas pelos efeitos de pico soma, pode-se citar a determinação de Co em amostras com altos teores de $\mathrm{Br}$, uma vez que os picos soma oriundos do ${ }^{82} \mathrm{Br}$ podem sobrepor-se aos fotopicos do ${ }^{60} \mathrm{Co}$ de energias de raios gama de 1173,24 keV e 1332,50 keV (IAEA, 1990). 
Figura 3 - Espectro de raios gama de ${ }^{82} \mathrm{Br}$ na região de 500 a $1500 \mathrm{keV}$ obtido nas medições realizadas no detector de Ge hiperpuro.

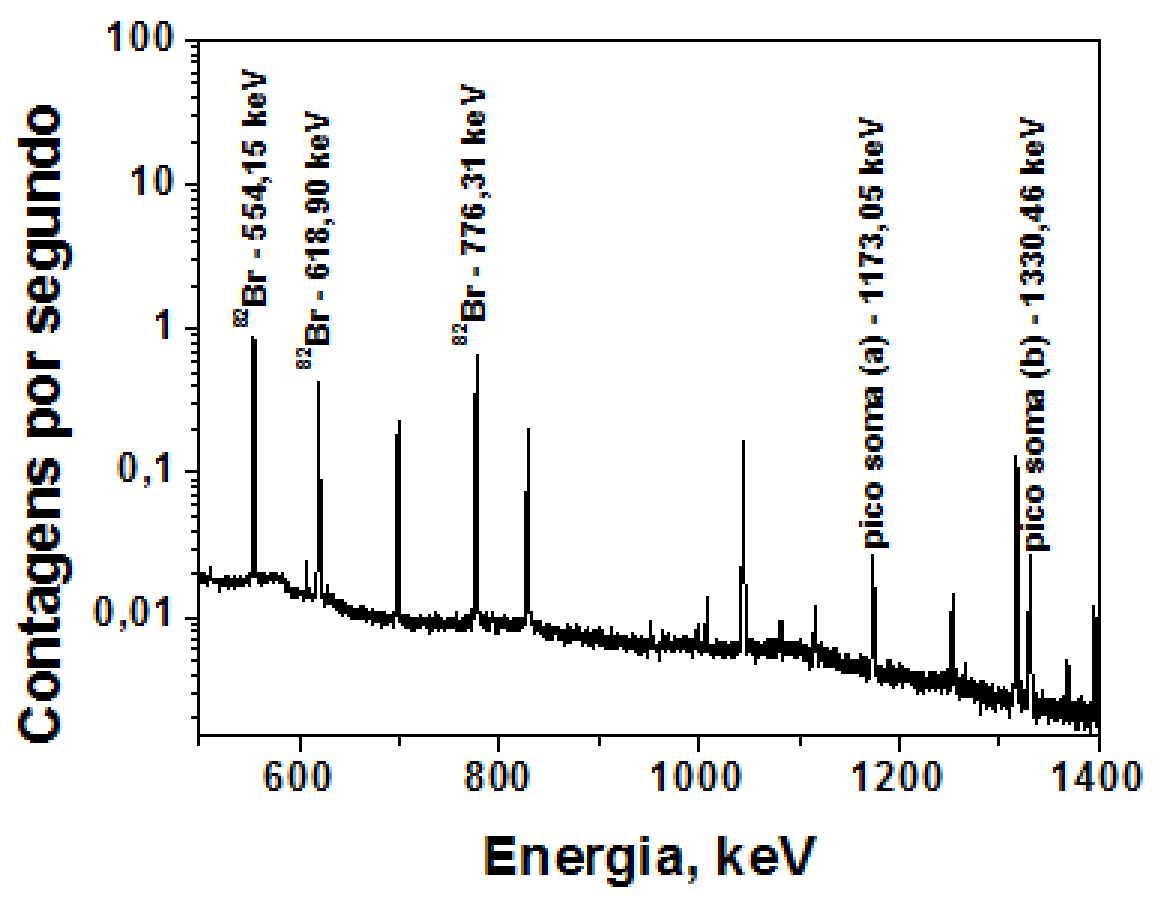

pico soma (a): $554,15 \mathrm{keV}+618,90 \mathrm{keV}=1173,05 \mathrm{keV}$;

pico soma (b): 554,15 keV + 776,31 keV $=1330,46 \mathrm{keV}$.

Fonte: autora da dissertação.

\subsection{Interferências devido às altas atividades de radionuclídeos dos elementos presentes na amostra}

Alguns elementos presentes na amostra podem formar, com a ativação, radionuclídeos que mascaram as atividades de elementos-traço de interesse presentes na amostra. Esses radionuclídeos formam um espectro de radiação de fundo com pronunciado Compton na região onde se encontram os fotopicos dos elementos de interesse. Esse efeito pode ser observado na determinação de As e $\mathrm{Cu}$ em amostras biológicas, cujos teores de sódio são altos, por exemplo. As altas atividades do ${ }^{24} \mathrm{Na}$, produzido na reação ${ }^{23} \mathrm{Na}(\mathrm{n}, \mathrm{y}){ }^{24} \mathrm{Na}$, podem mascarar as atividades menos intensas dos radionuclideos 
dos elementos de interesse para análise ${ }_{2}$ que estão presentes, em geral em baixos teores na amostra (LOVELAND et al., 2006).

\subsection{Interferência espectral}

Dois radionuclídeos podem emitir raios gama com energias bastante próximas. Por exemplo, $0{ }^{27} \mathrm{Mg}\left(\mathrm{t}_{1 / 2}=9,45 \mathrm{~min}\right.$ e $\left.\mathrm{E}_{\mathrm{V}}=843,8 \mathrm{keV}\right)$ pode interferir na análise do ${ }^{56} \mathrm{Mn}\left(\mathrm{t}_{1 / 2}=2,58 \mathrm{~h} \mathrm{e} \mathrm{E}_{\mathrm{Y}}=846,8 \mathrm{keV}\right.$ ) (MOREIRA, 2002). Esse tipo de interferência pode ocorrer na determinação de As por NAA, ao se utilizar o pico principal de ${ }^{76} \mathrm{As}\left(E_{\mathrm{Y}}=559,10 \mathrm{keV}\right)$, que pode ser sobreposto pelos picos de $554,35 \mathrm{keV}$ do ${ }^{82} \mathrm{Br}$ e de $564,24 \mathrm{keV}$ do ${ }^{122} \mathrm{Sb}$ (IAEA, 1990), dependendo da resolução do sistema de contagem ou medição utilizado e de seus teores na amostra.

Para se evitar o problema de interferência espectral, pode-se fazer uso da diferença de meia-vida dos radionuclídeos, aguardando o decaimento de um deles para fazer a medida do outro, ou utilizar picos complementares na determinação de um dos elementos, avaliando a contribuição deste elemento para o pico que será usado na determinação do outro elemento (MOREIRA, 2002).

Uma alternativa para verificar a ocorrência de uma interferência espectral, quando os radionuclídeos em questão apresentam meias-vidas diferentes, é a determinação experimental da meia-vida por meio da lei de decaimento radioativo (equação 3.5). Nessa situação, será observada uma taxa de decaimento composta, como mostrado na Figura 4, em que $C$ representa a curva de decaimento composta, $\mathrm{A}$, a curva de decaimento do radionuclídeo de meia-vida mais longa e $\mathrm{B}$, a curva de decaimento do radionuclídeo de meia-vida mais curta (LOVELAND et al., 2006). 
Figura 4 - Curva de decaimento composta de uma amostra contendo dois radionuclídeos com picos sobrepostos.

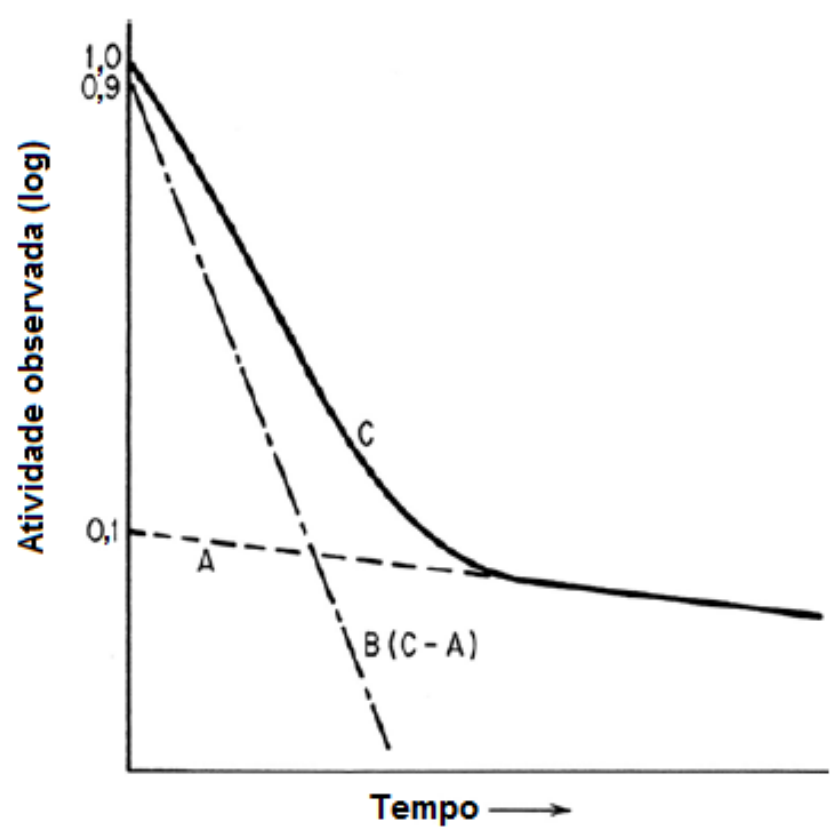

Fonte: adaptado de LOVELAND et al., 2006. 
5 PARTE EXPERIMENTAL

\subsection{Materiais}

Neste trabalho, foram analisados materiais de referência certificados e amostras ambientais constituídas de biomonitores da poluição atmosférica.

5.1.1 Materiais de referência certificados

Para o controle da qualidade analítica quanto à exatidão e precisão dos resultados, foram analisados materiais de referência certificados (MRCs), ou seja, materiais que apresentam um ou mais valores certificados por um procedimento que permite a rastreabilidade dos resultados, fornecidos juntamente a valores de incerteza para um nível de confiança estabelecido.

Procurou-se selecionar MRCs de matrizes ambientais, comumente utilizados no controle da qualidade analítica nas pesquisas de biomonitoramento, e que apresentassem valores certificados para os elementos em estudo (As, Cu e $\mathrm{Hg}$ ). Os MRCs selecionados foram aqueles procedentes das seguintes instituições: INCT (Institute of Nuclear Chemistry and Technology), IAEA (International Atomic Energy Agency), BCR (Community Bureau of Reference), NCR (National Research Council Canada) e NIST (National Institute of Standards and Technology). Esses materiais estão listados na Tabela 1, com os seus respectivos valores de frações mássicas para $\mathrm{As}, \mathrm{Cu}$ e $\mathrm{Hg}$ e suas incertezas apresentadas nos seus respectivos certificados. 
Tabela 1 - Materiais de referência certificados (MRCs) analisados com as frações mássicas de As, Cu e Hg e suas respectivas incertezas apresentadas nos certificados.

\begin{tabular}{|c|c|c|c|c|}
\hline \multirow[b]{2}{*}{ MRCs } & \multirow[b]{2}{*}{ Código } & \multicolumn{3}{|c|}{ Valores do certificado $\left(\mu \mathrm{g} \mathrm{g}^{-1}\right)$} \\
\hline & & As & $\mathrm{Cu}$ & $\mathrm{Hg}$ \\
\hline Tea Leaves & INCT-TL-1 & $0,106 \pm 0,021$ & $20,4 \pm 1,5$ & $0,00492 \pm 0,00074^{*}$ \\
\hline Trace Elements in Lichen & BCR 482 & $0,85 \pm 0,07$ & $7,03 \pm 0,19$ & $0,48 \pm 0,02$ \\
\hline $\begin{array}{l}\text { Methylmercury, Total Mercury and Other } \\
\text { Trace Elements in Human Hair }\end{array}$ & IAEA-085 & ** & $16,8(15,7-17,8)^{\star \star \star}$ & $23,2(22,4-24,0)$ \\
\hline $\begin{array}{c}\text { Dogfish Liver Certified Reference Material } \\
\text { for Trace Metals }\end{array}$ & NRC DOLT-3 & $10,2 \pm 0,5$ & $31,2 \pm 1,0$ & $3,37 \pm 0,14$ \\
\hline Bovine Liver & NIST 1577b & & $160 \pm 8$ & \\
\hline Oyster Tissue & NIST 1566b & $7,65 \pm 0,65$ & $71,6 \pm 1,6$ & $0,0371 \pm 0,0013$ \\
\hline
\end{tabular}

${ }^{*}$ Certificado com bases nos resultados de um único método analítico.

** Espaço em branco indica que não há valores nos respectivos certificados.

*** Valor informativo

Fonte: INCT, 2002; IAEA, 1999; BCR, 1995; IAEA, 2000; INCT, 2015; NCR, 2002; NIST, 1991; NIST, $2015 ;$ BCR, 1986. 
5.1.2 Amostras de biomonitores da poluição atmosférica

\subsubsection{Amostras de cascas de árvore}

Foram coletadas amostras de cascas de árvores das espécies Tipuana (Tipuana tipu) e Sibipiruna (Poincianella pluviosa), mostradas na Figura 5, na Cidade Universitária da Universidade de São Paulo (USP) no bairro do Butantã em São Paulo/SP. Essas duas espécies foram escolhidas por serem muito utilizadas para arborização, estando amplamente distribuídas nas áreas urbanas. Para coleta, considerou-se apenas a presença da espécie arbórea. As amostras foram coletas e preparadas para a análise de acordo com o procedimento descrito por Moreira et al. (2016).

Figura 5 - Fotografias de exemplares de árvores das espécies (a) Tipuana (Tipuana tipu) e (b) Sibipiruna (Poincianella pluviosa).

(a)

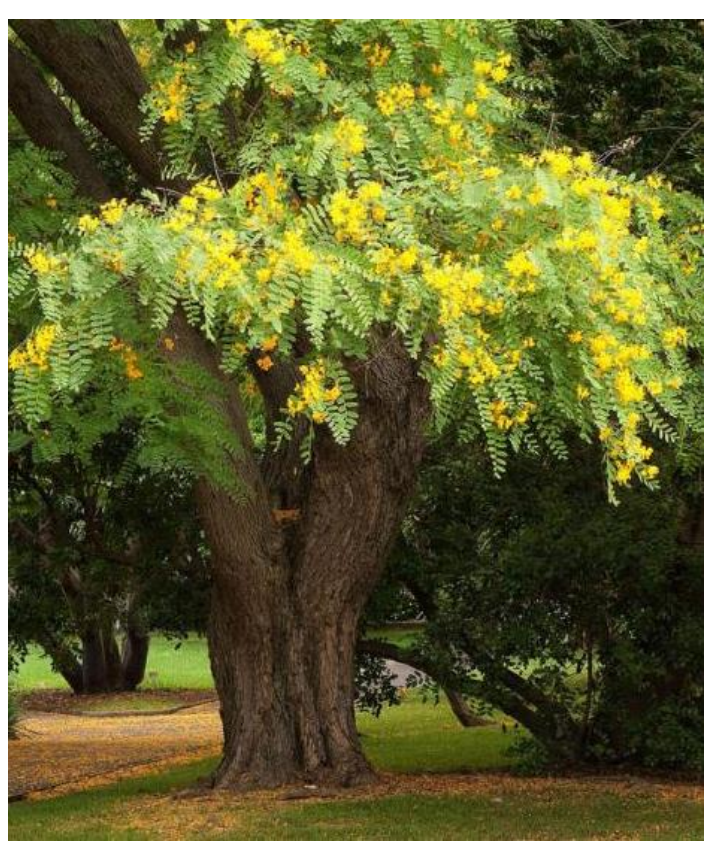

(b)

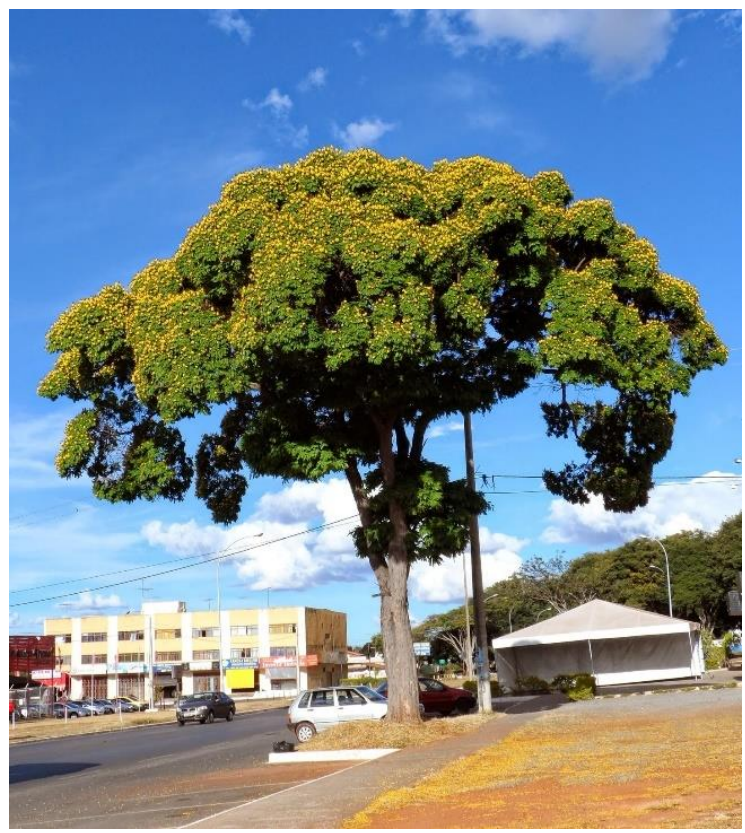

Fonte: https://www.jardineriaon.com e https://loja.paraisodasarvores.com.br, para as fotos (a) e (b), respectivamente. 
A coleta das cascas foi realizada a uma altura de 1,5 a 2,5 $\mathrm{m}$ do solo utilizando uma faca de aço inoxidável. Após coletadas, as amostras foram armazenadas em sacos de papel. O diâmetro do tronco foi medido na altura da coleta e as coordenadas geográficas dos pontos de coleta foram registradas usando um aparelho para geo-posicionamento por satélite - Global Positioning System (GPS).

No caso de coleta de amostras úmidas das cascas, uma secagem em estufa com circulação de ar forçada a uma temperatura de $40^{\circ} \mathrm{C}$ foi realizada. Para análise, as camadas superficiais das cascas foram limpas com uma escova dental com cerdas de nylon e depois raladas usando um ralador de titânio, obtendo-se amostras da camada externa superficial da casca com espessura menor que $3 \mathrm{~mm}$. Feito isso, as amostras foram submetidas à moagem em um micro moinho vibratório de ágata "Pulverisette 0" da Fritsch. Por fim, as amostras obtidas na forma de um pó fino foram colocadas em frascos de plástico, identificadas e armazenadas em dessecador.

Além das amostras coletadas, foram analisadas amostras de casca de árvore cedidas por colegas do IPEN, já recebidas na forma de pó. Na Tabela 2, a lista de amostras de cascas de árvore analisadas neste trabalho está apresentada. 
Tabela 2 - Dados das amostras de casca de árvore analisadas neste trabalho.

\begin{tabular}{|c|c|c|c|c|c|}
\hline $\begin{array}{c}\text { Código da } \\
\text { amostra }\end{array}$ & Espécie & $\begin{array}{c}\text { Data da } \\
\text { coleta }\end{array}$ & Região & Local da coleta & $\begin{array}{c}\text { Responsável } \\
\text { pela coleta }\end{array}$ \\
\hline C1 & Tipuana tipu & $12 / 2015$ & $\begin{array}{c}\text { Santo André, } \\
\text { SP }\end{array}$ & $\begin{array}{l}23^{\circ} 39^{\prime} 11.5^{\prime \prime S} \\
46^{\circ} 32^{\prime} 07.7^{\prime \prime} \mathrm{W}\end{array}$ & Eliane C. S. \\
\hline $\mathrm{C} 2$ & Tipuana tipu & $12 / 2015$ & $\begin{array}{c}\text { Santo André, } \\
\text { SP }\end{array}$ & $\begin{array}{l}23^{\circ} 39^{\prime} 10.9^{\prime \prime S} \\
46^{\circ} 29^{\prime} 19.2 " \mathrm{~W}\end{array}$ & Eliane C. S. \\
\hline C3 & Tipuana tipu & $12 / 2015$ & $\begin{array}{c}\text { Santo André, } \\
\text { SP }\end{array}$ & $\begin{array}{c}3^{\circ} 39^{\prime 2} 26.2^{\prime \prime S} \\
46^{\circ} 31^{\prime} 49.3^{\prime \prime} \mathrm{W}\end{array}$ & Eliane C. S. \\
\hline C4 & $\begin{array}{c}\text { Poincianella } \\
\text { pluviosa }\end{array}$ & $07 / 2014$ & $\begin{array}{l}\text { Jd. Helena, } \\
\text { SP }\end{array}$ & $\begin{array}{l}23^{\circ} 28^{\prime} 54.3^{\prime \prime S} \\
46^{\circ} 25^{\prime} 09.0^{\prime \prime W}\end{array}$ & Eliane C. S. \\
\hline C5 & Tipuana tipu & $11 / 01 / 2017$ & Butantã, SP & $\begin{array}{l}23^{\circ} 33^{\prime} 49.7^{\prime \prime S} \\
46^{\circ} 44^{\prime} 02.7^{\prime \prime W}\end{array}$ & Caroline/Mitiko \\
\hline C6 & $\begin{array}{c}\text { Poincianella } \\
\text { pluviosa }\end{array}$ & $11 / 01 / 2017$ & Butantã, SP & $\begin{array}{l}23^{\circ} 33^{\prime} 49.1 " \mathrm{~S} \\
46^{\circ} 44^{\prime} 02.4^{\prime \prime W}\end{array}$ & Caroline/Mitiko \\
\hline C7 & $\begin{array}{c}\text { Poincianella } \\
\text { pluviosa }\end{array}$ & $11 / 01 / 2017$ & Butantã, SP & $\begin{array}{l}23^{\circ} 33^{\prime} 45.6^{\prime \prime S} \\
46^{\circ} 44^{\prime} 03.6^{\prime \prime W}\end{array}$ & Caroline/Mitiko \\
\hline C8 & Tipuana tipu & $14 / 02 / 2017$ & Butantã, SP & $\begin{array}{l}23^{\circ} 33^{\prime} 33.7^{\prime \prime S} \\
46^{\circ} 44^{\prime} 09.2^{\prime \prime} \mathrm{W}\end{array}$ & Caroline \\
\hline C9 & $\begin{array}{c}\text { Poincianella } \\
\text { pluviosa }\end{array}$ & $14 / 02 / 2017$ & Butantã, SP & $\begin{array}{l}23^{\circ} 33^{\prime} 30.4^{\prime \prime S} \\
46^{\circ} 43^{\prime} 58.1 " \mathrm{~W}\end{array}$ & Caroline \\
\hline C10 & Tipuana tipu & $14 / 02 / 2017$ & Butantã, SP & $\begin{array}{l}23^{\circ} 33^{\prime} 37.2^{\prime \prime S} \\
46^{\circ} 43^{\prime} 33.1 " \mathrm{~W}\end{array}$ & Caroline \\
\hline C11 & Tipuana tipu & $14 / 02 / 2017$ & Butantã, SP & $\begin{array}{l}23^{\circ} 33^{\prime} 54.8^{\prime \prime S} \\
46^{\circ} 42^{\prime} 45.4^{\prime \prime} \mathrm{W}\end{array}$ & Caroline \\
\hline C12 & Tipuana tipu & $14 / 02 / 2017$ & Butantã, SP & $\begin{array}{l}23^{\circ} 33^{\prime} 51.9^{\prime \prime} \mathrm{S} \\
46^{\circ} 42^{\prime} 53.4^{\prime} \mathrm{W}\end{array}$ & Caroline \\
\hline
\end{tabular}

Fonte: autora da dissertação.

5.1.2.2 Amostra de líquen

Uma amostra de líquen da espécie Canoparmelia texana (exemplar mostrado na Figura 6) foi coletada nas dependências do IPEN. Os dados da coleta encontram-se na Tabela 3. 
Figura 6 - Fotografia de um exemplar do líquen da espécie Canoparmelia texana, no tronco da árvore.

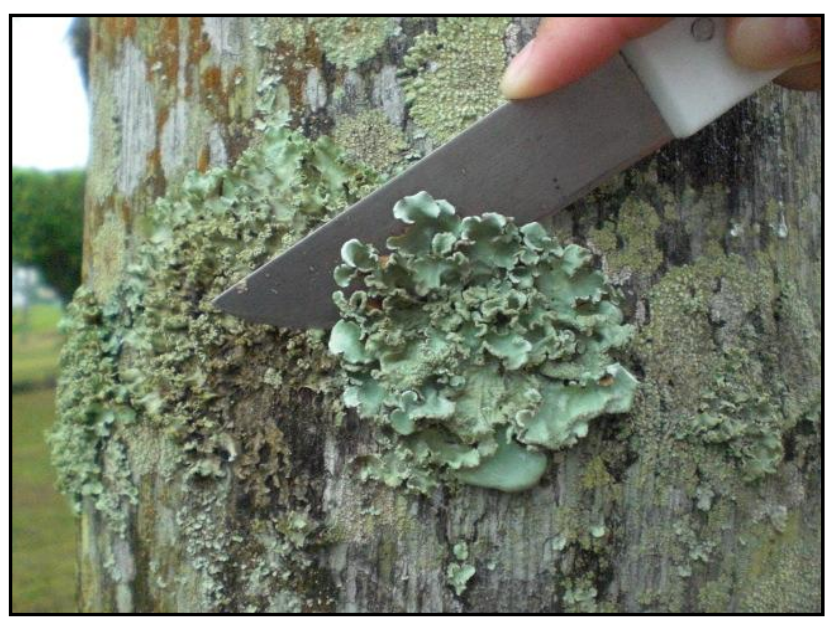

Fonte: SAIKI, M.

Tabela 3 - Dados da coleta de líquen realizada nas dependências do IPEN.

\begin{tabular}{cccccc}
\hline $\begin{array}{c}\text { Código da } \\
\text { amostra }\end{array}$ & Espécie & $\begin{array}{c}\text { Data da } \\
\text { coleta }\end{array}$ & Região & Local da coleta & $\begin{array}{c}\text { Responsável } \\
\text { pela coleta }\end{array}$ \\
\hline L1 & $\begin{array}{c}\text { Canoparmelia } \\
\text { texana }\end{array}$ & $10 / 02 / 2017$ & Butantã, SP & $\begin{array}{c}23^{\circ} 33^{\prime} 51.0^{\prime \prime S} \\
46^{\circ} 44^{\prime} 12.5^{\prime \prime}\end{array}$ & Caroline/Mitiko \\
& & & & \\
\hline
\end{tabular}

Fonte: autora da dissertação.

A coleta e o tratamento da amostra de líquen foram realizados conforme o procedimento descrito por Fuga et al. (2008). Para a coleta, utilizou-se uma faca de titânio. A limpeza da amostra coletada foi realizada por meio de exame em um microscópio estereoscópico da Marca Olympus e, posteriormente, por imersão em água purificada Milli-Q. Após a limpeza, a amostra foi liofilizada, utilizando-se um liofilizador da marca Thermo Electron, modelo Modulyo Freeze Dryer, triturada manualmente em um almofariz de ágata, colocada em frasco plástico, identificada e armazenada em dessecador. 


\subsubsection{Amostras de bromélias}

Amostras de bromélias das espécies Tillandsia recurvata e Tillandsia usneoides foram coletadas também nas dependências do IPEN utilizando-se uma faca de titânio. No tratamento, essas amostras tiveram seus talos cortados em pequenos fragmentos com o auxílio de uma tesoura com recobrimento de titânio e, posteriormente, foram limpas por imersão de cerca de $3 \mathrm{~min}$ em água purificada Milli-Q. Essas amostras, colocadas em potes de plástico, permaneceram no freezer para posterior secagem por liofilização. Foi utilizado, para liofilização, um liofilizador da marca Thermo Electron, modelo Modulyo Freeze Dryer. Para a moagem, encaminharam-se as amostras para a Faculdade de Medicina da USP, onde elas foram moídas em um moinho planetário de bolas, modelo PM200, da marca Retsch Technology GmbH.

Na Figura 7, exemplares das espécies de bromélia Tillandsia recurvata e Tillandsia usneoides são apresentados.

Figura 7 - Fotografias de exemplares das bromélias das espécies: (a) Tillandsia recurvata e (b) Tillandsia usneoides.

(a)

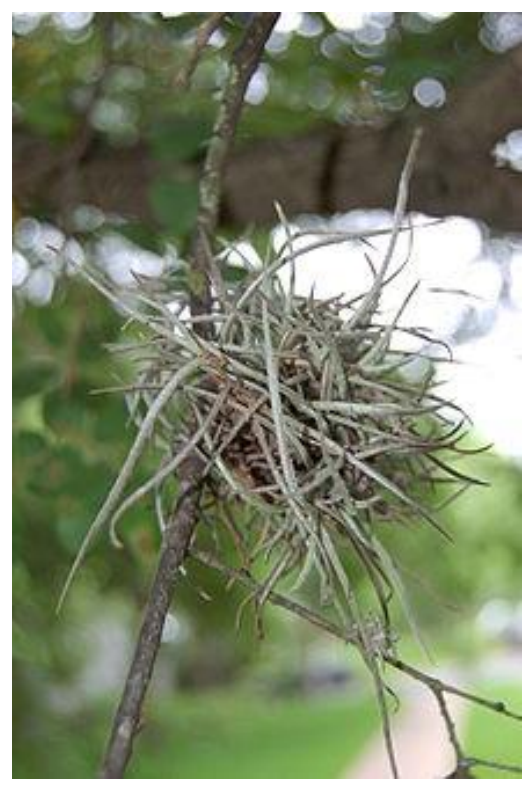

(b)

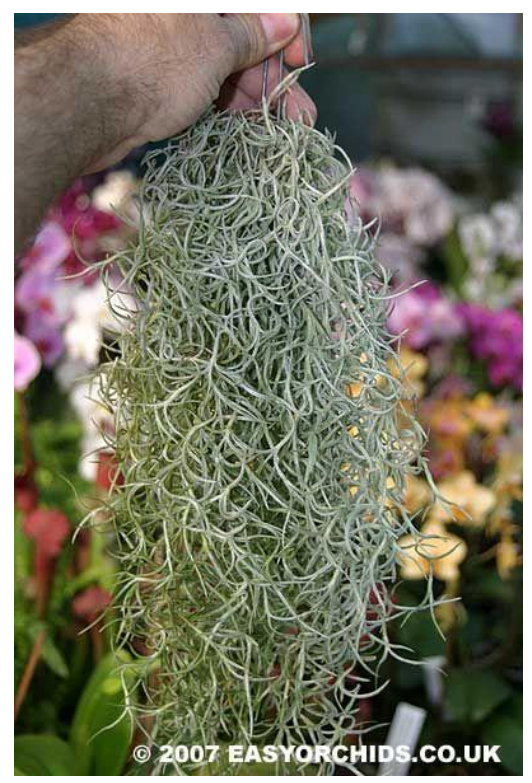

Fontes: https://pt.wikipedia.org e https://br.pinterest.com, para as fotos (a) e (b), respectivamente. 
No caso das bromélias, também foram analisadas amostras cedidas por colegas do IPEN, recebidas na forma de pó. Na Tabela 4 encontra-se a lista de amostras de bromélias analisadas neste trabalho.

Tabela 4 - Dados das amostras de bromélias analisadas neste trabalho.

\begin{tabular}{|c|c|c|c|c|c|}
\hline $\begin{array}{c}\text { Código da } \\
\text { amostra }\end{array}$ & Espécie & $\begin{array}{c}\text { Data da } \\
\text { coleta }\end{array}$ & Região & Local da coleta & $\begin{array}{c}\text { Responsável } \\
\text { pela coleta }\end{array}$ \\
\hline B1 & $\begin{array}{l}\text { Tillandsia } \\
\text { recurvata }\end{array}$ & $10 / 02 / 2017$ & Butantã, SP & $\begin{array}{l}23^{\circ} 33^{\prime} 51.0^{\prime \prime S} \\
46^{\circ} 44^{\prime} 12.5^{\prime \prime} \mathrm{W}\end{array}$ & Caroline/Mitiko \\
\hline B2 & $\begin{array}{l}\text { Tillandsia } \\
\text { usneoides }\end{array}$ & $10 / 02 / 2017$ & Butantã, SP & $\begin{array}{l}23^{\circ} 33^{\prime} 51.0^{\prime \prime S} \\
46^{\circ} 44^{\prime} 12.5^{\prime \prime} \mathrm{W}\end{array}$ & Caroline/Mitiko \\
\hline B3 & $\begin{array}{l}\text { Tillandsia } \\
\text { usneoides }\end{array}$ & 09/04/2015 & $\begin{array}{l}\text { Norte do } \\
\text { Paraná, PR }\end{array}$ & $-^{*}$ & Leandro/Mitiko \\
\hline B4 & $\begin{array}{l}\text { Tillandsia } \\
\text { usneoides }\end{array}$ & 07/08/2015 & Butantã, SP & $\begin{array}{l}23^{\circ} 33^{\prime} 51.0^{\prime \prime S} \\
46^{\circ} 44^{\prime} 12.5^{\prime \prime} \mathrm{W}\end{array}$ & Leandro/Mitiko \\
\hline
\end{tabular}

* Não disponível

Fonte: autora da dissertação.

\subsection{Pesagem dos materiais de referência certificados e das amostras de biomonitores para a análise}

Pesou-se entre $150 \mathrm{mg}$ e $200 \mathrm{mg}$ de cada um dos materiais (materiais de referência certificados e amostras de biomonitores) em invólucros de polietileno usando uma balança analítica da marca Shimadzu com precisão de 0,00001 g. Esses invólucros de polietileno foram preparados utilizando folhas de polietileno previamente desmineralizadas com uma solução de ácido nítrico p.a. diluído e água purificada Milli- $Q$, seguida de secagem a temperatura ambiente.

O invólucro de polietileno vazio foi pesado e o material a ser utilizado foi adicionado em seu interior, seguido de outra pesagem. A diferença entre as massas do invólucro vazio e cheio representa a massa do material de referência certificado ou da amostra presente no invólucro. Concluída a pesagem, esse invólucro foi selado, com o auxílio de uma seladora elétrica e de uma folha de celofane e, por fim, o material pesado foi identificado. 
A fim de se avaliar qual seria o melhor invólucro para irradiação do $\mathrm{Hg}$, ou seja, o que evita perda desse por elemento volatilização, utilizou-se também cápsulas de polietileno de alta pureza do tipo W da Vrije Universiteit, Amsterdam para irradiação de materiais de referência certificados. As características das cápsulas utilizadas estão listadas abaixo:

- Material da cápsula: polietileno de alta densidade;

- Capacidade: $0,5 \mathrm{~cm}^{3}$;

- Massa: $220 \mathrm{mg}$;

- Diâmetro interno: 8 mm;

- Diâmetro externo: 9,3 mm;

- Altura interna: $11,4 \mathrm{~mm}$;

- Altura externa: $12,4 \mathrm{~mm}$.

O material pesado ocupou cerca de $2 / 3$ do volume total da cápsula, para evitar o eventual inchamento com a formação de gases durante a irradiação. A cápsula contendo o material pesado foi tampada e selada com um ferro elétrico para solda.

\subsection{Determinação de umidade dos materiais de referência certificados e das amostras de biomonitores}

A determinação de umidade residual dos materiais de referência certificados e das amostras de biomonitores foi realizada com a finalidade de se obter a fração mássica dos elementos na base seca de cada material.

Para isso, pesou-se um pesa-filtro vazio, em que posteriormente pesou-se cerca de $250 \mathrm{mg}$ do material para secagem. Esse pesa-filtro foi colocado em uma estufa e a temperatura de secagem foi de cerca de $85 \stackrel{\circ}{\circ} \mathrm{C}$, por um período de 1 a 2 dias ou até se obter massa constante. Feito isso, o pesa-filtro com o material seco foi pesado novamente. A massa de água é a diferença entre as massas da amostra antes e depois da secagem.

Tendo a massa de umidade perdida na secagem, foi calculada a porcentagem de umidade do material. As porcentagens de umidade obtidas foram 
utilizadas no cálculo das concentrações dos elementos na base seca. Essa determinação de umidade foi realizada para todos os materiais de referência certificados e amostras de biomonitores utilizados neste estudo.

Nas Tabela 5 e 6 estão os resultados da determinação de umidade dos MRCs e das amostras de biomonitores, respectivamente.

Tabela 5 - Porcentagens de umidade determinadas nos materiais de referência certificados (MRCs) utilizados.

\begin{tabular}{cc}
\hline Materiais de referência certificados & Umidade, \% \\
\hline INCT TL-1 Tea Leaves & 4,13 \\
IAEA 336 Trace and minor elements in lichen & 8,48 \\
BCR 482 Trace elements in lichen & 7,93 \\
IAEA-085 Methylmercury, total mercury and other trace elements & 6,65 \\
$\quad$ in human hair & 6,06 \\
INCT MODAS-4 Cormorant Tissue (M-4 CormTis) & 8,82 \\
NRC DOLT-3 Dogfish Liver Certified Reference Material for Trace & 14,5 \\
Metals & 10,9 \\
BCR 1566 Pig Kidney & 5,71
\end{tabular}

Fonte: autora da dissertação. 
Tabela 6 - Porcentagens de umidade residual determinadas nas amostras de biomonitores da poluição atmosféricas analisadas.

\begin{tabular}{cr}
\hline Código da amostra & Umidade, \% \\
\hline Amostras de casca de árvore \\
C1 & 7,40 \\
C2 & 7,33 \\
C3 & 8,36 \\
C4 & 4,88 \\
C5 & 12,5 \\
C6 & 8,34 \\
C7 & 6,44 \\
C8 & 15,5 \\
C9 & 9,32 \\
C10 & 12,3 \\
C11 & 11,9 \\
C12 & 12,8 \\
& Amostra de líquen \\
L1 & 6,07 \\
Amostras de bromélias \\
B2 & 16,6 \\
B3 & 9,40 \\
B4 & 1,53 \\
& 2,09 \\
\hline
\end{tabular}

Fonte: autora de dissertação.

\subsection{Preparo dos padrões sintéticos de arsênio, cobre e mercúrio}

Para o preparo das soluções padrão diluídas de As, $\mathrm{Cu}$ e $\mathrm{Hg}$, foram utilizadas soluções padrão desses elementos certificadas da Spex CertiPrep USA, materiais volumétricos previamente verificados quanto a sua calibração e água purificada Milli-Q. Essas soluções padrão diluídas foram colocadas em frascos de polietileno da marca Nalgene e armazenadas em geladeira. 
$\mathrm{Na}$ Tabela 7 estão os elementos químicos dos padrões sintéticos utilizados nas irradiações com suas respectivas concentrações e massas.

Tabela 7 - Concentrações de elementos nas soluções utilizadas para o preparo dos padrões sintéticos e massas dos elementos irradiados.

\begin{tabular}{ccc}
\hline Elemento & Concentração $\left(\mu \mathrm{g} \mathrm{mL}^{-1}\right)$ & Massa em $50 \mu \mathrm{L}(\mu \mathrm{g})$ \\
\hline $\mathrm{As}$ & $30,000 \pm 0,090$ & $1,5000 \pm 0,0045$ \\
$\mathrm{Cu}$ & $2000 \pm 10$ & $100,00 \pm 0,50$ \\
$\mathrm{Hg}$ & $136,54 \pm 0,82$ & $6,827 \pm 0,041$ \\
\hline
\end{tabular}

Fonte: autora da dissertação.

- Preparo do padrão sintético de As e Cu:

Alíquotas de $50 \mu \mathrm{L}$ de cada uma das soluções padrão de As e $\mathrm{Cu}$ foram pipetadas sobre tiras de papel-filtro Whatman ํo 40 de dimensões aproximadas de $6 \mathrm{~cm} \times 1,5 \mathrm{~cm}$, utilizando pipetador automático da marca Eppendorf previamente verificado quanto a sua calibração. As tiras de papel contendo as alíquotas pipetadas permaneceram em dessecador por cerca de $24 \mathrm{~h}$ para a secagem das soluções pipetadas. Posteriormente, essas tiras foram cortadas em suas bases, dobradas e colocadas em invólucros de polietileno, os quais foram selados. Na Figura 8, invólucros contendo os padrões sintéticos pipetados são mostrados.

- Preparo do padrão sintético de Hg:

No caso da preparação do padrão de $\mathrm{Hg}$, antes de se pipetar a solução padrão desse elemento, pipetou-se $50 \mu \mathrm{L}$ de uma solução de tioacetamida $8 \mathrm{mg}$ $\mathrm{mL}^{-1}$ sobre cada tira de papel filtro. Para o preparo dessa solução, uma massa de 195 mg de tioacetamida p.a. da marca Merck foi pesada e dissolvida em água Milli-Q, avolumando-se a solução resultante em um balão volumétrico de $25 \mathrm{~mL}$. A tioacetamida minimiza a perda do mercúrio por volatilização, uma vez que o enxofre presente em sua estrutura reage com o $\mathrm{Hg}$, levando à formação de $\mathrm{HgS}$ (TAKEUCHI et al, 1979; PATTERSON e PASSIVO, 1987). As tiras com tioacetamida permaneceram em dessecador por cerca de $24 \mathrm{~h}$ para sua secagem 
e então $50 \mu \mathrm{L}$ da solução padrão de $\mathrm{Hg}$ foi pipetada sobre elas. Após a secagem, as tiras foram dobradas e colocadas nos invólucros de polietileno, os quais foram selados.

Também foram preparados padrões sintéticos de $\mathrm{Hg}$ em cápsulas de polietileno do tipo W (Vrije Univesiteit, Amsterdam, The Nertherlands). Para a preparação desses padrões, pequenas tiras de papel-filtro Whatman ㄲo. 40 foram inicialmente colocadas dentro das cápsulas. Essas tiras de papel foram colocadas nas cápsulas para se obter a amostra e o padrão na mesma geometria. Feito isso, o preparo seguiu da mesma forma que descrito para os padrões desse elemento preparados em invólucros de polietileno.

Os padrões sintéticos de $\mathrm{Hg}$ ficaram armazenados em geladeira até o seu uso.

Figura 8 - Fotografia de invólucros de polietileno contendo padrões sintéticos de As, $\mathrm{Cu}$ e Hg.

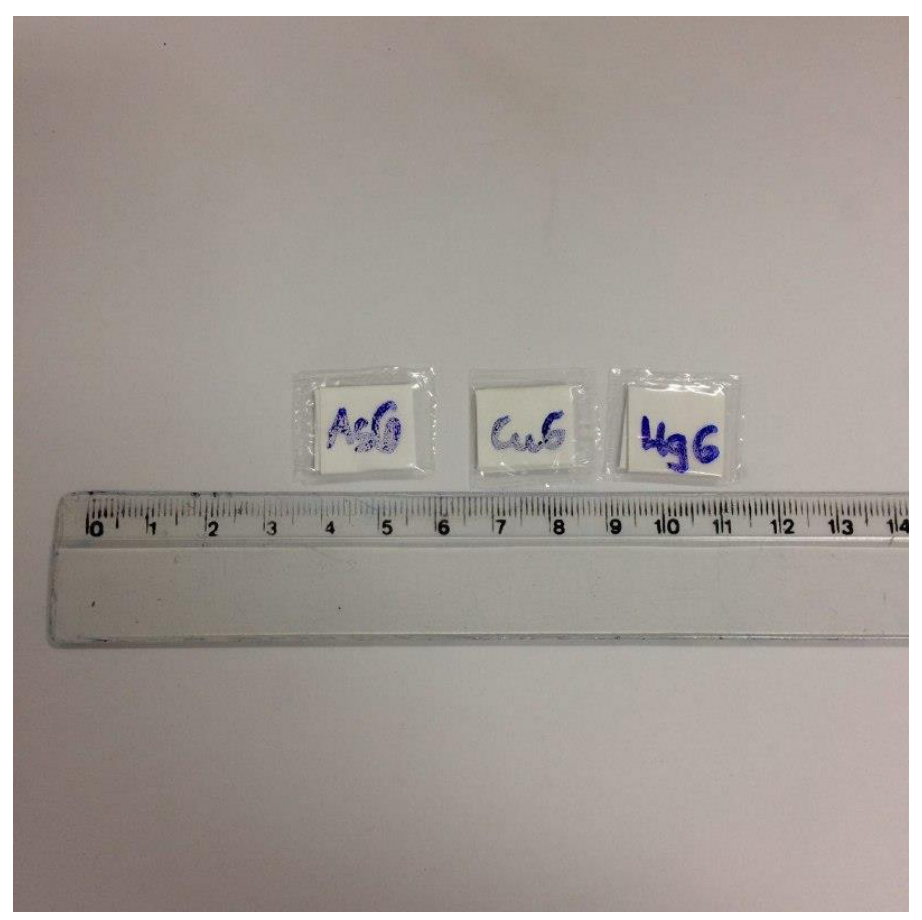

Fonte: autora da dissertação. 


\subsection{Procedimento dos ensaios preliminares}

5.5.1 Determinação de arsênio, cobre e mercúrio nos invólucros de polietileno e nas tiras de papel filtro utilizados para irradiação

Como, para as contagens, as amostras não são removidas dos invólucros de polietileno utilizados na irradiação, foi feita a determinação de As, $\mathrm{Cu}$ e $\mathrm{Hg}$ nesses invólucros, para verificar se as impurezas desses elementos não estariam interferindo nas análises.

Foram analisados invólucros vazios pelos mesmos procedimentos de irradiação que as amostras foram submetidas para análise, descritos no item 5.6 desta dissertação. As dimensões dos invólucros de polietileno analisados foram de aproximadamente $1,5 \times 1,5 \mathrm{~cm}$ e suas massas variaram de 0,02659 a 0,02901 g.

Foram realizadas irradiações de $20 \mathrm{~s}, 1 \mathrm{~h}$ e $8 \mathrm{~h}$, em que os invólucros foram irradiados juntamente aos padrões dos elementos. Após as irradiações, as atividades gama dos invólucros e padrões foram medidas.

$\mathrm{O}$ mesmo procedimento utilizado para determinação de $\mathrm{As}, \mathrm{Cu}$ e $\mathrm{Hg}$ nos invólucros de polietileno foi aplicado para análise da tira de papel-filtro Whatman nํ. 40, usada como suporte na preparação dos padrões sintéticos. Para esse estudo, amostras do papel-filtro foram cortadas exatamente como as tiras utilizadas para o preparo dos padrões, pesadas, dobradas com o auxílio de pinças e colocadas em invólucros de polietileno, que foram posteriormente selados. As dimensões das tiras de papel filtro analisadas foram de aproximadamente $1,5 \mathrm{x}$ $6,0 \mathrm{~cm}$ e suas massas variaram de 0,12030 a $0,12607 \mathrm{~g}$.

\subsubsection{Escolha das condições para a determinação de arsênio}

Para a escolha do tempo de irradiação mais adequado para a determinação de As pela NAA, quantificou-se esse elemento nos MRCs IAEA-336 Trace and minor elements in lichen e BCR 482 Trace elements in lichen fazendo 
irradiações de 1 e 8 h. A partir dos resultados obtidos, fez-se a escolha do tempo de irradiação.

Foram feitas as medições para dois tempos de decaimento diferentes e os cálculos foram realizados para os picos de energia de raios gama de 559,10 keV e 657,05 keV.

5.5.3 Escolha das condições de irradiação para a determinação de cobre

O Cu pode ser determinado pela medida do ${ }^{66} \mathrm{Cu}\left(\mathrm{t}_{1 / 2}=5,10 \mathrm{~min}\right)$ ou do ${ }^{64} \mathrm{Cu}\left(\mathrm{t}_{1 / 2}=12,7 \mathrm{~h}\right)$.

Pela análise dos MRCs verificou-se preliminarmente que o $\mathrm{Cu}$ pode ser determinado por meio de irradiações de $20 \mathrm{~s}$ e de $1 \mathrm{~h}$. Não foi possível determinar esse elemento por meio de irradiações de $8 \mathrm{~h}$, uma vez que, nesse caso, as medidas só poderiam ser iniciadas após cerca de 3 dias de decaimento, ou seja, após cerca de 6 meias-vidas de decaimento do ${ }^{64} \mathrm{Cu}\left(\mathrm{t}_{1 / 2}=12,7 \mathrm{~h}\right)$. A alta atividade da amostra impediu a realização das medidas com menor tempo de decaimento, bem como a alta atividade do ${ }^{24} \mathrm{Na}\left(\mathrm{t}_{1 / 2}=14,96 \mathrm{~h}\right)$ impediu, muitas vezes, a detecção do pico do ${ }^{64} \mathrm{Cu}$.

5.5.4 Escolha do tempo e do recipiente para irradiação para a determinação de $\mathrm{Hg}$

As condições adequadas para a determinação de $\mathrm{Hg}$ foram estabelecidas fazendo-se a análise do MRC IAEA-085 Human hair. Para isso, alíquotas desse MRC e padrões sintéticos de $\mathrm{Hg}$ foram irradiados por 1 e $8 \mathrm{~h}$ em invólucro de polietileno e por $1 \mathrm{~h}$ em cápsula de polietileno. As medidas das atividades de ${ }^{197} \mathrm{Hg}$ e ${ }^{203} \mathrm{Hg}$ foram realizadas em diferentes tempos de decaimento. A perda de $\mathrm{Hg}$ durante a irradiação foi avaliada pela comparação dos resultados de fração mássica de $\mathrm{Hg}$ obtidos na análise do MRC e o valor do certificado. Para avaliar se houve perda de $\mathrm{Hg}$ após a irradiação, as taxas de contagens do padrão de $\mathrm{Hg}$ foram obtidas para diferentes tempos de decaimento. 
No caso, esse padrão sintético foi mantido na sala de contagens a uma temperatura de cerca de $21^{\circ} \mathrm{C}$.

\subsection{Procedimento de NAA para a análise}

Os procedimentos descritos neste item referem-se àqueles nos quais as condições experimentais foram definidas por meio dos ensaios preliminares.

5.6.1 Procedimento para irradiações de longa duração no reator nuclear para a determinação de arsênio, cobre e mercúrio

Para a determinação dos elementos $\mathrm{As}, \mathrm{Cu}$ e $\mathrm{Hg}$ por meio da irradiação de longa duração (tempo de irradiação na ordem de horas), embrulharam-se individualmente as amostras e os padrões contidos em invólucros de polietileno em folha de alumínio. Esse conjunto de amostras e padrões foi envolto em uma nova folha alumínio e colocado em um dispositivo para irradiação de longa duração conhecido como "coelho", que consiste em um cilindro de alumínio (Figura 9). Para a irradiação, esse "coelho" foi lacrado com uma tampa, que foi soldada pelo Pessoal do Serviço de Irradiação do reator. As irradiações foram realizadas no reator nuclear de pesquisa IEA-R1 do IPEN CNEN/SP, sob fluxo de nêutrons térmicos de $4,2 \times 10^{12}$ a $4,6 \times 10^{12} \mathrm{n} \mathrm{cm}^{-2} \mathrm{~s}^{-1}$ por 1 ou 8 horas, dependendo do elemento a ser determinado. 
Figura 9 - Fotografia do dispositivo de alumínio ("coelho") de dimensões 7,0 × 2,1 $\mathrm{cm}$ utilizado nas irradiações de longa duração.

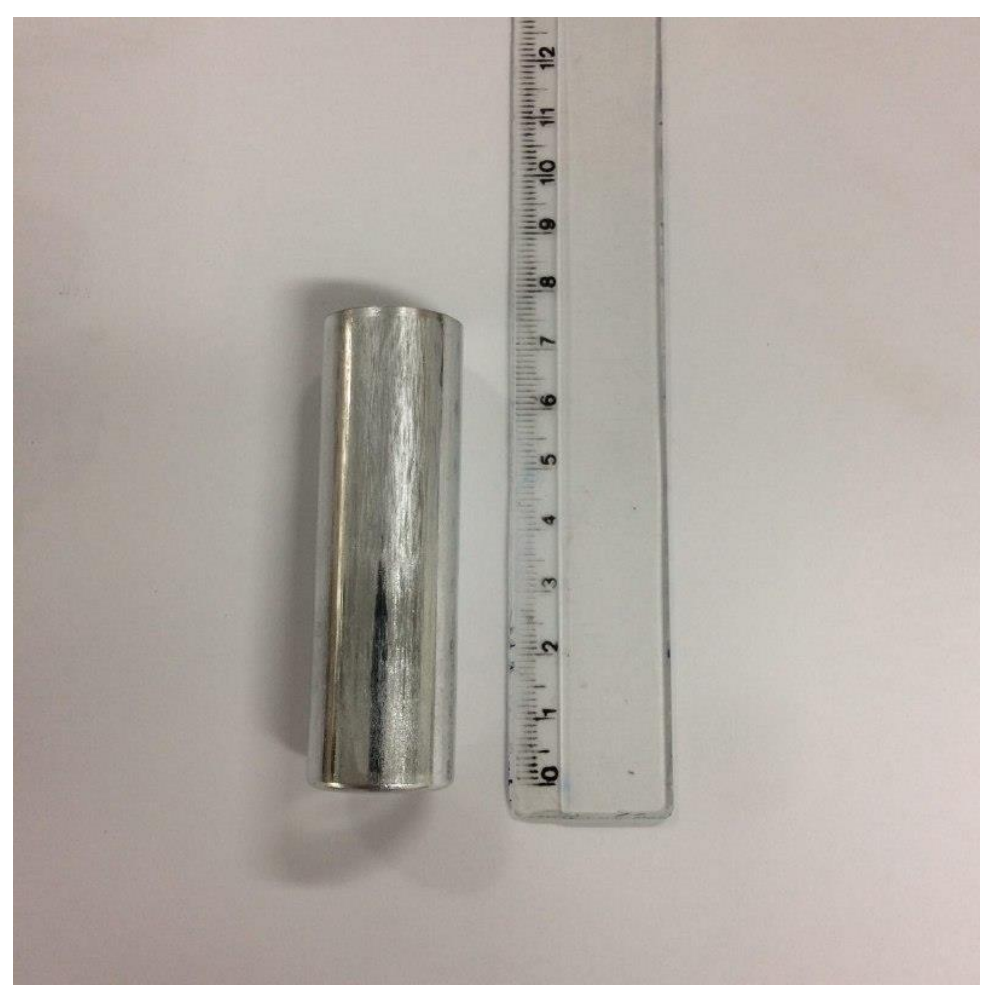

Fonte: autora da dissertação.

Para as medições das atividades gama, as amostras e padrões foram retirados do "coelho" sob a supervisão do Pessoal da Proteção Radiológica. Esses procedimentos de abertura do "coelho" e as contagens foram realizados 1 dia após a irradiação, no caso das irradiações de 1 h, e 3 d após a irradiação, para as irradiações de $8 \mathrm{~h}$. Feito isso, as amostras e os padrões foram fixados individualmente em suportes de aço inoxidável conhecidos como "panelinhas" (Figura 10) utilizando-se fita gomada devidamente identificada com o nome do padrão ou da amostra. 
Figura 10 - Fotografia de suporte de aço inoxidável ("panelinha") com $3 \mathrm{~cm}$ de diâmetro.

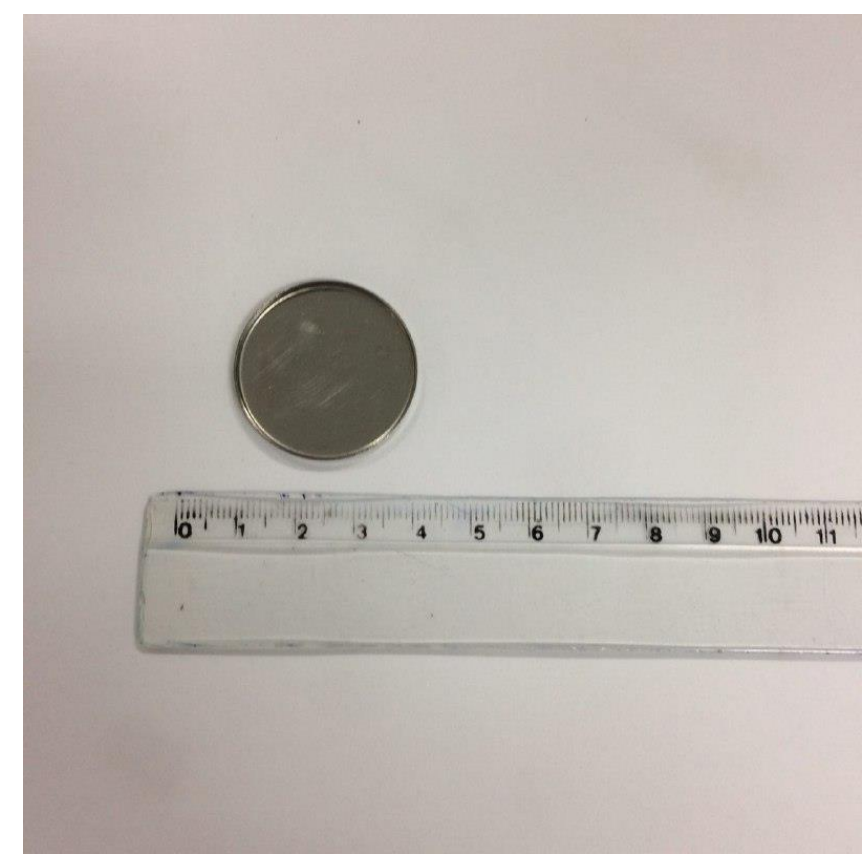

Fonte: autora da dissertação.

No caso da determinação de Hg usando cápsulas para a irradiação, as cápsulas de padrão de $\mathrm{Hg}$ e de amostras foram individualmente embrulhadas em folha de alumínio e depois embrulhadas juntas em outra folha de alumínio. 0 conjunto de amostra e padrão foi colocado no "coelho", que foi lacrado e irradiado pelo mesmo procedimento descrito para irradiações em invólucro de polietileno. Para a realização das medidas das atividades gama, o "coelho" foi aberto cerca de 1 dia após a irradiação sob a supervisão do Pessoal da Proteção Radiológica. As cápsulas foram colocadas individualmente em tubos de contagem de plástico para as medições. Para se evitar a mobilidade da cápsula dentro do tubo, utilizouse um chumaço de algodão.

As medições das atividades gama foram realizadas utilizando-se um detector semicondutor de germânio hiperpuro da marca Canberra modelo GC3020, ligado a um analisador digital de espectro DSA 1000, também da marca Canberra, e a um microcomputador. Para verificar o funcionamento do sistema de contagens, diariamente, antes de se iniciar as medições, foi feita a contagem de uma fonte de ${ }^{57} \mathrm{Co}+{ }^{60} \mathrm{Co}$. A resolução (FWHM) do sistema utilizado foi de 0,90 
keV para o pico de $121,97 \mathrm{keV}$ do ${ }^{57} \mathrm{Co}$ e de $1,70 \mathrm{keV}$ para o pico de $1332,49 \mathrm{keV}$ do ${ }^{60} \mathrm{Co}$.

Para as contagens, realizou-se a escolha adequada da distância entre a amostra e o detector, de maneira que a porcentagem de tempo morto não ultrapassasse $10 \%$. A aquisição e o processamento dos espectros foram feitos usando o programa Genie 2000 versão 3.1 da Canberra. A partir do processamento, obtiveram-se os dados das taxas de contagem e energias de raios gama. Os tempos de contagem variaram de 1800 a 5400 s para os padrões, e de 3600 a 36000 s para as amostras, dependendo de suas atividades.

5.6.2 Procedimento para irradiações de curta duração no reator nuclear para a determinação de cobre

A determinação de Cu por meio da medida do ${ }^{66} \mathrm{Cu}$ foi feita por meio de irradiações de curta duração (tempo de irradiação na ordem de segundos). Para isso, a amostra e o padrão sintético de cobre, contidos em invólucros de polietileno, foram colocados em um novo invólucro de polietileno maior, o qual foi inserido em um dispositivo de polietileno para irradiação de curta duração, também conhecido como "coelho" (Figura 11). 
Figura 11 - Fotografia do dispositivo de polietileno ("coelho") de dimensões 5,6 x 2,3 cm utilizado nas irradiações de curta duração.

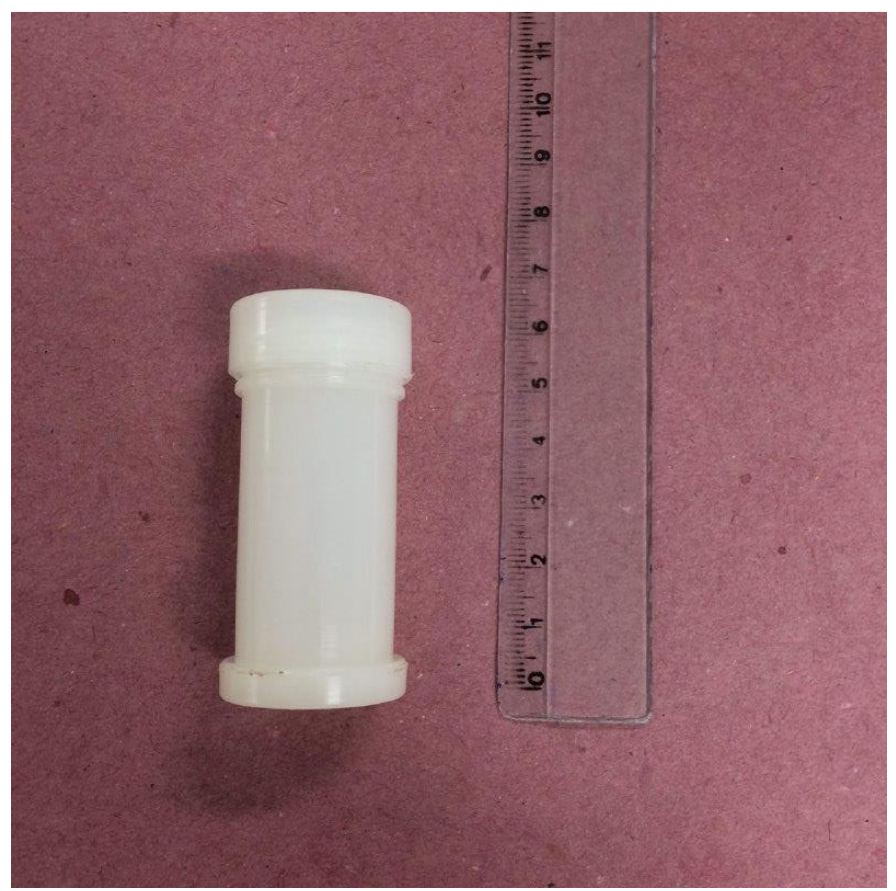

Fonte: autora da dissertação.

O "coelho" de polietileno contendo a amostra e o padrão foi submetido a 20 s de irradiação na Estação Pneumática no 4 (Figura 12) do reator nuclear de pesquisas IEA-R1 sob um fluxo de nêutrons térmicos de $1,9 \times 10^{12} \mathrm{n} \mathrm{cm}^{-2} \mathrm{~s}^{-1}$. Um cronômetro foi utilizado para se registrar os tempos final da irradiação e inicial e final de medição para correção das atividades para o mesmo tempo de decaimento. As atividades gama da amostra e padrão foram medidas por $300 \mathrm{~s}$, após cerca de 5 min de decaimento, no mesmo sistema de medição utilizado nas irradiações de longa duração. 
Figura 12 - Fotografia da Estação Pneumática №. 4 do reator nuclear de pesquisas IEA-R1.

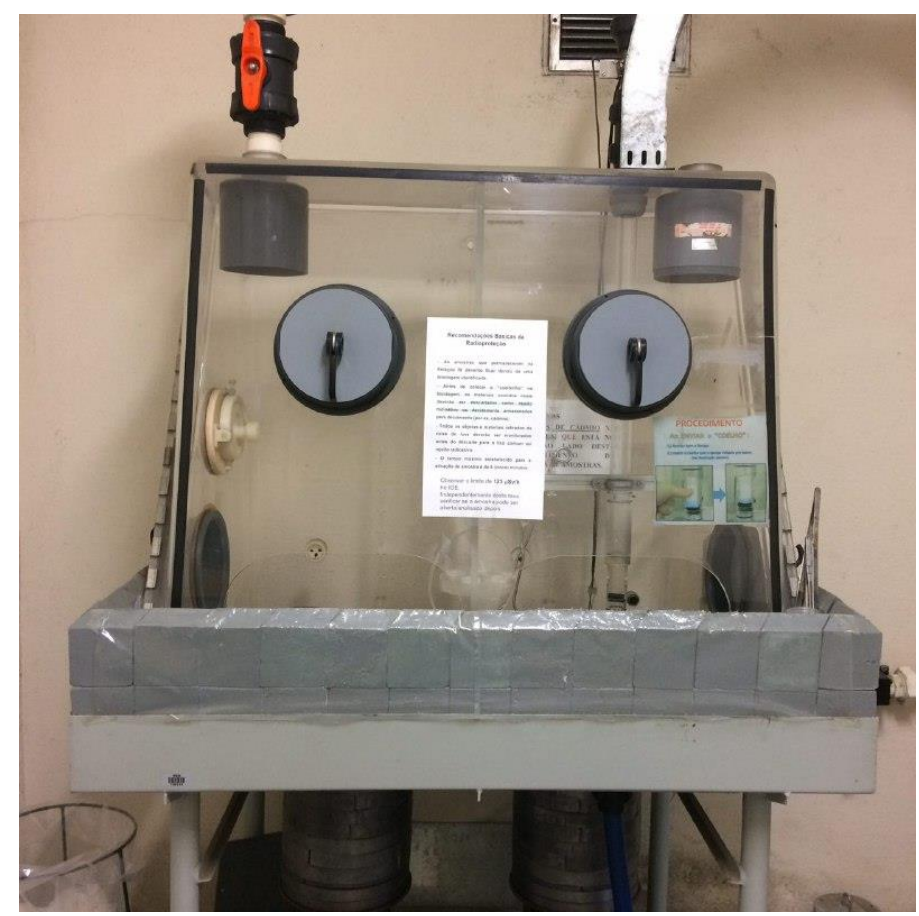

Fonte: autora da dissertação.

5.6.3 Identificação dos radionuclídeos e cálculo das frações mássicas

A identificação dos radionuclídeos dos espectros de raios gama foi feita pelas energias de raios gama e pela meia-vida, consultando os dados nucleares do relatório da Agência Internacional de Energia Atômica (IAEA, 1990). As concentrações ou frações mássicas foram calculadas pelo método comparativo, utilizando-se a relação (3.10).

$\mathrm{Na}$ Tabela 8, as condições de irradiação e medição utilizadas neste trabalho para a determinação de $\mathrm{As}, \mathrm{Cu}$ e $\mathrm{Hg}$ pela NAA estão sumarizadas, juntamente aos tempos de meia-vida e às energias de raio gama dos radionuclídeos medidos. 
Tabela 8 - Dados nucleares e condições de irradiação utilizadas para a determinação de arsênio, cobre e mercúrio neste trabalho.

\begin{tabular}{|c|c|c|c|c|c|c|}
\hline Elemento & $\begin{array}{l}\text { Tempo de } \\
\text { irradiação }\end{array}$ & $\begin{array}{l}\text { Fluxo de } \\
\text { nêutrons } \\
\text { térmicos, } \\
\mathrm{n} \mathrm{cm}^{-2} \mathrm{~s}^{-1}\end{array}$ & $\begin{array}{l}\text { Tempo de } \\
\text { decaimento }\end{array}$ & $\begin{array}{l}\text { Radionuclídeo medido (Energia dos raios } \\
\left.\qquad \text { gama, } k e V \text { e } t_{1 / 2}\right)\end{array}$ & $\begin{array}{c}\text { Tempo de } \\
\text { contagem da } \\
\text { amostra, s }\end{array}$ & Observação \\
\hline \multirow[b]{2}{*}{ As } & $1 \mathrm{~h}$ & \multirow{2}{*}{$\begin{array}{c}4,2 \times 10^{12} \text { a } 4,6 \times \\
10^{12}\end{array}$} & $1-2 d$ & \multirow{2}{*}{$\begin{array}{c}{ }^{76} \mathrm{As}(559,10 \mathrm{keV}, 657,05 \mathrm{keV} \\
\left.\mathrm{t}_{1 / 2}=26,32 \mathrm{~h}\right)\end{array}$} & \multirow[t]{2}{*}{$20000-36000$} & $\sqrt{ }^{*}$ \\
\hline & $8 \mathrm{~h}$ & & $3-4 d$ & & & $\checkmark$ \\
\hline \multirow[b]{3}{*}{$\mathrm{Cu}$} & $20 \mathrm{~s}$ & $1,9 \times 10^{12}$ & $5 \min$ & ${ }^{66} \mathrm{Cu}\left(1039,20 \mathrm{keV} ; \mathrm{t}_{1 / 2}=5,10 \mathrm{~min}\right)$ & 300 & $\checkmark$ \\
\hline & $1 \mathrm{~h}$ & \multirow[b]{2}{*}{$\begin{array}{c}4,2 \times 10^{12} \text { a } 4,6 x \\
10^{12}\end{array}$} & $1-2 d$ & \multirow[b]{2}{*}{${ }^{64} \mathrm{Cu}\left(1345,77 \mathrm{keV} ; \mathrm{t}_{1 / 2}=12,7 \mathrm{~h}\right)$} & \multirow[b]{2}{*}{$20000-36000$} & $\checkmark$ \\
\hline & $8 \mathrm{~h}$ & & $3 d$ & & & $\begin{array}{l}\text { Dependendo da } \\
\text { amostra, altas } \\
\text { atividades do }{ }^{24} \mathrm{Na} \\
\text { podem afetar a } \\
\text { detecção do }{ }^{64} \mathrm{Cu}\end{array}$ \\
\hline \multirow[b]{2}{*}{$\mathrm{Hg}$} & $1 \mathrm{~h}$ & \multirow[b]{2}{*}{$\begin{array}{c}4,2 \times 10^{12} \text { a } 4,6 x \\
10^{12}\end{array}$} & $1-6 d$ & \multirow[b]{2}{*}{$\begin{aligned} &{ }^{197} \mathrm{Hg}\left(77,34 \mathrm{keV} ; \mathrm{t}_{1 / 2}\right.=64,1 \mathrm{~h}) ; \\
&{ }^{203} \mathrm{Hg}\left(279,20 \mathrm{keV} ; \mathrm{t}_{1 / 2}=46,61 \mathrm{~d}\right)\end{aligned}$} & $3600-36000$ & $\checkmark$ \\
\hline & $8 \mathrm{~h}$ & & $3-7 d$ & & $20000-36000$ & $\begin{array}{c}\text { Dependendo da } \\
\text { amostra, pode } \\
\text { ocorrer interferências } \\
\text { espectrais do }{ }^{198} \mathrm{Au} \text { e } \\
\text { do }{ }^{75} \mathrm{Se}\end{array}$ \\
\hline
\end{tabular}

$* \sqrt{ }$ indica que não houve problema na determinação do elemento para a maioria dos MRCs.

Fonte: autora da dissertação. 


\subsection{Tratamento dos dados obtidos}

Para a avaliação dos resultados de frações mássicas dos elementos obtidos nos materiais de referência certificados e nas amostras de biomonitores da poluição atmosférica, calculou-se os parâmetros de média aritmética, desvio padrão, desvio padrão relativo, valor HORRAT. Além disso, para os MRCs, para a análise da exatidão, foram calculados erro relativo percentual e diferença padronizada ou Z score (HORWITZ e ALBERT, 2006; KONIECZKA e NAMIESNIK, 2016).

\subsubsection{Avaliação da precisão dos resultados}

A precisão dos resultados foi avaliada segundo Wood (1999), que considera que esse parâmetro está relacionado com o nível de concentração (ou fração mássica) do analito na amostra e é definido pela equação de Horwitz (HORWITZ e ALBERT, 2006), dada por:

$$
\mathrm{DPR}_{\mathrm{H}}=2^{(1-0,5 \log \mathrm{c})}
$$

Em que $\mathrm{DPR}_{H}$ é o valor de Horwitz e c é fração mássica do analito expressa da seguinte forma: se a fração mássica é de $1 \mathrm{mg} \mathrm{kg}^{-1}$, por exemplo, $\mathrm{C}=$ $1 \times 10^{-6}$.

A avaliação da precisão do método é feita pelo valor de HORRAT, dado por:

$$
\text { HORRAT }=\frac{\text { DPR }}{D_{\text {PRR }}}
$$

Em que DPR é o desvio padrão relativo obtido experimentalmente. 
O método é considerado preciso quando o valor de HORRAT é menor ou igual a 2 (WOOD, 1999).

\subsubsection{Diferença padronizada (Z score)}

O cálculo dos valores de $Z$ score obtidos dos resultados das análises dos materiais de referência certificados foi realizado utilizando-se a relação (5.3) (KONIECZKA e NAMIESNIK, 2016), em que Xlab é a fração mássica obtida em

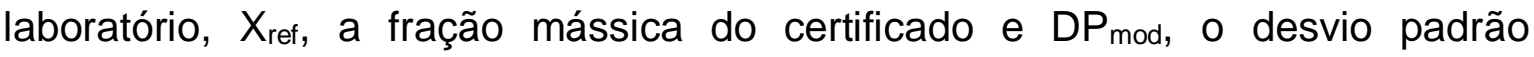
modificado, obtido por meio da relação (5.4) (KONIECZKA e NAMIESNIK, 2016).

$$
\begin{aligned}
& \mathrm{Z} \text { score }=\frac{\mathrm{X}_{\mathrm{lab}}-\mathrm{X}_{\mathrm{ref}}}{\mathrm{DP}_{\mathrm{mod}}} \\
& \mathrm{DP}_{\text {mod }}=\sqrt{\mathrm{DP}^{2}+\mathrm{u}_{\mathrm{Xref}}^{2}}
\end{aligned}
$$

Em que DP é o desvio padrão das medidas obtidas no laboratório e uxref é a incerteza combinada do valor certificado de referência. O resultado é classificado como satisfatório ou insatisfatório de acordo com o seguinte critério (KONIECZKA e NAMIESNIK, 2016):

Se $\mid Z$ score $\mid \leq 2$, o resultado é considerado satisfatório.

Se $2<\mid Z$ score $\mid<3$, o resultado é considerado incerto.

Se $\mid Z$ score $\mid \geq 3$, o resultado é considerado insatisfatório. 
5.7.3 Cálculo dos limites de detecção e de quantificação

O limite de detecção é definido como a menor concentração (fração mássica) do analito que pode ser detectada pelo método, enquanto o limite de quantificação (ou determinação) é definido como a menor fração mássica que pode ser quantificada com precisão e incerteza (INMETRO, 2010). Para o cálculo dos limites de detecção e de quantificação dos elementos na análise por ativação com nêutrons (NAA) em taxas de contagens (LDT e LQT, respectivamente), utilizou-se o critério de Currie e as seguintes relações (CURRIE, 1999):

$$
\begin{aligned}
& \mathrm{LDT}=3,29 \frac{\sqrt{\mathrm{BG}}}{\mathrm{LT}} \\
& \mathrm{LQT}=10 \frac{\sqrt{\mathrm{BG}}}{\mathrm{LT}}
\end{aligned}
$$

Em que BG ("background") é a taxa de contagem da radiação de fundo ou área sob o pico e LT, o tempo de contagem. O valor do BG foi obtido a partir da saída de dados do processamento dos espectros gama.

Uma vez obtidos os valores de LDT e LQT, os limites de detecção (LD) e de quantificação (LQ) em frações mássicas dos elementos foram calculados pelo método comparativo. 


\section{RESULTADOS E DISCUSSÃO}

Nesse Capítulo, serão apresentados e discutidos os resultados obtidos neste trabalho, seguindo a seguinte sequência:

- Resultados da determinação de As, $\mathrm{Cu}$ e $\mathrm{Hg}$ nos invólucros de polietileno e nas tiras de papel-filtro;

- Resultados da determinação de As para estabelecimento de condições experimentais e nas análises de MRCs e biomonitores;

- Resultados da determinação de Cu em MRCs e em amostras de biomonitores;

- Resultados da determinação de $\mathrm{Hg}$ para estabelecimento de condições experimentais e nas análises de MRCs e biomonitores.

\subsection{Resultados da determinação de arsênio, cobre e mercúrio nos invólucros de polietileno e nas tiras de papel-filtro.}

A presença de As, Cu e $\mathrm{Hg}$ foi examinada nos invólucros de polietileno utilizados para irradiação e nas tiras de papel-filtro, uma vez que a contribuição das impurezas desses elementos nesses materiais poderia afetar os resultados das análises. Os resultados das massas obtidas nesses materiais estão na Tabela 9 , juntamente às massas dos elementos em $150 \mathrm{mg}$ de um MRC e às massas dos elementos presentes nos padrões pipetado.

Para avaliar se as quantidades dos $\mathrm{As}, \mathrm{Cu}$ e $\mathrm{Hg}$ nesses materiais estariam interferindo nas análises, foram calculadas as massas desses elementos presentes em $150 \mathrm{mg}$ do MRC INCT M-4 Cormorant tissue, que apresenta baixos teores de As, Cu e Hg. 
Tabela 9 - Massas de arsênio, cobre e mercúrio no invólucro de polietileno, na tira de papel-filtro, na amostra de material de referência e no padrão sintético.

\begin{tabular}{c|cccc}
\hline \multirow{2}{*}{ Elemento } & \multicolumn{4}{|c}{ Massa $(\mu \mathrm{g})$} \\
\cline { 2 - 5 } & Invólucro & Papel-filtro & Amostra $^{*}$ & Padrão \\
\hline $\mathrm{As}$ & $<0,0015$ & $\sim 0,0019$ & 0,018 & 1,5 \\
$\mathrm{Cu}$ & $<0,7$ & $<0,4$ & 2,92 & 100,0 \\
$\mathrm{Hg}$ & $\sim 0,0027$ & $0,0050-0,0084$ & 0,33 & 6,827 \\
\hline
\end{tabular}

${ }^{*}$ Massas de As, Cu e Hg em 150 mg do MRC INCT M-4 Cormorant tissue. Fonte: autora da dissertação.

Conforme mostrado na Tabela 9, o As não foi detectado no invólucro de polietileno tanto nas irradiações de $1 \mathrm{~h}$, como nas de $8 \mathrm{~h}$. Desta forma, a contribuição da impureza desse elemento no invólucro de polietileno na determinação de As foi considerada desprezível. Os seus limites de detecção obtidos variaram de 0,0002 a 0,0015 $\mu$ g por invólucro. Nas análises das tiras de papel-filtro ${ }_{2}$ foram obtidas massas de As em torno de 0,0019 $\mu \mathrm{g}$ por tira, por meio das irradiações de 1 e $8 \mathrm{~h}$. Como a massa de As no padrão sintético é muito superior às massas encontradas na tira de papel-filtro, a contribuição das impurezas desse elemento nas tiras foi também considerada desprezível.

Como as impurezas de Cu não foram detectadas no invólucro e nem na tira de papel-filtro em nenhuma das condições de tempo de irradiação $(20 \mathrm{~s}, 1$ h e 8 h) utilizadas, a contribuição desse elemento oriunda desses materiais foi considerada desprezível. No invólucro de polietileno, os limites de detecção obtidos foram entre 0,09 e 0,7 $\mu \mathrm{g}$ por invólucro. Já na tira de papel filtro, os limites de detecção variaram de 0,06 a $0,4 \mu \mathrm{g}$ por tira de papel-filtro.

No caso do $\mathrm{Hg}$, uma massa de 0,002718 $\pm 0,000085 \mu \mathrm{g}$ desse elemento por invólucro foi encontrada na irradiação de $8 \mathrm{~h}$ do invólucro, pela medida do pico de energia de raios gama de $77,34 \mathrm{keV}$ do ${ }^{197} \mathrm{Hg}$. Nas tiras de papel-filtro, as massas obtidas desse elemento variaram de 0,0050 a $0,0084 \mu \mathrm{g}$. A quantidade de $\mathrm{Hg}$ presente nos invólucros e nas tiras de papel-filtro é muito baixa. Nesse caso, a contribuição do $\mathrm{Hg}$ presente nesses materiais também foi considerada desprezível. 
Os resultados mostraram que as contribuições de $\mathrm{As}$, $\mathrm{Cu}$ e $\mathrm{Hg}$ presente no invólucro de polietileno e na tira de papel-filtro podem ser consideradas desprezíveis, uma vez que as quantidades desses elementos nas amostras e nos padrões são muito superiores às encontradas nos materiais analisados.

\subsection{Resultados da determinação de arsênio}

\subsubsection{Escolha das condições para a determinação de arsênio}

Para escolher o tempo de irradiação mais adequado para a determinação de As, determinou-se esse elemento nos MRCs IAEA-336 Trace and minor elements in lichen e BCR 482 Trace elements in lichen por meio de irradiações de 1 e 8 h. Na Tabela 10, estão apresentados os resultados (valores médios de frações mássicas, desvios padrão, desvios padrão relativos, valores de HORRAT, erros relativos e valores de Z score) dessas determinações, calculados pelos picos de energia de raios gama de 559,10 keV e 657,05 keV e em dois tempos de decaimento: 1 e $2 \mathrm{~d}$, para as determinações realizadas por meio de irradiações de 1 h, e 3 e 4 d, para as irradiações de 8 h. Nessa Tabela 10 são também apresentados os valores dos certificados para comparação.

Nos resultados da Tabela 10, verifica-se que os valores de desvio padrão relativo (DPR) são mais baixos para as análises realizadas por meio das irradiações de $1 \mathrm{~h}$. Além disso, os DPRs e os erros relativos (ERs) foram, de forma geral, menores para as determinações realizadas pela medida do pico de $559,10 \mathrm{keV}$ em relação as realizadas pela medida do pico de 657,05 keV, para ambos os tempos de irradiação. Em todos os casos, os valores de HORRAT e de $Z$ score obtidos indicaram que os resultados foram satisfatórios quanto a precisão e exatidão (HORRAT < 2 e $\mid Z$ score $\mid<2)$. 
Tabela 10 - Média das frações mássicas de arsênio, em $\mu \mathrm{g} \mathrm{g}^{-1}$, obtidas por meio de irradiações de 1 e $8 \mathrm{~h}$ nos materiais de referência certificados IAEA-336 Trace and minor elements in lichen e BCR 482 Trace elements in lichen.

\begin{tabular}{|c|c|c|c|c|c|c|}
\hline \multirow{3}{*}{$\begin{array}{l}\text { Material de referência } \\
\text { certificado }\end{array}$} & \multirow[t]{3}{*}{ Parâmetros avaliados } & \multicolumn{4}{|c|}{ Presente trabalho } & \multirow[t]{3}{*}{ Valor do certificado, $\mu \mathrm{g} \mathrm{g}^{-1}$} \\
\hline & & \multicolumn{2}{|c|}{$559,10 \mathrm{keV}$} & \multicolumn{2}{|c|}{$657,05 \mathrm{keV}$} & \\
\hline & & $\mathrm{td}_{1}{ }^{*}$ & $\mathrm{td}_{2}$ & $\mathrm{td}_{1}$ & $\mathrm{td}_{2}$ & \\
\hline \multicolumn{7}{|c|}{$t_{i}^{* *}=1 h$} \\
\hline \multirow{5}{*}{$\begin{array}{l}\text { IAEA-336 } \\
\text { Trace and minor } \\
\text { elements in lichen }\end{array}$} & $M \pm D P(n)$ & $0,681 \pm 0,032(4)$ & $0,659 \pm 0,028(4)$ & $0,767 \pm 0,088$ & $0,76 \pm 0,12(4)$ & $0,63(0,55-0,71)$ \\
\hline & DPR, \% & 4,7 & 4,3 & 11,4 & 15,2 & \\
\hline & HORRAT & 0,17 & 0,15 & 0,49 & 0,68 & \\
\hline & $\mathrm{ER}, \%$ & 8,0 & 4,6 & 21,8 & 20,4 & \\
\hline & Z score & 0,31 & 0,18 & 0,75 & 0,65 & \\
\hline \multirow{5}{*}{$\begin{array}{c}\text { BCR } 482 \\
\text { Trace elements in } \\
\text { lichen }\end{array}$} & $M \pm D P(n)$ & $0,794 \pm 0,066(4)$ & $0,762 \pm 0,041(4)$ & $0,895 \pm 0,065(4)$ & $0,82 \pm 0,13(4)$ & $0,85 \pm 0,07$ \\
\hline & DPR, \% & 8,4 & 5,4 & 7,2 & 15,3 & \\
\hline & HORRAT & 0,50 & 0,32 & 0,44 & 0,92 & \\
\hline & $\mathrm{ER}, \%$ & 6,6 & 10,4 & 5,3 & 3,1 & \\
\hline & Z score & $-0,63$ & $-1,2$ & 0,51 & $-0,19$ & \\
\hline \multicolumn{7}{|c|}{$t_{i}=8 \mathrm{~h}$} \\
\hline \multirow{5}{*}{$\begin{array}{l}\text { IAEA-336 } \\
\text { Trace and minor } \\
\text { elements in lichen }\end{array}$} & $M \pm D P(n)$ & $0,68 \pm 0,13(4)$ & $0,70 \pm 0,10(4)$ & $0,81 \pm 0,12(4)$ & $0,80 \pm 0,15(4)$ & $0,63(0,55-0,71)$ \\
\hline & DPR, \% & 18,8 & 12,7 & 14,7 & 18,7 & \\
\hline & HORRAT & 1,1 & 0,75 & 0,88 & 1,1 & \\
\hline & $\mathrm{ER}, \%$ & 7,6 & 11,3 & 28,6 & 27,4 & \\
\hline & Z score & 0,24 & 0,39 & 0,90 & 0,79 & \\
\hline \multirow{5}{*}{$\begin{array}{c}\text { BCR } 482 \\
\text { Trace elements in } \\
\text { lichen }\end{array}$} & $M \pm D P(n)$ & $0,824 \pm 0,082(4)$ & $0,815 \pm 0,080(4)$ & $0,886 \pm 0,103(4)$ & $0,890 \pm 0,038(4)$ & $0,85 \pm 0,07$ \\
\hline & DPR, \% & 10,0 & 9,9 & 11,6 & 4,3 & \\
\hline & HORRAT & 0,17 & 0,15 & 0,49 & 0,68 & \\
\hline & $\mathrm{ER}, \%$ & 3,0 & 4,1 & 4,3 & 4,8 & \\
\hline & Z score & $-0,25$ & $-0,34$ & 0,30 & 0,57 & \\
\hline
\end{tabular}

* Tempos de decaimento: a) para $1 \mathrm{~h}$ de irradiação - $\mathrm{td}_{1}=1$ dia; $\mathrm{td}_{2}=2$ dias; b) para $8 \mathrm{~h}$ de irradiação - td $1=3$ dias; td $2=4$ dias; ${ }^{* *} \mathrm{t}_{\mathrm{i}}$ : tempo de irradiação; $\mathrm{M}$ 土 DP: Média aritmética e desvio padrão; n: número de determinações; DPR: desvio padrão relativo; ER: erro relativo percentual.

Fonte: autora da dissertação. 
$\mathrm{Na}$ Tabela 11, os resultados de limites de detecção e de quantificação (LD e LQ, respectivamente) obtidos para esses dois MRCs são apresentados. Nota-se que os limites obtidos para os dois tempos de irradiações são da mesma ordem de grandeza.

Tabela 11 - Limites de detecção (LD) e de quantificação (LQ) de arsênio, em $\mu \mathrm{g}$ $\mathrm{g}^{-1}$, obtidos para os materiais de referência certificados IAEA-336 Trace and minor elements in lichen e BCR 482 Trace elements in lichen.

\begin{tabular}{|c|c|c|c|c|c|}
\hline \multirow[b]{2}{*}{ Material de referência certificado } & \multicolumn{2}{|c|}{$559,10 \mathrm{keV}$} & \multicolumn{2}{|c|}{$657,05 \mathrm{keV}$} & \multirow[b]{2}{*}{$\begin{array}{l}\text { Valor do } \\
\text { certificado, } \mu \mathrm{g} \mathrm{g}^{-1}\end{array}$} \\
\hline & LD & LQ & LD & LQ & \\
\hline \multicolumn{6}{|c|}{$t_{i}^{*}=1 h ; t_{d}=1 d$} \\
\hline $\begin{array}{l}\text { IAEA- } 336 \text { Trace and minor } \\
\text { elements in lichen }\end{array}$ & 0,027 & 0,082 & 0,22 & 0,66 & $0,63(0,55-0,71)$ \\
\hline $\begin{array}{c}\text { BCR } 482 \text { Trace elements in } \\
\text { lichen }\end{array}$ & 0,03 & 0,09 & 0,2 & 0,7 & $0,85 \pm 0,07$ \\
\hline \multicolumn{6}{|c|}{$t_{i}=8 h ; t_{d}=3 d$} \\
\hline $\begin{array}{l}\text { IAEA- } 336 \text { Trace and minor } \\
\text { elements in lichen }\end{array}$ & 0,016 & 0,049 & 0,12 & 0,37 & $0,63(0,55-0,71)$ \\
\hline $\begin{array}{c}\text { BCR } 482 \text { Trace elements in } \\
\text { lichen }\end{array}$ & 0,015 & 0,047 & 0,11 & 0,33 & $0,85 \pm 0,07$ \\
\hline
\end{tabular}

Fonte: autora da dissertação.

Para a determinação de As nos outros MRCs e nas amostras de biomonitores da poluição atmosférica, optou-se pelo tempo de irradiação de $1 \mathrm{~h}$, pela medição do pico de energia de raios gama de 559,10 keV e tempo de decaimento de 1 dia, tendo em vista que os resultados obtidos para os dois tempos de decaimento nesses MRCs apresentaram boa precisão e exatidão (baixos valores de desvio padrão relativo, HORRAT <2, erro relativo e $\mid Z$ score $\mid<$ 2). 
6.2.2 Resultados de arsênio obtidos nos materiais de referência certificados

Além dos dois MRCs analisados para o estabelecimento de condições de irradiação para a determinação de As pela NAA, outros três MRCs foram irradiados por $1 \mathrm{~h}$, com a finalidade de se avaliar a qualidade analítica dos resultados da determinação desse elemento. As frações mássicas médias com seus respectivos desvios padrão, desvios padrão relativos, erros relativos, valores de HORRAT e de $Z$ score obtidos nessas análises estão apresentados na Tabela 12, juntamente aos valores dos certificados para comparação. Os resultados individuais das determinações de As nos MRCs estão apresentados na Tabela A.1, no Apêndice A.

Tabela 12 - Média das frações mássicas de arsênio, em $\mu \mathrm{g} \mathrm{g}^{-1}$, obtidas por meio de irradiações de $1 \mathrm{~h}$ e pela medida do pico de energia de raios gama de 559,10 $\mathrm{keV}$ nos materiais de referência certificados.

\begin{tabular}{ccccccc}
\hline $\begin{array}{c}\text { Material de } \\
\text { referência certificado }\end{array}$ & $\mathrm{M} \pm \mathrm{DP}(\mathrm{n})$ & $\mathrm{DPR}, \%$ & HORRAT & $\begin{array}{c}\mathrm{ER}, \\
\%\end{array}$ & $\begin{array}{c}\mathrm{Z} \\
\text { score }\end{array}$ & $\begin{array}{c}\text { Valor do } \\
\text { certificado }\end{array}$ \\
\hline $\begin{array}{c}\text { INCT M-4* } \\
\text { Cormorant tissue }\end{array}$ & $0,1150 \pm 0,0039(4)$ & 3,4 & 0,15 & 4,9 & $-0,8$ & $0,121 \pm 0,012$ \\
\hline $\begin{array}{c}\text { IAEA-085 } \\
\text { Human hair }\end{array}$ & $0,1224 \pm 0,0096(4)$ & 11,1 & 0,35 & $-^{* *}$ & - & ${ }^{* * *}$ \\
\hline $\begin{array}{c}\text { NCR DOLT-3* } \\
\text { Dogfish liver }\end{array}$ & $9,75 \pm 0,34(4)$ & 3,5 & 0,30 & 4,4 & $-1,1$ & $10,2 \pm 0,5$ \\
\hline * Determinação realizada após 4 d de & & & & & & \\
\hline
\end{tabular}

* Determinação realizada após 4 d de decaimento; ${ }^{* *}$ - indica não calculado; ${ }^{\star \star \star}$ MRC sem valor certificado para o As;

Fonte: autora da dissertação.

Observa-se, na Tabela 12, que foram obtidos resultados satisfatórios quanto a precisão e exatidão, com valores de HORRAT $<2$ e com $\mid Z$ score $\mid<2$, indicando a viabilidade a aplicação do método de NAA para a determinação de As em amostras ambientais.

Os MRCs INCT M-4 Cormorant tissue e NCR DOLT-3 Dogfish liver apresentaram alta atividade de ${ }^{24} \mathrm{Na}\left(\mathrm{t}_{1 / 2}=14,96 \mathrm{~h}\right)$ um dia após a irradiação, 
levando a um alto valor da percentagem de tempo morto. Por esse motivo, as determinações de As nesses materiais foram realizadas após 4 dias de decaimento.

Para uma melhor visualização, os valores de HORRAT e de Z score obtidos na determinação de As nos MRCs por meio das irradiações de $1 \mathrm{~h}$ e pela medição do pico de 559,10 keV estão apresentados também na Figura 13.

Figura 13 - Valores de HORRAT (a) e de Z score (b) na determinação de arsênio nos materiais de referência certificados.

(a)

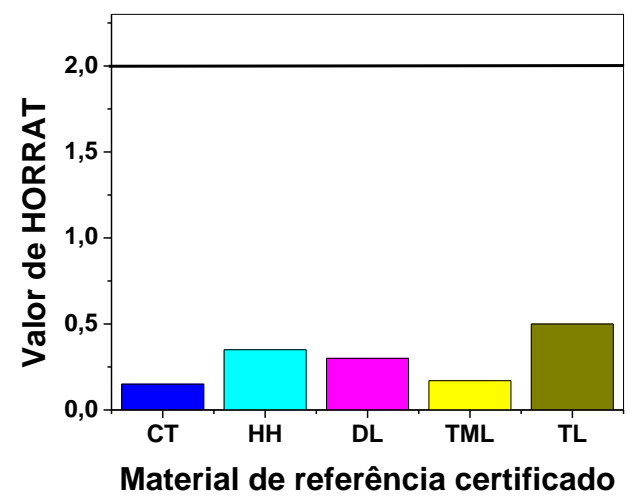

(b)

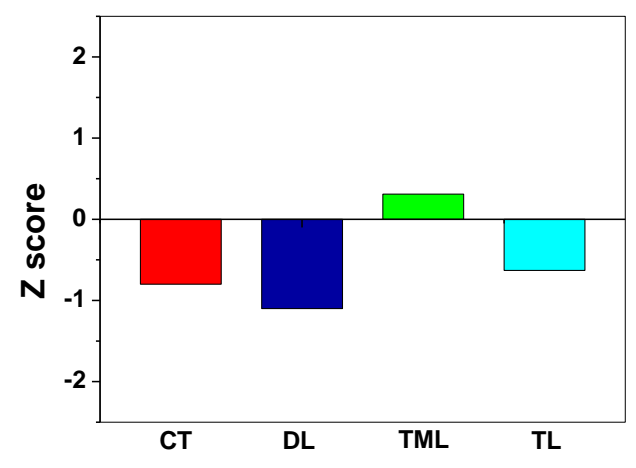

Material de referência certificado

CT: INCT M-4 Cormorant tissue; HH: IAEA-085 Human hair; DL: NCR DOLT-3 Dogfish liver; TML: IAEA-336 Trace and minor elements in lichen; TL: BCR 482 Trace elements in lichen.

Fonte: autora da dissertação.

$\mathrm{Na}$ Tabela 13, são apresentados os limites de detecção (LD) e de quantificação (LQ) para As obtidos na análise dos MRCs juntamente com os respectivos valores do certificado. Nessa Tabela, os LDs e LQs obtidos estão abaixo dos valores de fração mássica de As apresentados nos certificados dos materiais analisados, indicando a viabilidade da aplicação do procedimento utilizado para análise desse tipo de material. 
Tabela 13 - Limites de detecção (LD) e de quantificação (LQ) de arsênio, em $\mu \mathrm{g}$

$\mathrm{g}^{-1}$, obtidos pela medida do pico de energia de raios gama de 559,10 keV nos materiais de referência certificados irradiados por $1 \mathrm{~h}$.

\begin{tabular}{cccc}
\hline $\begin{array}{c}\text { Materiais de referência } \\
\text { certificados }\end{array}$ & LD & LQ & $\begin{array}{c}\text { Valor do } \\
\text { certificado, } \mu \mathrm{g} \mathrm{g}^{-1}\end{array}$ \\
\hline INCT M-4 Cormorant tissue & 0,03 & 0,09 & $0,121 \pm 0,012$ \\
IAEA-085 Human hair & 0,01 & 0,03 & $*$ \\
NRC DOLT-3 Dogfish liver & 0,3 & 0,9 & $10,2 \pm 0,5$ \\
\hline
\end{tabular}

${ }^{*}$ MRC sem valor certificado para As.

Fonte: autora da dissertação.

O As não foi detectado no MRC INCT-TL-1 Tea leaves devido ao seu baixo teor nesse material. Dentre os MRCs selecionados (Tabela 1), esse foi o único de origem vegetal em que esse elemento não foi determinado.

\subsubsection{Resultados de arsênio em amostras de biomonitores}

6.2.3.1 Resultados de arsênio obtidos nas cascas de árvore

Os resultados de fração mássica média, desvio padrão relativo (DPR), valor de HORRAT, LD e LQ obtidos na análise das amostras de casca de árvore estão apresentados na Tabela 14. Observa-se, nessa Tabela, que os DPRs variaram entre 1,9 e $28,4 \%$ e os valores de HORRAT foram inferiores a 2, o que é considerado satisfatório em relação à precisão, de acordo com Wood (1999). Na Figura 14 são apresentados os valores de HORRAT para melhor visualização. Além disso, os LDs e LQs de As encontrados nessa Tabela são inferiores às frações mássicas desse elemento obtidas, demonstrando a viabilidade da aplicação do procedimento de NAA na determinação de As em amostras de casca de árvore. 
Tabela 14 - Frações mássicas médias, limites de detecção (LDs) e de quantificação (LQs) de arsênio obtidos nas análises das cascas de árvore.

Resultados em $\mu \mathrm{g} \mathrm{g}{ }^{-1}$.

\begin{tabular}{cccccc}
\hline $\begin{array}{c}\text { Código da } \\
\text { amostra }\end{array}$ & $\mathrm{M} \pm \mathrm{DP}(\mathrm{n})$ & $\mathrm{DPR}, \%$ & HORRAT & LD & LQ \\
\hline C1 & $0,293 \pm 0,043(4)$ & 14,8 & 0,77 & 0,03 & 0,10 \\
C2 & $0,322 \pm 0,020(4)$ & 6,4 & 0,33 & 0,02 & 0,07 \\
C3 & $0,218 \pm 0,013(4)$ & 6,0 & 0,29 & 0,03 & 0,10 \\
C4 & $0,262 \pm 0,038(4)$ & 14,6 & 1,1 & 0,027 & 0,083 \\
C5 & $0,280 \pm 0,043(4)$ & 15,5 & 0,80 & 0,02 & 0,06 \\
C6 & $0,245 \pm 0,036(4)$ & 14,8 & 0,75 & 0,02 & 0,06 \\
C7 & $0,455 \pm 0,037(4)$ & 8,1 & 0,45 & 0,04 & 0,12 \\
C8 & $0,472 \pm 0,031(4)$ & 6,5 & 0,36 & 0,035 & 0,106 \\
C9 & $0,225 \pm 0,019(4)$ & 8,5 & 0,43 & 0,017 & 0,053 \\
C10 & $0,132 \pm 0,037(4)$ & 28,4 & 1,3 & 0,018 & 0,054 \\
C11 & $0,260 \pm 0,033(4)$ & 12,5 & 0,63 & 0,03 & 0,09 \\
C12 & $0,3101 \pm 0,0060(4)$ & 1,9 & 0,10 & 0,04 & 0,11
\end{tabular}

M \pm DP: Média aritmética e desvio padrão; $n$ : número de determinações; DPR: desvio padrão relativo.

Fonte: autora da dissertação.

Figura 14 - Valores de HORRAT obtidos na determinação de arsênio nas amostras de casca de árvore.

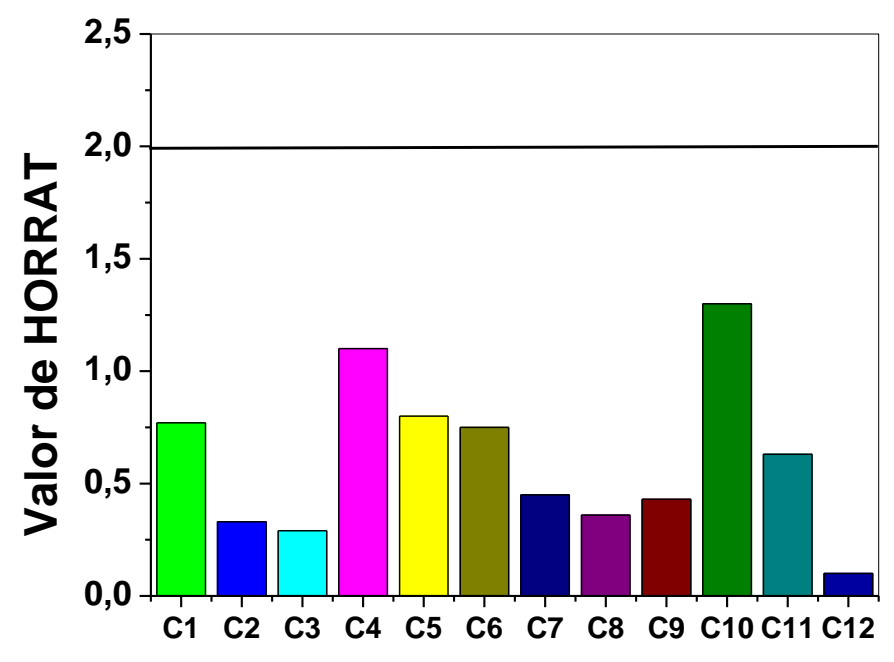

Código da amostra

Fonte: autora da dissertação. 
Os resultados individuais das determinações de As nas cascas de árvore estão apresentados na Tabela A.2 do Apêndice A.

6.2.3.2 Resultados de arsênio obtidos na amostra de líquen

$\mathrm{Na}$ Tabela 15 estão apresentados os resultados de fração mássica média, desvio padrão relativo, valor de HORRAT, LD e LQ da determinação de As na amostra de líquen Canoparmelia texana. O valor de HORRAT obtido nessa análise foi inferior a 2 e os LD e LQ obtidos foram inferiores à fração mássica média. Esses resultados indicam a viabilidade de se aplicar o procedimento de NAA conforme as condições estabelecidas (irradiação de $1 \mathrm{~h}$ e tempo de decaimento de $1 \mathrm{~d}$ ) na determinação de As em amostras de líquen para um futuro projeto de biomonitoramento.

Os resultados individuais dessa determinação de As na amostra de líquen estão na Tabela A.3, no Apêndice A.

Tabela 15 - Fração mássica média, limites de detecção (LD) e de quantificação (LQ) de arsênio obtidos para amostra de líquen, em $\mu \mathrm{g} \mathrm{g}^{-1}$.

\begin{tabular}{cccccc}
\hline $\begin{array}{c}\text { Código da } \\
\text { amostra }\end{array}$ & $\mathrm{M} \pm \mathrm{DP}(\mathrm{n})$ & $\mathrm{DPR}, \%$ & HORRAT & LD & LQ \\
\hline $\mathrm{L} 1$ & $0,345 \pm 0,035(4)$ & 10,0 & 0,53 & 0,018 & 0,054 \\
\hline
\end{tabular}

M \pm DP: Média aritmética e desvio padrão; n: número de determinações; DPR: desvio padrão relativo.

Fonte: autora da dissertação.

6.2.3.3 Resultados de arsênio obtidos em bromélias

Os resultados (frações mássicas médias, DPRs, valores de HORRAT, LDs e LQs) de As obtidos nas amostras de bromélias estão apresentados na Tabela 16. Como pode ser observado nessa Tabela, os teores de As nas 
bromélias são muito baixos (inferiores a $1 \mu \mathrm{g} \mathrm{g}^{-1}$ ) e, consequentemente, a precisão dos resultados é muito baixa, com desvios padrão relativos variando de 17,4 a 37,5\%. Entretanto, os valores de HORRAT calculados (Figura 15) para cada amostra foram satisfatórios, segundo o critério de Wood (1999), ou seja, inferiores a 2. Isso porque esse critério leva em consideração apenas o nível de fração mássica do analito na amostra.

Não foi possível quantificar o As na amostra B3. As altas atividades de ${ }^{24} \mathrm{Na}\left(\mathrm{t}_{1 / 2}=14,96 \mathrm{~h}\right)$ e de ${ }^{42} \mathrm{~K}\left(\mathrm{t}_{1 / 2}=12,36 \mathrm{~h}\right)$ mascararam as atividades do pico de $559,10 \mathrm{keV}$ do ${ }^{76}$ As. Dessa maneira, foram calculados os limites de detecção e de quantificação de As nessa amostra de bromélia.

Os resultados individuais das determinações de As nas bromélias estão apresentados na Tabela A.4, no Apêndice A.

Tabela 16 - Frações mássicas médias, limites de detecção (LDs) e de quantificação (LQs) de arsênio obtidos nas amostras de bromélias em $\mu \mathrm{g} \mathrm{g}^{-1}$.

\begin{tabular}{cccccc}
\hline $\begin{array}{c}\text { Código da } \\
\text { amostra }\end{array}$ & $\mathrm{M} \pm \mathrm{DP}(\mathrm{n})$ & DPR, \% & HORRAT & LD & LQ \\
\hline B1 & $0,165 \pm 0,062(4)$ & 37,5 & 1,8 & 0,03 & 0,10 \\
B2 & $0,187 \pm 0,066(4)$ & 35,4 & 1,7 & 0,02 & 0,06 \\
B3 & $-^{*}$ & - & - & 0,34 & 1,02 \\
B4 & $0,270 \pm 0,047(4)$ & 17,4 & 0,89 & 0,018 & 0,055 \\
\hline
\end{tabular}

M \pm DP: Média aritmética e desvio padrão; n: número de determinações; DPR: desvio padrão relativo. -: indica que não foi determinado devido ao problema de interferência do ${ }^{24} \mathrm{Na}$ e do ${ }^{42} \mathrm{~K}$.

Fonte: autora da dissertação. 
Figura 15 - Valores de HORRAT na determinação de arsênio nas amostras de bromélias analisadas.

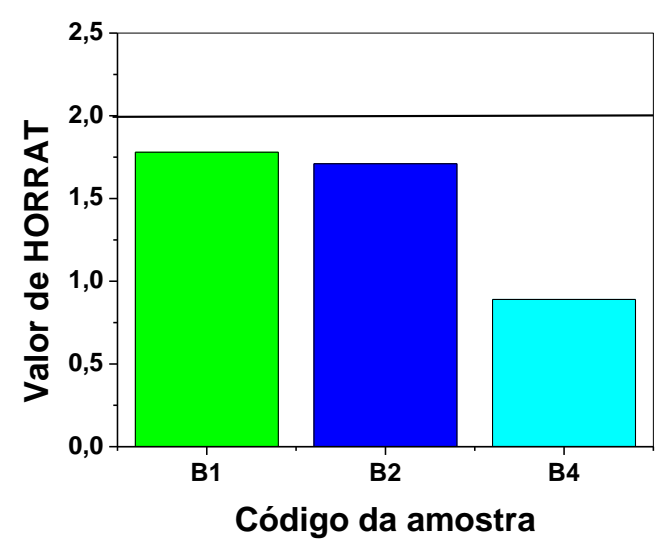

Fonte: autora da dissertação.

\subsection{Resultados da determinação de cobre}

6.3.1 Resultados de cobre obtidos nos materiais de referência certificados

O Cu foi determinado nos MRCs por meio de irradiações de 20 s e por meio de irradiações de $1 \mathrm{~h}$.

6.3.1.1 Resultados do cobre nos materiais de referência certificados por meio de irradiações de curta duração

$\mathrm{Na}$ Tabela 17 estão os resultados das determinações de Cu nos MRCs obtidas por meio de irradiações de curta duração de $20 \mathrm{~s}$, em que o radioisótopo ${ }^{66} \mathrm{Cu}\left(\mathrm{t}_{1 / 2}=5,10 \mathrm{~min}\right)$ foi medido. Nessa Tabela, são apresentados valores médios de fração mássica com seus respectivos desvios padrão, desvios padrão relativos, valores de HORRAT, erros relativos, $Z$ score e os valores dos certificados para comparação. 
Para melhor visualização, os valores de HORRAT e de Z score obtidos na análise dos materiais de referência certificados estão apresentados na Figura 16.

Tabela 17 - Frações mássicas médias de cobre, em $\mu \mathrm{g} \mathrm{g}^{-1}$, obtidas nos materiais de referência certificados por meio de irradiações de curta duração.

\begin{tabular}{ccccccc}
\hline $\begin{array}{c}\text { Material de referência } \\
\text { certificado }\end{array}$ & $\mathrm{M} \pm \mathrm{DP}(\mathrm{n})$ & $\begin{array}{c}\text { DPR, } \\
\%\end{array}$ & $\begin{array}{c}\text { HORRAT } \\
\%\end{array}$ & $\begin{array}{c}\mathrm{ER}, \\
\%\end{array}$ & Z score & $\begin{array}{c}\text { Valor do } \\
\text { certificado }\end{array}$ \\
\hline INCT-M4 Cormorant tissue $^{*}$ & $18,8 \pm 1,2(4)$ & 6,2 & 0,60 & 3,5 & $-0,5$ & $19,5 \pm 1,2$ \\
IAEA-085 Human hair & $16,9 \pm 1,5(4)$ & 8,6 & 0,83 & 0,69 & 0,064 & $16,8 \pm 1,0 *$ \\
NCR DOLT-3 Dogfish liver & $31,5 \pm 5,2(4)$ & 16,5 & 1,74 & 1,1 & 0,064 & $31,2 \pm 1,0$ \\
NIST 1577b Bovine liver & $170 \pm 7,0(4)$ & 4,1 & 0,55 & 6,2 & 1,2 & $160 \pm 8$ \\
NIST 1566b Oyster tissue & $73,0 \pm 4,8(4)$ & 6,6 & 0,78 & 1,9 & 0,29 & $71,6 \pm 1,6$ \\
BCR 186 Pig kidney & $30,4 \pm 1,5(4)$ & 4,8 & 0,50 & 4,6 & $-0,99$ & $31,9 \pm 0,4$ \\
\hline
\end{tabular}

*Irradiado por $30 \mathrm{~s}$; ** Valor informativo; M \pm DP (n): Média aritmética e desvio padrão; n: número de determinações; DPR: desvio padrão relativo; ER: erro relativo percentual.

Fonte: autora da dissertação. 
Figura 16 - Valores de HORRAT (a) e de Z score (b) obtidos na determinação de cobre nos materiais de referência certificados.

(a)

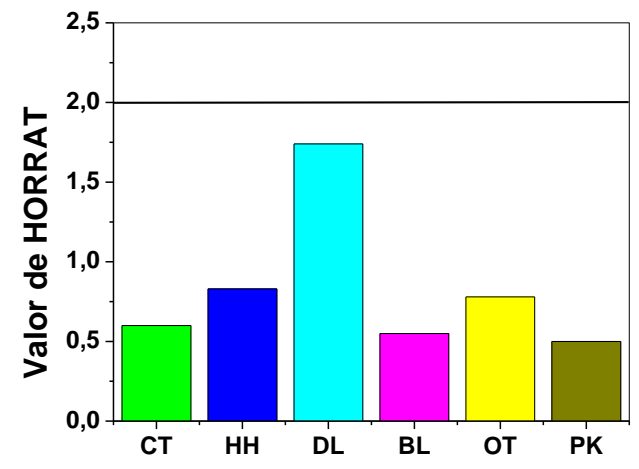

Material de referência certificados (b)

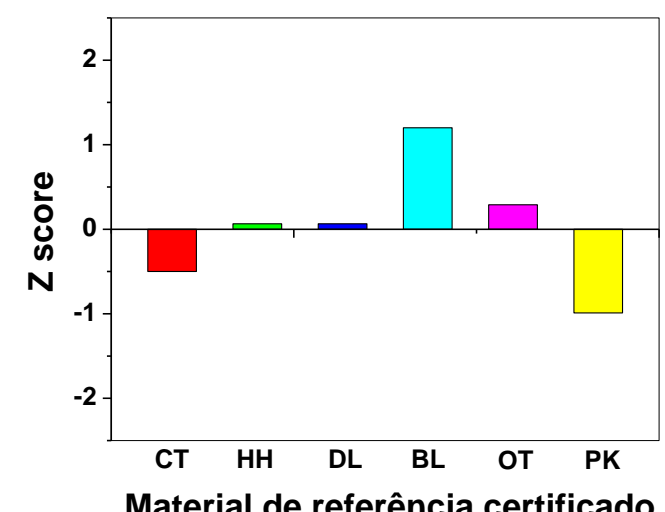

CT: INCT M-4 Cormorant tissue; HH: IAEA-085 Human hair; DL: NCR DOLT-3 Dogfish liver; BL: NIST 1577b Bovine liver; OT: NIST 1566b Oyster tissue; PK: BCR 186 Pig kidney.

Fonte: autora da dissertação.

Os resultados da Tabela 17 e da Figura 16 indicam boa precisão e exatidão para os materiais analisados, uma vez que foram obtidos valores de HORRAT menores que 2, baixas percentagens de erro relativo e valores aceitáveis de $Z$ score $(\mid Z$ score $\mid<2)$.

Os resultados individuais dessas determinações estão apresentados na Tabela B.1 do Apêndice B.

Na Tabela 18, os resultados de LD e LQ obtidos para os MRCs estão apresentados. Os LDs e LQs obtidos são inferiores aos valores de fração mássica de $\mathrm{Cu}$ presente nesses materiais, o que indica a aplicabilidade do procedimento de NAA para a determinação desse elemento nesse tipo de matriz. 
Tabela 18 - Valores de limite de detecção (LD) e de quantificação (LQ) obtidos nas determinações de cobre nos materiais de referência certificados por meio das irradiações de curta duração.

\begin{tabular}{cccc}
\hline Material de referência certificado & LD & LQ & $\begin{array}{c}\text { Valor do } \\
\text { certificado }\end{array}$ \\
\hline INCT-M4 Cormorant tissue* & 3 & 9 & $19,5 \pm 1,2$ \\
IAEA-085 Human hair & 2,1 & 6,4 & $16,8 \pm 1,0^{* *}$ \\
NCR DOLT-3 Dogfish liver & 5,9 & 18 & $31,2 \pm 1,0$ \\
NIST 1577b Bovine liver & 4,2 & 12,8 & $160 \pm 8$ \\
NIST 1566b Oyster tissue & 6 & 18 & $71,6 \pm 1,6$ \\
BCR 186 Pig kidney & 6 & 18 & $31,9 \pm 0,4$ \\
\hline
\end{tabular}

*Irradiado por $30 \mathrm{~s}$; ** Valor informativo.

Fonte: autora da dissertação.

6.3.1.2 Resultados de cobre obtidos nos materiais de referência certificados por meio de irradiações de longa duração

Não foi possível determinar $\mathrm{Cu}$ por meio de irradiações de $1 \mathrm{~h}$ nos mesmos MRCs em que se determinou esse elemento por meio de irradiações de curta duração, uma vez que a alta atividade do ${ }^{24} \mathrm{Na}\left(\mathrm{t}_{1 / 2}=14,96 \mathrm{~h}\right)$ mascarou a atividade do ${ }^{64} \mathrm{Cu}\left(\mathrm{t}_{1 / 2}=12,70 \mathrm{~h}\right)$. Por meio da irradiação de $1 \mathrm{~h}$, foi possível determinar o $\mathrm{Cu}$ apenas nos MRCs IAEA-085 Human hair e INCT-TL-1 Tea leaves.

Os resultados dessas determinações (frações mássicas médias, desvios padrão, DPRs, HORRAT, ERs, Z score) encontram-se na Tabela 19, juntamente aos LDs e LQs obtidos e aos valores dos certificados para comparação. No caso dessas determinações, foram realizadas medições das atividades com tempos de decaimento de 1 e 2 dias.

Os resultados individuais do $\mathrm{Cu}$ nesses materiais irradiados por $1 \mathrm{~h}$ estão na Tabela B.2 do Apêndice B. 
Tabela 19 - Resultados de cobre, em $\mu \mathrm{g} \mathrm{g}{ }^{-1}$, obtidas por meio de irradiações de 1 $\mathrm{h}$ nos materiais de referência certificados.

\begin{tabular}{|c|c|c|c|c|c|c|}
\hline \multirow[b]{2}{*}{ MRC } & \multirow{2}{*}{$\begin{array}{l}\text { Parâmetros } \\
\text { avaliados }\end{array}$} & \multicolumn{2}{|c|}{ Resultados do presente trabalho } & \multirow[b]{2}{*}{ LD } & \multirow[b]{2}{*}{ LQ } & \multirow{2}{*}{$\begin{array}{l}\text { Valor do } \\
\text { certificado }\end{array}$} \\
\hline & & $\operatorname{td}_{1}{ }^{*}$ & $\mathrm{td}_{2}$ & & & \\
\hline IAEA-085 & $M \pm D P(n)$ & $17,9 \pm 2,3(4)$ & $16,4 \pm 2,6(4)$ & 3,1 & 9,3 & $16,8 \pm 1,0^{\star \star}$ \\
\hline \multirow[t]{4}{*}{ Human Hair } & DPR, \% & 13,0 & 16,4 & & & \\
\hline & HORRAT & 1,2 & 0,83 & & & \\
\hline & $\mathrm{ER}, \%$ & 6,7 & 2,4 & & & \\
\hline & Z score & $-0,36$ & 0,12 & & & \\
\hline INCT-TL1 & $M \pm D P(n)$ & $21,9 \pm 2,7(3)$ & $21,4 \pm 4,0(3)$ & 6 & 17 & $20,4 \pm 1,5$ \\
\hline \multirow[t]{4}{*}{ Tea Leaves } & DPR, \% & 17,6 & 15,3 & & & \\
\hline & HORRAT & 1,7 & 1,5 & & & \\
\hline & $E R, \%$ & 7,4 & 4,7 & & & \\
\hline & Z score & 0,54 & 0,23 & & & \\
\hline
\end{tabular}

${ }^{*} \operatorname{td}_{1}=1$ dia; $\operatorname{td}_{2}=2$ dias; ${ }^{* *}$ Valor informativo; $M \pm D P(n):$ Média aritmética $e$ desvio padrão de $n$ determinações; DPR: desvio padrão relativo; ER: erro relativo percentual.

Fonte: autora da dissertação.

Os resultados da Tabela 19 indicam valores de HORRAT $<2$, percentagens de erros relativos inferiores a $7,4 \%$ e valores satisfatórios de $Z$ score $(\mid Z$ score $\mid<2)$, demonstrando boa precisão e exatidão dos dados obtidos.

Para a determinação do $\mathrm{Cu}$ nas amostras de biomonitores por meio das irradiações de $1 \mathrm{~h}$, resolveu-se utilizar o tempo de decaimento de 1 dia para as contagens, uma vez que ambos os tempos de decaimento (1 e 2 d) apresentaram resultados adequados no que se refere à exatidão e precisão. Além disso, escolhendo o tempo de decaimento de $1 \mathrm{~d}$, foi possível realizar a determinação simultânea do Cu e do As numa mesma irradiação e contagem.

Dentre os MRCs selecionados de origem vegetal, o $\mathrm{Cu}$ não foi detectado nos materiais IAEA-336 Trace and minor elements in lichen e BCR 482 Trace elements in lichen. Os limites de detecção obtidos para esses dois MRCs, tanto nas irradiações de $1 \mathrm{~h}$, quanto nas de $20 \mathrm{~s}$, foram superiores aos valores de frações mássicas desse elemento apresentados nos seus certificados. 
6.3.2 Resultados de cobre obtidos em amostras de biomonitores

6.3.2.1 Resultados de cobre obtidos nas cascas de árvore

$\mathrm{Na}$ Tabela 20 estão as frações mássicas de Cu obtidas nas cascas de árvore por meio de irradiações de $20 \mathrm{~s}$ e $1 \mathrm{~h}$, bem como os respectivos limites de detecção e de quantificação.

Observa-se, nessa Tabela, que os LDs obtidos por meio de irradiação de $1 \mathrm{~h}$ das amostras são menores do que os obtidos nas irradiações de $20 \mathrm{~s}$. No caso das irradiações de curta duração, o $\mathrm{Cu}$ não foi detectado em todas as irradiações realizadas, uma vez que os LDs obtidos nessas irradiações estão próximos às frações mássicas desse elemento nas amostras. Além disso, nessas medidas, altos valores de incerteza associados às taxas de contagens do pico do ${ }^{66} \mathrm{Cu}$ foram obtidos.

Todos os valores de HORRAT foram considerados satisfatórios segundo o critério de Wood (1999) para os resultados das irradiações de $1 \mathrm{~h}$, demonstrando a precisão dos resultados obtidos. Já nas irradiações de $20 \mathrm{~s}$, foram obtidos dois valores de HORRAT maiores do que 2, como mostrado na Tabela 20 e na Figura 17.

Com exceção da amostra C12, todos os LDs e LQs obtidos nas irradiações de $1 \mathrm{~h}$ foram inferiores às respectivas frações mássicas, indicando a viabilidade da aplicação do procedimento de NAA para a determinação de Cu em amostras de casca de árvore.

Os resultados individuais dessas determinações de $\mathrm{Cu}$ nas cascas de árvore estão apresentados nas Tabela B.3 e B.4 do Apêndice 3. 
Tabela 20 - Frações mássicas médias, limites de detecção (LD) e de quantificação (LQ) de cobre obtidos por meio de irradiações de $1 \mathrm{~h}$ e de $20 \mathrm{~s}$ nas amostras de casca de árvore, em $\mu \mathrm{g} \mathrm{g} \mathrm{g}^{-1}$.

\begin{tabular}{|c|c|c|c|c|c|c|c|c|c|c|}
\hline \multirow{2}{*}{$\begin{array}{l}\text { Código da } \\
\text { amostra }\end{array}$} & \multicolumn{5}{|c|}{$t_{i}=1 \mathrm{~h}$} & \multicolumn{5}{|c|}{$t_{i}=20 \mathrm{~s}$} \\
\hline & $M \pm D P(n)$ & $\begin{array}{c}\text { DPR, } \\
\%\end{array}$ & HORRAT & LD & $\mathrm{LQ}$ & $M \pm D P(n)$ & $\begin{array}{c}\text { DPR, } \\
\%\end{array}$ & HORRAT & LD & $\mathrm{LQ}$ \\
\hline $\mathrm{C} 1$ & $42,7 \pm 4,5(4)$ & 10,6 & 1,4 & 6 & 19 & $30,4 \pm 5,4(4)$ & 18,0 & 1,9 & 16 & 47 \\
\hline $\mathrm{C} 2$ & $61,7 \pm 6,3(4)$ & 10,2 & 1,2 & 6 & 19 & $49,0 \pm 4,7(4)$ & 9,6 & 0,66 & 21 & 64 \\
\hline C3 & $57,3 \pm 2,4(4)$ & 4,2 & 0,48 & 6 & 19 & $57,9 \pm 8,3(4)$ & 14,3 & 1,6 & 14 & 42 \\
\hline C4 & $273 \pm 20(4)$ & 7,4 & 1,1 & 8 & 24 & $237 \pm 17(4)$ & 7,3 & 1,0 & 20 & 61 \\
\hline C5 & $23,1 \pm 4,6(4)$ & 19,9 & 1,9 & 5 & 15 & $N D^{*}$ & - & - & 27 & 81 \\
\hline C6 & $27,4 \pm 2,4(4)$ & 8,6 & 0,88 & 4 & 13 & $40,5 \pm 9,2(1)^{\star *}$ & - & - & 16 & 49 \\
\hline $\mathrm{C7}$ & $26,96 \pm 0,75$ & 2,8 & 0,28 & 6 & 18 & $29 \pm 14(1)^{\star \star}$ & - & - & 27 & 82 \\
\hline C8 & $38,7 \pm 6,2(4)$ & 16,1 & 1,7 & 5 & 16 & $40 \pm 11(2)$ & 27,9 & 3,0 & 28 & 84 \\
\hline C9 & $18,8 \pm 2,0(4)$ & 10,4 & 1,0 & 4 & 11 & ND & - & - & 16 & 47 \\
\hline C10 & $27,6 \pm 3,1(4)$ & 11,1 & 1,1 & 5 & 15 & $23,45 \pm 0,81(2)$ & 3,5 & 0,3 & 20 & 61 \\
\hline C11 & $27,5 \pm 1,9(4)$ & 6,9 & 0,7 & 6 & 17 & ND & - & - & 21 & 64 \\
\hline $\mathrm{C} 12$ & $26,7 \pm 3,9(4)$ & 14,5 & 1,5 & 12 & 36 & $25,1 \pm 6,7(2)$ & 26,6 & 2,7 & 11 & 32 \\
\hline
\end{tabular}

*ND: não detectado; - não determinado; M \pm DP: Média aritmética e desvio padrão; n: número de determinações; DPR: desvio padrão relativo; ** resultado de uma determinação com valor de incerteza associado às taxas de contagens.

Fonte: autora da dissertação. 
Figura 17 - Valores de HORRAT obtidos na determinação de cobre nas amostras de casca de árvore.

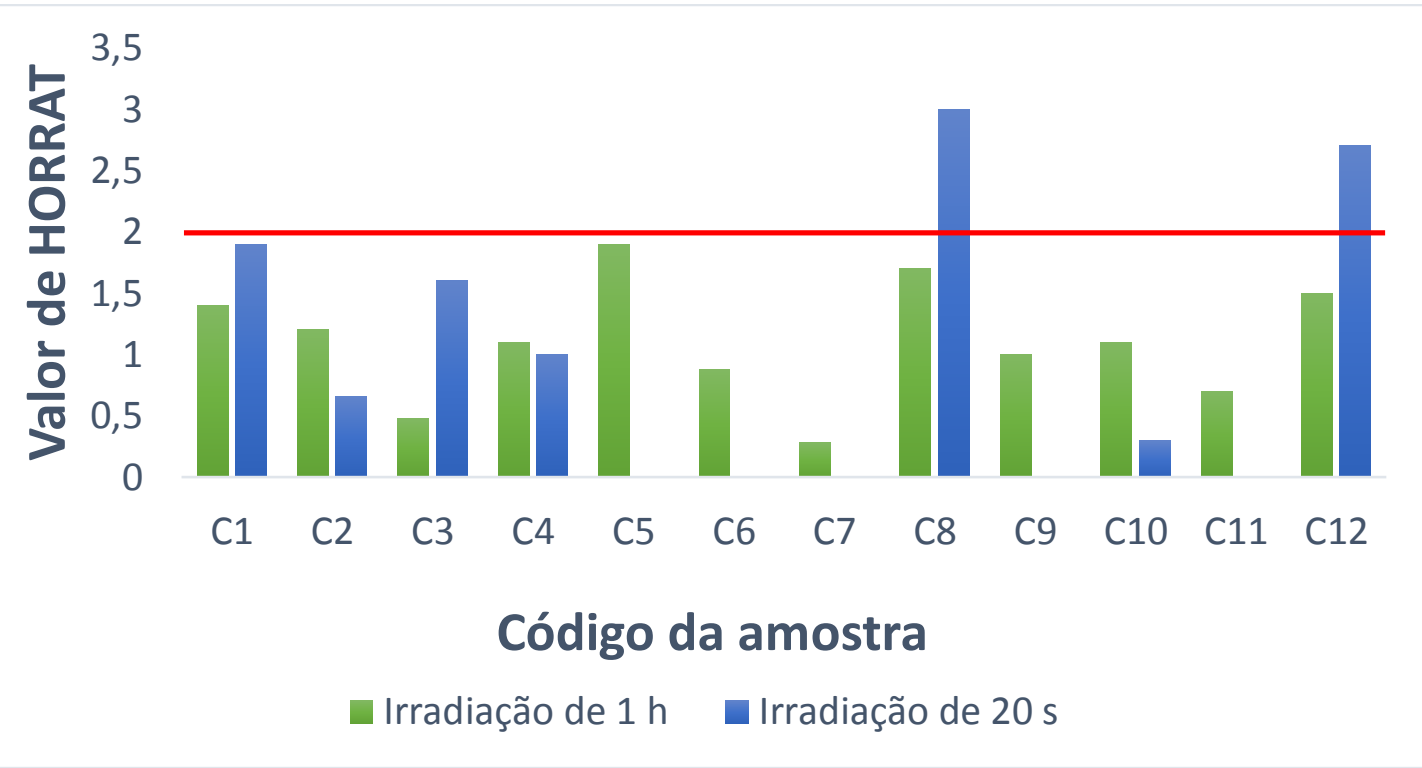

Fonte: autora da dissertação.

6.3.2.2 Resultados de cobre na amostra de líquen

Não foi possível determinar esse elemento na amostra de líquen por meio de irradiações de $20 \mathrm{~s}$, pois a fração mássica presente na amostra estava abaixo do limite de detecção (27 $\left.\mu \mathrm{g} \mathrm{g}^{-1}\right)$ obtido para esse tempo de irradiação. $\mathrm{Na}$ Tabela 21, encontram-se os resultados (fração mássica média, DPR, valor de HORRAT, LD e LQ) das determinações de Cu na amostra de líquen obtidos por meio de irradiações de $1 \mathrm{~h}$.

Observa-se, nessa Tabela, que os resultados são satisfatórios quanto à sua precisão, de acordo com o critério de Wood (1999) (valor de HORRAT < 2). Além disso, os valores de LD e LQ obtidos são inferiores ao valor de fração média, indicando a aplicabilidade do procedimento proposto para determinação de $\mathrm{Cu}$ em amostras de líquen para futuros trabalhos de biomonitoramento.

Os resultados individuais da determinação de Cu na amostra de líquen estão na Tabela B.5 do Apêndice B. 
Tabela 21 - Fração mássica média, limites de detecção (LD) e de quantificação

(LQ) de cobre obtidos na análise de líquen por meio de irradiações de $1 \mathrm{~h}$.

Resultados em $\mu \mathrm{g} \mathrm{g}^{-1}$.

\begin{tabular}{cccccc}
\hline $\begin{array}{c}\text { Código da } \\
\text { amostra }\end{array}$ & $\mathrm{M} \pm \mathrm{DP}(\mathrm{n})$ & $\mathrm{DPR}, \%$ & HORRAT & $\mathrm{LD}$ & $\mathrm{LQ}$ \\
\hline $\mathrm{L} 1$ & $13,6 \pm 2,7(4)$ & 19,5 & 1,8 & 4 & 12 \\
\hline
\end{tabular}

M \pm DP: Média aritmética e desvio padrão; n: número de determinações; DPR: desvio padrão relativo.

Fonte: autora da dissertação.

\subsubsection{Resultados de cobre em bromélias}

Os resultados obtidos na determinação de Cu por meio das irradiações de $1 \mathrm{~h}$ nas amostras de bromélia estão na Tabela 22. Não foi possível determinar esse elemento nas amostras B3 e B4. A amostra B3 apresentou altas atividades de ${ }^{24} \mathrm{Na}\left(\mathrm{t}_{1 / 2}=14,96 \mathrm{~h}\right)$ e de ${ }^{42} \mathrm{~K}\left(\mathrm{t}_{1 / 2}=12,36 \mathrm{~h}\right) \mathrm{e}$, por esse motivo, as medições das atividades gama dessa amostra só puderam ser realizadas 4 d após a irradiação, ou seja, cerca de 8 meias-vidas do ${ }^{64} \mathrm{Cu}$, levando a não detecção desse radionuclídeo. No caso da amostra B4, na medição feita após $1 \mathrm{~d}$ de decaimento, não foi detectado o ${ }^{64} \mathrm{Cu}$ devido à baixa taxa de contagens.

As amostras B1 e B2 apresentaram resultados satisfatórios quanto à precisão, segundo o critério de Wood (1999), uma vez que foram obtidos valores de HORRAT inferiores a 2. Para a amostra B1, o valor de fração mássica média obtido foi superior ao valor de LD, porém ligeiramente inferior ao valor LQ. Para a amostra B2, os valores de LD e LQ foram inferiores à fração mássica média obtida.

Esses resultados de $\mathrm{Cu}$ em bromélias indicam que a possibilidade de detecção desse elemento nessa espécie de biomonitor depende dos seus teores e dos teores de $\mathrm{Na}$ e $\mathrm{K}$ na amostra.

Os resultados individuais da determinação de $\mathrm{Cu}$ nas amostras de bromélias estão na Tabela B.6 do Apêndice B. 
Tabela 22 - Médias das frações mássicas, limites de detecção (LD) e de quantificação (LQ) de cobre, em $\mu \mathrm{g} \mathrm{g}^{-1}$, obtidos nas análises de bromélias. Tempo de irradiação $=1 \mathrm{~h}$.

\begin{tabular}{cccccc}
\hline $\begin{array}{c}\text { Código da } \\
\text { amostra }\end{array}$ & $\mathrm{M} \pm \mathrm{DP}(\mathrm{n})$ & DPR, \% & HORRAT & LD & LQ \\
\hline B1 & $17,4 \pm 2,2(3)$ & 12,5 & 1,20 & 6 & 19 \\
B2 & $16,9 \pm 3,5(4)$ & 20,6 & 1,97 & 5 & 16 \\
B3 & $-{ }^{*}$ & - & - & 200 & 600 \\
B4 & - & - & - & 3 & 10
\end{tabular}

M \pm DP: Média aritmética e desvio padrão; $n$ : número de determinações; DPR: desvio padrão relativo.

* -: indica não detectado.

Fonte: autora da dissertação.

Não foi possível determinar o $\mathrm{Cu}$ por meio de irradiações de curta duração nas amostras de bromélia. Os limites de detecção e quantificação obtidos para esse tempo de irradiação estão apresentados na Tabela 23. Observa-se que, com exceção da amostra B3, os limites obtidos por meio das irradiações de 1 h (pela medida do ${ }^{64} \mathrm{Cu}$ ) são inferiores aos limites obtidos nas irradiações de $20 \mathrm{~s}$ (pela medida do ${ }^{66} \mathrm{Cu}$ ).

Tabela 23 - Valores de limites de detecção (LD) e de quantificação (LQ), em $\mu g$ g${ }^{1}$, obtidos nas análises de bromélias $\left(t_{i}=20 \mathrm{~s}\right)$.

\begin{tabular}{ccc}
\hline $\begin{array}{c}\text { Código da } \\
\text { amostra }\end{array}$ & LD & LQ \\
\hline B1 & 27 & 81 \\
B2 & 27 & 81 \\
B3 & 26 & 79 \\
B4 & 22 & 66 \\
\hline
\end{tabular}

Fonte: autora da dissertação. 


\subsection{Resultados da determinação de mercúrio}

6.4.1 Resultados obtidos no estabelecimento das condições de irradiação para a determinação de mercúrio

Ensaios preliminares foram realizados para a escolha dos tempos de irradiação e do recipiente para irradiação, de modo a evitar a perda de $\mathrm{Hg}$ por volatilização na NAA.

\subsubsection{Avaliação da perda de mercúrio durante a irradiação}

A avaliação da perda de $\mathrm{Hg}$ durante a irradiação foi realizada para os tempos de irradiação de 1 e $8 \mathrm{~h}$ e usando como recipiente para irradiação invólucros e cápsulas de polietileno do tipo W. Nesse caso, a perda foi avaliada determinando $\mathrm{Hg}$ no MRC IAEA-085 Human Hair e considerando que não há perda de $\mathrm{Hg}$ do padrão sintético. Os resultados das frações mássicas nesse MRC obtidos nestes ensaios são apresentados na Tabela 24.

Tabela 24 - Frações mássicas de mercúrio no MRC IAEA-085 Human Hair, $\mu g$ g${ }^{1}$, obtidas para diferentes condições de irradiação.

\begin{tabular}{|c|c|c|c|}
\hline \multicolumn{3}{|c|}{ Condições de irradiação } & \multirow[b]{2}{*}{ Valor do certificado } \\
\hline $\begin{array}{c}1 \text { h de irradiação } \\
\text { em cápsula de } \\
\text { polietileno }\end{array}$ & $\begin{array}{c}1 \mathrm{~h} \text { de irradiação } \\
\text { em invólucro de } \\
\text { polietileno }\end{array}$ & $\begin{array}{c}8 \mathrm{~h} \text { de irradiação } \\
\text { em invólucro de } \\
\text { polietileno }\end{array}$ & \\
\hline $\begin{array}{c}23,23 \pm 0,11 \text { a } 26,75 \\
\pm 0,40\end{array}$ & $\begin{array}{c}23,58 \pm 0,14 \text { a } 25,536 \\
\pm 0,087\end{array}$ & $\begin{array}{c}25,311 \pm 0,020 a \\
25,316 \pm 0,034\end{array}$ & $23,2 \pm 0,8$ \\
\hline
\end{tabular}

Fonte: autora da dissertação.

Conforme mostrado na Tabela 24, os resultados de frações mássicas de $\mathrm{Hg}$ obtidos são concordantes com o valor do certificado, indicando que não houve perda desse $\mathrm{Hg}$ em nenhuma das condições de irradiação utilizadas, 
demonstrando que ambos os recipientes e tempos de irradiação podem ser utilizados para a determinação desse elemento.

Entretanto, após o decaimento do ${ }^{24} \mathrm{Na}\left(\mathrm{t}_{1 / 2}=14,96 \mathrm{~h}\right)$ da amostra, 0 radionuclídeo ${ }^{75} \mathrm{Se}\left(\mathrm{t}_{1 / 2}=119,77 \mathrm{~d}\right)$ foi identificado na alíquota do MRC irradiada por $8 \mathrm{~h}$, como mostrado na Figura 18. Esse fato torna impossível a determinação de $\mathrm{Hg}$ pela medida do ${ }^{203} \mathrm{Hg}$, uma vez que o pico de $279,93 \mathrm{keV}$ do ${ }^{75} \mathrm{Se}$ interfere no pico de $279,20 \mathrm{keV}$ do ${ }^{203} \mathrm{Hg}$.

Figura 18 - Espectro de raios gama na região de 200 a 300 keV da medida do MRC IAEA-085 Human Hair irradiado por 8 h em invólucro de polietileno.

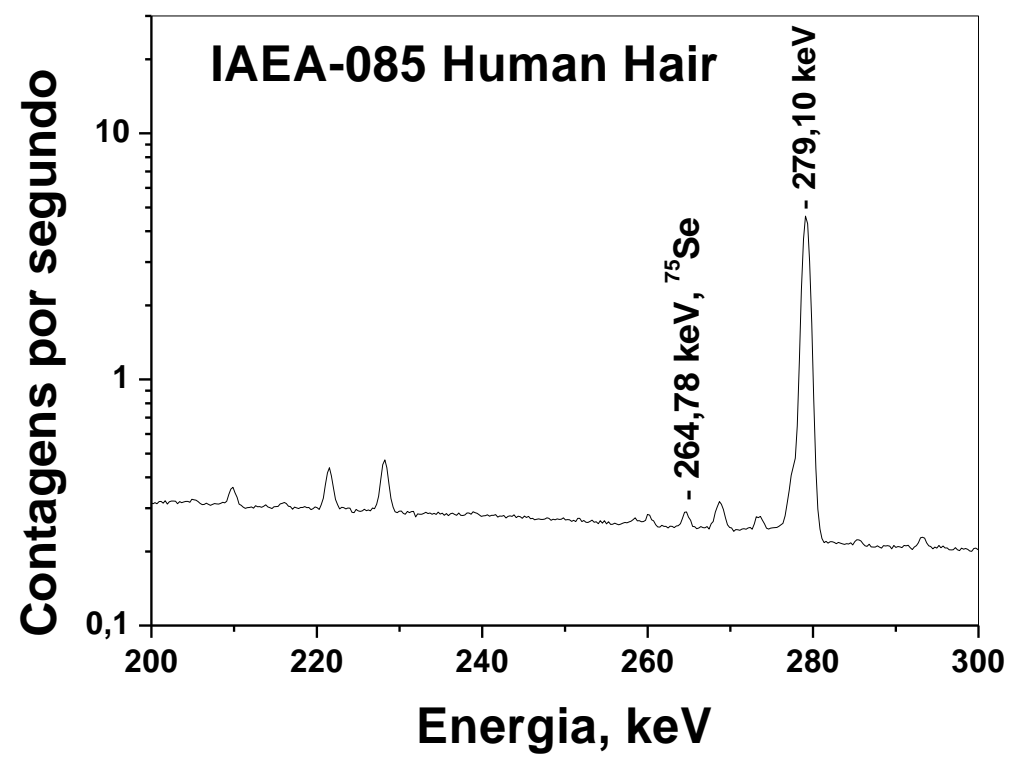

Fonte: autora da dissertação.

Além disso, usando o tempo de irradiação de $8 \mathrm{~h}$, um espectro de raios gama bastante complexo foi obtido na região de baixa energia, como mostrado na Figura 19. De acordo com Zmijewsk (1977), uma importante interferência na determinação de $\mathrm{Hg}$ pela medida do ${ }^{197} \mathrm{Hg}$ é a do ${ }^{198} \mathrm{Au}$, cujos fotopicos de baixa energia interferem na resolução do fotopico do ${ }^{197} \mathrm{Hg}$. O ${ }^{198} \mathrm{Au}$ foi identificado na amostra pelos picos de 68,89 keV e 411,80 keV, que apresentaram picos com altas taxas de contagens. 
Figura 19 - Espectro de raios gama na região de 55 a $90 \mathrm{keV}$ da medida do MRC IAEA-085 Human Hair irradiado por $8 \mathrm{~h}$ em invólucro de polietileno.

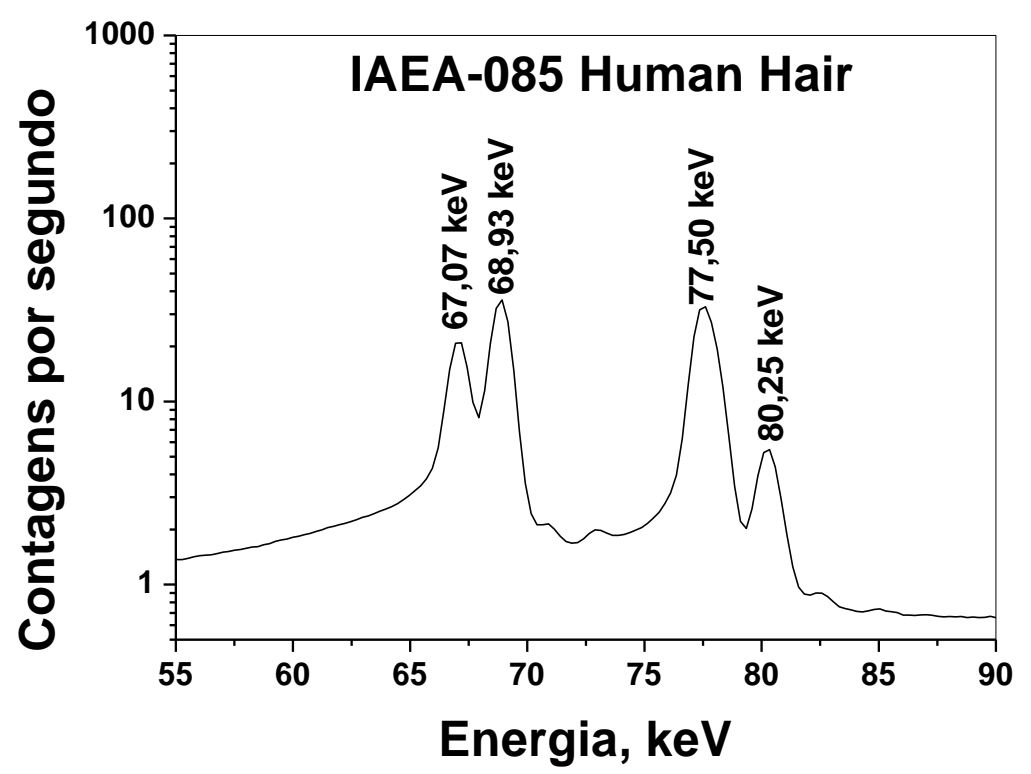

Fonte: autora da dissertação.

Na Figura 19, observa-se os seguintes fotopicos: o de 68,93 keV, um dos fotopicos que indica a presença do ${ }^{198} \mathrm{Au}$ na amostra, o de $77,50 \mathrm{keV}$ do ${ }^{197} \mathrm{Hg}$ e, muito próximo a ele, o de $80,25 \mathrm{keV}$, que é pico de raios $\mathrm{X}$ característico do $\mathrm{Hg}$, formado no decaimento do ${ }^{198} \mathrm{Au}$. Esses dois fotopicos $(77,50 \mathrm{keV}$ e $80,25 \mathrm{keV})$ podem não ser totalmente resolvidos, o que pode ter acarretado em uma interferência espectral no fotopico do ${ }^{197} \mathrm{Hg}$. A ocorrência da interferência do ${ }^{198} \mathrm{Au}$ no fotopico do ${ }^{197} \mathrm{Hg}$ não pôde ser verificada pela determinação da meia-vida, uma vez que esses dois radionuclídeos apresentam meias-vidas muito próximas $\left(64,16 \mathrm{~h}\right.$ para o ${ }^{197} \mathrm{Hg}$ e $64,80 \mathrm{~h}$ para o $\left.{ }^{198} \mathrm{Au}\right)$.

6.4.1.2 Avaliação da perda de mercúrio após a irradiação

A perda de $\mathrm{Hg}$ por volatilização após a irradiação foi verificada pela medida dos padrões sintéticos de $\mathrm{Hg}$ irradiados por $1 \mathrm{~h}$ (em cápsula e em 
invólucro de polietileno) e por $8 \mathrm{~h}$ (em invólucro de polietileno). Para avaliar essa perda, as taxas de contagens obtidas para diferentes tempos de decaimento foram corrigidas, obtendo-se as taxas de decaimento $\left(A_{0}\right)$ para o mesmo tempo de decaimento $\left(t_{0}=0\right)$. Nos dados da Tabela 25 e da Figura 20, as taxas de contagens corrigidas $\left(A_{0}\right)$, para diferentes tempos de decaimento, permaneceram aproximadamente constantes até cerca 14 dias de decaimento, indicando que não houve perda de $\mathrm{Hg}$ até 14 dias após a irradiação, com o padrão desse elemento mantido na sala de contagem a uma temperatura de cerca de $21^{\circ} \mathrm{C}$. 
Tabela 25 - Taxas de contagens corrigidas $\left(A_{0}\right)$ para o tempo de decaimento $t_{0}=0$ dos padrões sintéticos de mercúrio em função de tempos de decaimento. Condições de irradiação utilizadas: cápsula e involucro de polietileno e tempos de irradiação de 1 e 8 h.

\begin{tabular}{|c|c|c|c|c|c|c|}
\hline \multirow{3}{*}{$\begin{array}{c}\text { Tempo de } \\
\text { decaimento, dias }\end{array}$} & \multicolumn{6}{|c|}{ Condições avaliadas } \\
\hline & \multicolumn{2}{|c|}{$\begin{array}{l}1 \mathrm{~h} \text { de irradiação em cápsula de } \\
\text { polietileno }\end{array}$} & \multicolumn{2}{|c|}{$\begin{array}{l}1 \mathrm{~h} \text { de irradiação em invólucro de } \\
\text { polietileno }\end{array}$} & \multicolumn{2}{|c|}{$\begin{array}{l}8 \text { h de irradiação em invólucro de } \\
\text { polietileno }\end{array}$} \\
\hline & ${ }^{197} \mathrm{Hg}$ & ${ }^{203} \mathrm{Hg}$ & ${ }^{197} \mathrm{Hg}$ & ${ }^{203} \mathrm{Hg}$ & ${ }^{197} \mathrm{Hg}$ & ${ }^{203} \mathrm{Hg}$ \\
\hline 7 & $108,44 \pm 0,31$ & $4,611 \pm 0,031$ & $120,15 \pm 0,32$ & $6,498 \pm 0,036$ & $716,27 \pm 0,86$ & $38,140 \pm 0,092$ \\
\hline 9 & $109,77 \pm 0,41$ & $4,691 \pm 0,031$ & $120,75 \pm 0,42$ & $6,510 \pm 0,037$ & $711,1 \pm 1,1$ & $37,266 \pm 0,089$ \\
\hline 10 & $108,07 \pm 0,75^{*}$ & $4,534 \pm 0,031^{*}$ & $91,93 \pm 0,42$ & $6,278 \pm 0,036$ & $719,0 \pm 1,9$ & $37,51 \pm 0,21$ \\
\hline 14 & $108,95 \pm 0,60^{* *}$ & $4,601 \pm 0,032^{* *}$ & $121,39 \pm 0,84$ & $6,488 \pm 0,038$ & $722,9 \pm 2,2$ & $37,793 \pm 0,094$ \\
\hline
\end{tabular}

* Medição realizada após 11 dias de decaimento; ** Medição realizada após 12 dias de decaimento.

Fonte: autora da dissertação. 
Figura 20 - Taxas de contagens obtidas nas contagens do padrão sintético de mercúrio em função do tempo de decaimento pela medida do ${ }^{197} \mathrm{Hg}$ (a) e pela medida do ${ }^{203} \mathrm{Hg}$ (b) para diferentes condições de irradiação.

(a)

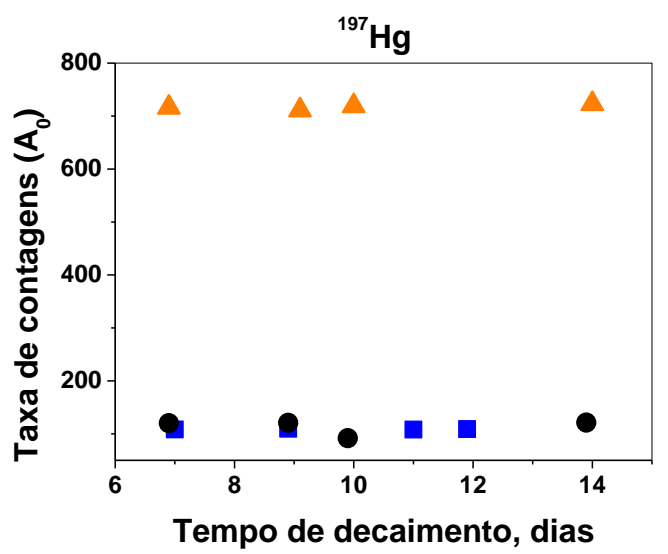

- $1 \mathrm{~h}$ em cápsula

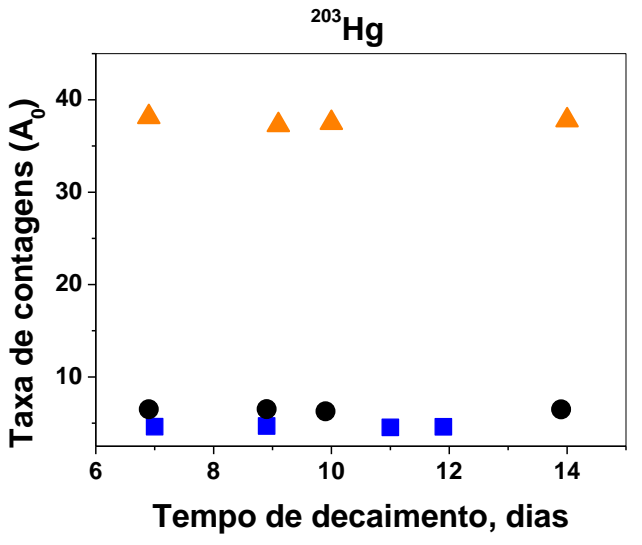

A $8 \mathrm{~h}$ em invólucro

Fonte: autora da dissertação.

Com base nos ensaios realizados, optou-se, para a determinação do $\mathrm{Hg}$, por utilizar como recipiente de irradiação o invólucro de polietileno, devido ao seu baixo custo e sua facilidade de aquisição, e tempo de irradiação de $1 \mathrm{~h}$, para evitar o problema das interferências espectrais do ${ }^{75} \mathrm{Se}$ e, possivelmente, do ${ }^{198} \mathrm{Au}$, que foram identificadas na irradiação de $8 \mathrm{~h}$. Além disso, no caso da irradiação em invólucro de polietileno, é possível enviar em cada irradiação um número maior de amostras.

6.4.2 Resultados de mercúrio nos materiais de referência certificados

Os resultados (frações mássicas médias, desvios padrão, desvios padrão relativos, valores de HORRAT, erros relativos e $Z$ score) obtidos nas determinações de $\mathrm{Hg}$ nos MRCs estão apresentados na Tabela 26 juntamente aos valores dos certificados para comparação. Nessa Tabela, esses resultados estão apresentados para diferentes tempos de decaimento utilizados para contagem. 
Para os materiais NCR DOLT-3 Dogfish Liver, BCR 186 Pig Kidney e INCT M-4 Cormorant Tissue, observa-se que as medições realizadas com $4 \mathrm{~d}$ de decaimento apresentaram DPRs e ERs elevados, devido às altas atividades do ${ }^{24} \mathrm{Na}\left(\mathrm{t}_{1 / 2}=14,96 \mathrm{~h}\right)$, que mascararam as atividades menos intensas do ${ }^{197} \mathrm{Hg}$. Todos os parâmetros avaliados apresentaram valores satisfatórios de HORRAT, erro relativo e $Z$ score para todos os materiais, com exceção da medida do pico do ${ }^{197} \mathrm{Hg}$ para o tempo de decaimento de $5 \mathrm{~d}$ no MRC BCR 186 Pig kidney, em que se obteve $\mid Z$ score $\mid>2$. Além disso, pela medida do ${ }^{197} \mathrm{Hg}$, resultados mais consistentes foram obtidos para o tempo de decaimento de 6 d nos MRCs, o que demonstra que esse seria o tempo de decaimento mais adequado para a determinação de $\mathrm{Hg}$ nesses tipos de amostra.

Para os MRCs NCR DOLT-3 Dogfish Liver e BCR 186 Pig Kidney, o Hg não foi determinado pela medida do ${ }^{203} \mathrm{Hg}$, devido à interferência do pico do ${ }^{75} \mathrm{Se}$.

Os resultados individuais das determinações de $\mathrm{Hg}$ nos MRCs estão apresentados na Tabela C.1 do Apêndice C.

Na Tabela 27 encontram-se os LDs e LQs obtidos para esses MRCs e esses limites obtidos pela medida do ${ }^{197} \mathrm{Hg}$ são inferiores ou da mesma ordem de grandeza daqueles obtidos usando o pico do ${ }^{203} \mathrm{Hg}$.

Não foi determinado $\mathrm{Hg}$ nos MRCs INCT-TL-1 Tea leaves, IAEA-336 Trace and minor elements in lichen, BCR 482 Trace elements in lichen e NIST 1566b Oyster tissue devido aos baixos teores desse elemento nesses materiais. 
Tabela 26 - Frações mássicas médias de mercúrio, em $\mu \mathrm{g} \mathrm{g}{ }^{-1}$, obtidas nos MRCs pela medida do ${ }^{197} \mathrm{Hg}$ e do ${ }^{203} \mathrm{Hg}$ e em diferentes tempos de decaimento $\left(\mathrm{td}_{1}, \mathrm{td}_{2}\right.$ e $\left.\mathrm{td}_{3}\right)$.

\begin{tabular}{|c|c|c|c|c|c|c|c|c|}
\hline \multirow[t]{3}{*}{ MRC } & \multirow{3}{*}{$\begin{array}{l}\text { Parâmetros } \\
\text { avaliados }\end{array}$} & \multicolumn{6}{|c|}{ Presente trabalho } & \multirow{3}{*}{$\begin{array}{l}\text { Valor do } \\
\text { certificado }\end{array}$} \\
\hline & & \multicolumn{3}{|c|}{${ }^{197} \mathrm{Hg}, 77,34 \mathrm{keV}$} & \multicolumn{3}{|c|}{${ }^{203} \mathrm{Hg}, 279,20 \mathrm{keV}$} & \\
\hline & & $t d_{1}$ & $\mathrm{td}_{2}$ & $\mathrm{td}_{3}$ & $t d_{1}$ & $\mathrm{td}_{2}$ & $\mathrm{td}^{3}$ & \\
\hline INCT-M4 & $M \pm D P(n)$ & $1,89 \pm 0,24(4)$ & $2,05 \pm 0,11(4)$ & $2,13 \pm 0,11(4)$ & $1,82 \pm 0,33(2)$ & $2,10 \pm 0,34(4)$ & $2,30 \pm 0,23(4)$ & $2,20 \pm 0,14$ \\
\hline \multirow{4}{*}{$\begin{array}{l}\text { Cormorant } \\
\text { tissue }\end{array}$} & DPR,\% & 12,6 & 5,2 & 5,1 & 18,1 & 16,2 & 10,0 & \\
\hline & HORRAT & 0,86 & 0,36 & 0,35 & 1,2 & 1,1 & 0,71 & \\
\hline & ER, \% & 14,2 & 6,7 & 3,1 & 17,2 & 4,6 & 4,3 & \\
\hline & Z score & 1,2 & 1,1 & 0,53 & 1,13 & 0,30 & $-0,40$ & \\
\hline IAEA-085 & $M \pm D P(n)$ & $24,1 \pm 1,4(4)$ & $23,8 \pm 2,1(4)$ & $24,7 \pm 2,7(4)$ & $24,9 \pm 1,8(4)$ & $24,9 \pm 2,4(4)$ & $25,0 \pm 1,9(4)$ & $23,2 \pm 0,8$ \\
\hline \multirow{4}{*}{$\begin{array}{l}\text { Human } \\
\text { hair }\end{array}$} & DPR,\% & 5,6 & 8,8 & 11,1 & 7,3 & 9,5 & 7,6 & \\
\hline & HORRAT & 0,56 & 0,89 & 1,1 & 0,74 & 0,96 & 0,77 & \\
\hline & ER, \% & 4,1 & 2,5 & 6,5 & 7,2 & 7,2 & 7,9 & \\
\hline & Z score & $-0,27$ & $-0,15$ & $-0,36$ & $-0,45$ & $-0,41$ & $-0,49$ & \\
\hline NCR & $M \pm D P(n)$ & $3,10 \pm 0,36(4)$ & $3,18 \pm 0,20(4)$ & $3,65 \pm 0,24(4)$ & 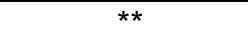 & & & $3,37 \pm 0,14$ \\
\hline DOLT-3 & DPR,\% & 11,5 & 6,4 & 6,5 & & & & \\
\hline Dogfish & HORRAT & 0,23 & 0,24 & 0,28 & & & & \\
\hline \multirow[t]{2}{*}{ liver } & ER, \% & 8,0 & 5,6 & 8,3 & & & & \\
\hline & Z score & $-0,74$ & $-0,87$ & 1,1 & & & & \\
\hline BCR 186 & $M \pm D P(n)$ & $1,58 \pm 0,27(4)$ & $1,65 \pm 0,13(4)$ & $1,78 \pm 0,16(4)$ & & & & $1,97 \pm 0,04$ \\
\hline \multirow[t]{4}{*}{ Pig kidney } & DPR,\% & 17,1 & 8,2 & 9,3 & & & & \\
\hline & HORRAT & 1,1 & 0,55 & 0,63 & & & & \\
\hline & ER, \% & 19,9 & 16,1 & 2,7 & & & & \\
\hline & Z score & $-1,5$ & $-2,3$ & $-1,2$ & & & & \\
\hline
\end{tabular}

* MRCs Cormorant tissue, Dogfish liver e Pig kidney: $\operatorname{td}_{1}=4$ dias; $\operatorname{td}_{2}=5$ dias; $\operatorname{td}_{3}=6$ dias. MRC Human hair: $\operatorname{td}_{1}=1$ dia; $\operatorname{td}_{2}=2$ dias; $\operatorname{td}_{3}=5$ dias; ** Espaço em branco indica que não foi possível determinar Hg; M \pm DP: Média aritmética e desvio padrão; n: número de determinações; DPR: desvio padrão relativo; ER: erro relativo.

Fonte: autora da dissertação. 
Tabela 27 - Limites de detecção (LD) e de quantificação (LQ) de mercúrio, em $\mu \mathrm{g}$ $\mathrm{g}^{-1}$, obtidos para os materiais de referência certificados analisados.

\begin{tabular}{|c|c|c|c|c|c|}
\hline \multirow[t]{2}{*}{ MRC } & \multicolumn{2}{|c|}{${ }^{197} \mathrm{Hg}$} & \multicolumn{2}{|c|}{${ }^{203} \mathrm{Hg}$} & \multirow{2}{*}{$\begin{array}{l}\text { Valor do } \\
\text { certificado }\end{array}$} \\
\hline & LD & $\overline{L Q}$ & LD & $\overline{L Q}$ & \\
\hline Cormorant tissue & 0,1 & 0,4 & 0,22 & 0,65 & $2,20 \pm 0,14$ \\
\hline Human hair & 0,05 & 0,15 & 0,4 & 1,2 & $23,2 \pm 0,8$ \\
\hline Dogfish liver & 0,7 & 2,2 & * & & $3,37 \pm 0,14$ \\
\hline Pig kidney & 0,12 & 0,36 & & & $1,97 \pm 0,04$ \\
\hline
\end{tabular}

* Espaço em branco indica que não foi determinado.

Fonte: autora da dissertação.

\subsubsection{Resultados de mercúrio nas amostras de biomonitores}

O Hg não foi detectado em nenhuma das amostras de biomonitores da poluição atmosférica analisadas. Os LDs e LQs foram calculados para esse elemento usando os fotopicos do ${ }^{197} \mathrm{Hg}$ e do ${ }^{203} \mathrm{Hg}$, cujos resultados estão na Tabela 28. De acordo com Martín et al. (2013), esse elemento está naturalmente presente no ambiente em concentrações muito baixas (entre 0,005 e 0,06 ng m-3 no ar).

Chiarantini et al. (2016) determinaram $\mathrm{Hg}$ por meio de um analisador direto de mercúrio (DMA) em cascas de árvore de espécie Pinus nigra coletadas nas proximidades de uma antiga mina de $\mathrm{Hg}$ e de uma usina geotérmica no Monte Amiata, na Itália. Na região mais poluída, próxima à antiga mina de $\mathrm{Hg}$, foram obtidas frações mássicas de até $8,6 \mu \mathrm{g} \mathrm{g}^{-1}$ de $\mathrm{Hg}$. Já na região de controle e nas proximidades da usina geotérmica, frações mássicas bem menores desse elemento, entre 0,019 e 0,803 $\mu \mathrm{g} \mathrm{g}^{-1}$, foram obtidas.

Os resultados de LD obtidos para o pico de raios gama do ${ }^{197} \mathrm{Hg}$ foram inferiores aos obtidos para o do ${ }^{203} \mathrm{Hg}$, isso devido às características dos isótopos alvos destas reações nucleares, como a secção de choque para nêutrons e a meia-vida. 
Tabela 28 - Limites de detecção (LD) e de quantificação (LQ) de mercúrio, em $\mu g$ $\mathrm{g}^{-1}$, obtidos nas análises de biomonitores da poluição atmosférica.

\begin{tabular}{|c|c|c|c|c|}
\hline \multirow{2}{*}{$\begin{array}{l}\text { Código da } \\
\text { amostra }\end{array}$} & \multicolumn{2}{|c|}{${ }^{197} \mathrm{Hg}$} & \multicolumn{2}{|c|}{${ }^{203} \mathrm{Hg}$} \\
\hline & LD & LQ & LD & $\mathrm{LQ}$ \\
\hline \multicolumn{5}{|c|}{ Amostras de casca de árvore } \\
\hline $\mathrm{C} 1$ & 0,07 & 0,22 & 0,7 & 2,1 \\
\hline $\mathrm{C} 2$ & 0,08 & 0,24 & 0,8 & 2,3 \\
\hline C3 & 0,14 & 0,42 & 1,9 & 5,8 \\
\hline C4 & 0,1 & 0,3 & 1,6 & 4,8 \\
\hline C5 & 0,07 & 0,22 & 1,0 & 3,0 \\
\hline C6 & 0,01 & 0,03 & 0,06 & 0,18 \\
\hline C7 & 0,15 & 0,47 & 1,2 & 3,7 \\
\hline C8 & 0,14 & 0,41 & 1,7 & 5,1 \\
\hline C9 & 0,09 & 0,26 & 1,1 & 3,5 \\
\hline C10 & 0,08 & 0,23 & 0,9 & 2,7 \\
\hline C11 & 0,12 & 0,37 & 1,6 & 4,8 \\
\hline $\mathrm{C} 12$ & 0,17 & 0,53 & 2,3 & 7,1 \\
\hline \multicolumn{5}{|c|}{ Amostra de líquen } \\
\hline L1 & 0,07 & 0,22 & 0,9 & 2,7 \\
\hline \multicolumn{5}{|c|}{ Amostras de bromélia } \\
\hline B1 & 0,2 & 0,6 & 2 & 6 \\
\hline $\mathrm{B} 2$ & 0,1 & 0,3 & 1,0 & 3,1 \\
\hline B3 & 0,7 & 2,0 & 6,8 & 20,7 \\
\hline B4 & 0,13 & 0,40 & 1,8 & 5,4 \\
\hline
\end{tabular}

Fonte: autora da dissertação.

\subsection{Condições experimentais apropriadas estabelecidas para a determinação de As, Cu e Hg}

Com base nos resultados de As, $\mathrm{Cu}$ e $\mathrm{Hg}$ obtidos neste trabalho, foram estabelecidas as condições experimentais adequadas, apresentadas na Tabela 29 para as determinações destes três elementos pelo método de NAA. 
Tabela 29 - Condições apropriadas para a determinação de As, Cu e Hg por NAA (Intervalo de fluxo de nêutrons térmicos $=4,2 \times 10^{12}$ a $4,6 \times 10^{12} \mathrm{n} \mathrm{cm}^{-2} \mathrm{~s}^{-1}$; Invólucro de irradiação: invólucro de polietileno).

\begin{tabular}{ccccc}
\hline Elemento & $\mathrm{t}_{\mathrm{i}}, \mathrm{h}$ & $\mathrm{t}_{\mathrm{d}}, \mathrm{d}$ & $\begin{array}{c}\text { Radionuclídeo } \\
\text { medido }\end{array}$ & $\begin{array}{c}\text { Energia de raios } \\
\text { gama, keV }\end{array}$ \\
\hline $\mathrm{As}$ & 1 & 1 & ${ }^{76} \mathrm{As}$ & 559,10 \\
$\mathrm{Cu}$ & 1 & 1 & ${ }^{64} \mathrm{Cu}$ & 1345,77 \\
$\mathrm{Hg}$ & 1 & 6 & ${ }^{197} \mathrm{Hg}$ & 77,34 \\
\hline
\end{tabular}

$t_{i}=$ tempo de irradiação; $t_{d}=$ tempo de decaimento.

Fonte: autora da dissertação.

No caso do $\mathrm{Hg}$, como esse elemento não foi detectado nas amostras de biomonitores, as condições apropriadas foram escolhidas de acordo com os resultados dos ensaios preliminares, da determinação desse elemento nos MRCs e dos limites de detecção de $\mathrm{Hg}$ obtidos nos biomonitores. O tempo de irradiação de $1 \mathrm{~h}$ foi escolhido para se evitar o problema de interferências espectrais do ${ }^{198} \mathrm{Au}$ e do ${ }^{75} \mathrm{Se}$. No caso do tempo de decaimento, observou-se que os resultados obtidos nos MRCs para $6 \mathrm{~d}$ de decaimento foram mais consistentes. Quanto ao radionuclídeo medido, escolheu-se a medida do pico de $77,34 \mathrm{keV}$ do ${ }^{197} \mathrm{Hg}$, visto que os LDs obtidos para esse pico nos biomonitores foram inferiores aos obtidos pela medida do pico do ${ }^{203} \mathrm{Hg}$. 


\section{CONCLUSÕES}

Os resultados obtidos neste trabalho permitiram demonstrar a possibilidade de se obter resultados confiáveis e precisos de $\mathrm{As}$, $\mathrm{Cu}$ e $\mathrm{Hg}$ em amostras de biomonitores da poluição atmosférica utilizando a NAA.

Os resultados das impurezas de $\mathrm{As}$, $\mathrm{Cu}$ e $\mathrm{Hg}$ nos invólucros de polietileno e nas tiras de papel-filtro indicaram que as massas desses elementos nesses materiais são muito baixas quando comparadas às massas presentes nas amostras e nos padrões sintéticos podendo ser consideradas desprezíveis. Houve a necessidade de se determinar esses elementos nos invólucros e nas tiras de papel-filtro, uma vez que as suas massas nesses materiais podem variar com o lote e a sua origem.

$\mathrm{Na}$ determinação de $\mathrm{Hg}$ a principal dificuldade a ser enfrentada seria $\mathrm{O}$ problema de perda desse elemento durante a irradiação por volatilização. Entretanto, os ensaios realizados utilizando padrão sintético de $\mathrm{Hg}$ com tioacetamida mostraram que não há perda durante a irradiação, bem como após a irradiação.

Por meio das análises de materiais de referência certificados (MRCs) usando fluxo de nêutrons térmicos de 4,2 × $10^{12}$ a $4,6 \times 10^{12} \mathrm{n} \mathrm{cm}^{-2} \mathrm{~s}^{-1}$ (para irradiações de longa duração) e de $1,9 \times 10^{12} \mathrm{n} \mathrm{cm}^{-2} \mathrm{~s}^{-1}$ (para irradiações curta duração), foi possível definir as condições apropriadas de tempo de irradiação e de decaimento para determinação de As, Cu e $\mathrm{Hg}$.

Os resultados obtidos para As nos MRCs utilizando tempos de irradiação de $1 \mathrm{~h}$ e de decaimento de $1 \mathrm{~d}$ indicaram boa precisão e exatidão, com valores de HORRAT < 2 e de $\mid Z$ score $\mid<2$. Na análise de biomonitores, foram obtidas frações mássicas de As entre $0,132 \pm 0,037 \mu \mathrm{g} \mathrm{g}^{-1}$ e 0,472 \pm 0,031 $\mu \mathrm{g} \mathrm{g}^{-1}$, com valores de HORRAT < 2 e limites de detecção entre 0,017 e 0,04 $\mu g^{-1}$. Os resultados dessas análises demonstraram a viabilidade do procedimento de análise por ativação com nêutrons para a determinação desse elemento nesse tipo de amostra. 
No caso do $\mathrm{Cu}$, pela análise dos MRCs, conclui-se que esse elemento pode ser determinado por meio de irradiações de $20 \mathrm{~s}$ pela medida do ${ }^{66} \mathrm{Cu}$, obtida após cerca de $5 \mathrm{~min}$ de decaimento, e de $1 \mathrm{~h}$ pela medida de ${ }^{64} \mathrm{Cu}$, obtida após $1 \mathrm{~d}$ de decaimento. Entretanto, dependendo da amostra, a alta atividade do ${ }^{24} \mathrm{Na}$ pode interferir na determinação desse elemento nas irradiações de $1 \mathrm{~h}$. Já na determinação desse elemento nas amostras de biomonitores, os resultados das irradiações de $1 \mathrm{~h}$ foram mais adequados que os das irradiações de $20 \mathrm{~s}$, uma vez que os resultados das irradiações de $1 \mathrm{~h}$ apresentaram boa precisão (HORRAT < 2) e valores de limite de detecção entre 4 e $12 \mu \mathrm{g} \mathrm{g}^{-1}$, ou seja, menores que os das irradiações de $20 \mathrm{~s}$, que foram entre 11 e $28 \mu \mathrm{g} \mathrm{g}^{-1}$.

Relativamente aos resultados de Hg nos MRCs, foi concluído que os tempos de irradiação de $1 \mathrm{~h}$ e de decaimento de $6 \mathrm{~d}$ para as contagens foram mais adequadas para determinação desse elemento, tendo em vista que, nas irradiações de $8 \mathrm{~h}$, pode ocorrer o problema de interferências de sobreposição de picos ${ }^{198} \mathrm{Au}$, no pico do ${ }^{197} \mathrm{Hg}$, e ${ }^{75} \mathrm{Se}$, no pico do ${ }^{203} \mathrm{Hg}$. Além disso, foi verificado que, dependendo da amostra, as altas atividades do ${ }^{24} \mathrm{Na}$ mascararam as atividades menos intensas do ${ }^{197} \mathrm{Hg}$, permitindo a obtenção de resultados satisfatórios em contagens realizadas com pelo menos $6 \mathrm{~d}$ de decaimento.

O Hg não foi encontrado em nenhum dos biomonitores analisados. Os LDs obtidos na análise dessas amostras variaram de $0,01 \mu \mathrm{g} \mathrm{g}^{-1}$ a $6,8 \mu \mathrm{g} \mathrm{g}^{-1}$, e os LQs variaram entre 0,03 e 20,7 $\mu \mathrm{g} \mathrm{g}^{-1}$.

Para concluir, pode se dizer que o procedimento de NAA proposto nesse trabalho possibilita a quantificação simultânea de $\mathrm{As}$, $\mathrm{Cu}$ e $\mathrm{Hg}$ com boa exatidão e precisão por meio de irradiações de $1 \mathrm{~h}$ e apresenta potencialidades para uso nas determinações desses elementos, dependendo dos seus teores, em amostras de biomonitores da poluição atmosférica. Deve-se ressaltar que o mérito deste trabalho reside no fato de ter disponibilizado um procedimento de NAA confiável na determinação desses elementos em biomonitores cujos dados são bastante escassos. 
APÊNDICE A - Resultados individuais das frações mássicas de As nos materiais de referência certificados e nas amostras de biomonitores da poluição atmosférica

Tabela A.1 - Resultados individuais das frações mássicas de As nos materiais de referência certificados. Tempo de irradiação $=1 \mathrm{~h}$.

\begin{tabular}{ccc}
\hline MRC & $\mathrm{n}$ & $\mathrm{C} \pm \mathrm{I}, \mu \mathrm{g} \mathrm{g}{ }^{-1}$ \\
\hline $\begin{array}{c}\text { IAEA-336 Trace and minor } \\
\text { elements in lichen }\end{array}$ & 4 & $0,7178 \pm 0,0072 ; 0,6807 \pm 0,0097 ;$ \\
BCR 482 Trace elements in & 4 & $0,6400 \pm 0,0065 ; 0,6836 \pm 0,0070$ \\
lichen & & $0,7640 \pm 0,0080 ; 0,7144 \pm 0,0074$ \\
\hline INCT M-4 Cormorant tissue & 4 & $0,120 \pm 0,012 ; 0,111 \pm 0,013 ;$ \\
& & $0,114 \pm 0,010 ; 0,115 \pm 0,012$ \\
\hline IAEA-085 Human hair & 4 & $0,1247 \pm 0,0024 ; 0,1346 \pm 0,0032 ;$ \\
& & $0,1183 \pm 0,0018 ; 0,1121 \pm 0,0020$ \\
\hline NCR DOLT-3 Dogfish liver & 4 & $9,95 \pm 0,12 ; 10,06 \pm 0,11 ;$ \\
& & $9,701 \pm 0,097 ; 9,298 \pm 0,090$
\end{tabular}

MRC: material de referência certificado; $n$ : número de determinações; C: fração mássica; I: incerteza calculada considerando os erros das medidas das taxas de contagens.

Fonte: autora da dissertação. 
Tabela A.2 - Resultados individuais das frações mássicas de As nas amostras de casca de árvore.

\begin{tabular}{|c|c|c|}
\hline Código da amostra & $\mathrm{n}$ & $\mathrm{C} \pm \mathrm{I}, \mu \mathrm{g} \mathrm{g} \mathrm{g}^{-1}$ \\
\hline \multirow[t]{2}{*}{$\mathrm{C} 1$} & 4 & $0,2743 \pm 0,0075 ; 0,2412 \pm 0,0023$ \\
\hline & & $0,3213 \pm 0,0053 ; 0,3354 \pm 0,0070$ \\
\hline \multirow[t]{2}{*}{$\mathrm{C} 2$} & 4 & $0,3368 \pm 0,0056 ; 0,3049 \pm 0,0028$ \\
\hline & & $0,3050 \pm 0,0051 ; 0,3436 \pm 0,0085$ \\
\hline \multirow[t]{2}{*}{ C3 } & 4 & $0,2293 \pm 0,0076 ; 0,2280 \pm 0,0064$ \\
\hline & & $0,2126 \pm 0,0068 ; 0,2022 \pm 0,0084$ \\
\hline \multirow[t]{2}{*}{ C4 } & 4 & $0,2379 \pm 0,0063 ; 0,2642 \pm 0,0057$ \\
\hline & & $0,3152 \pm 0,0059 ; 0,2306 \pm 0,0051$ \\
\hline \multirow[t]{2}{*}{ C5 } & 4 & $0,3326 \pm 0,0049 ; 0,2986 \pm 0,0071$ \\
\hline & & $0,2532 \pm 0,0057 ; 0,2373 \pm 0,0053$ \\
\hline \multirow[t]{2}{*}{ C6 } & 4 & $0,2341 \pm 0,0053 ; 0,2936 \pm 0,0062$ \\
\hline & & $0,2067 \pm 0,0039 ; 0,2448 \pm 0,0058$ \\
\hline \multirow[t]{2}{*}{$\mathrm{C7}$} & 4 & $0,495 \pm 0,010 ; 0,4791 \pm 0,0072$ \\
\hline & & $0,4223 \pm 0,0054 ; 0,4244 \pm 0,0068$ \\
\hline \multirow[t]{2}{*}{ C8 } & 4 & $0,4334 \pm 0,0086 ; 0,5008 \pm 0,0059$ \\
\hline & & $0,4928 \pm 0,0068 ; 0,4616 \pm 0,0076$ \\
\hline \multirow[t]{2}{*}{$\mathrm{C9}$} & 4 & $0,2458 \pm 0,0047 ; 0,2358 \pm 0,0051$ \\
\hline & & $0,2062 \pm 0,0049 ; 0,2109 \pm 0,0050$ \\
\hline \multirow[t]{2}{*}{ C10 } & 4 & $0,1296 \pm 0,0042 ; 0,1092 \pm 0,0067$ \\
\hline & & $0,1854 \pm 0,0040 ; 0,1032 \pm 0,0050$ \\
\hline \multirow[t]{2}{*}{ C11 } & 4 & $0,2679 \pm 0,0068 ; 0,2956 \pm 0,0052$ \\
\hline & & $0,2170 \pm 0,0066 ; 0,2589 \pm 0,0048$ \\
\hline \multirow[t]{2}{*}{ C12 } & 4 & $0,3017 \pm 0,0088 ; 0,316 \pm 0,010$ \\
\hline & & $0,3117 \pm 0,0099 ; 0,3112 \pm 0,0059$ \\
\hline
\end{tabular}

n: número de determinações; C: fração mássica; I: incerteza calculada considerando os erros das medidas das taxas de contagens.

Fonte: autora da dissertação. 
Tabela A.3 - Resultados individuais das frações mássicas de As na amostra de líquen.

\begin{tabular}{ccc}
\hline Código da amostra & $\mathrm{n}$ & $\mathrm{C} \pm \mathrm{I}, \mu \mathrm{g} \mathrm{g}{ }^{-1}$ \\
\hline $\mathrm{L} 1$ & 4 & $0,3371 \pm 0,0058 ; 0,3731 \pm 0,0051 ;$ \\
& & $0,3718 \pm 0,0031 ; 0,2998 \pm 0,0060$ \\
\hline
\end{tabular}

n: número de determinações; $\mathrm{C}$ : fração mássica; I: incerteza calculada considerando os erros das medidas das taxas de contagens.

Fonte: autora da dissertação.

Tabela A.4 - Resultados individuais das frações mássicas de As nas amostras de bromélia analisadas.

\begin{tabular}{ccc}
\hline Código da amostra & $\mathrm{n}$ & $\mathrm{C} \pm \mathrm{I}, \mu \mathrm{g} \mathrm{g}{ }^{-1}$ \\
\hline B1 & 4 & $0,2110 \pm 0,0072 ; 0,2249 \pm 0,0067 ;$ \\
& & $0,1098 \pm 0,0068 ; 0,1132 \pm 0,0076$ \\
\hline B2 & 4 & $0,2673 \pm 0,0051 ; 0,2139 \pm 0,0044 ;$ \\
& & $0,1284 \pm 0,0042 ; 0,1369 \pm 0,0045$ \\
B4 & 4 & $0,2755 \pm 0,0047 ; 0,2362 \pm 0,0045 ;$ \\
& & $0,2339 \pm 0,0065 ; 0,3348 \pm 0,0076$
\end{tabular}

n: número de determinações; $\mathrm{C}$ : fração mássica; I: incerteza calculada considerando os erros das medidas das taxas de contagens.

Fonte: autora da dissertação. 
APÊNDICE B - Resultados individuais das frações mássicas de Cu nos materiais de referência certificados e nas amostras de biomonitores da poluição atmosférica

Tabela B.1 - Resultados individuais das frações mássicas de Cu nos materiais de referência certificados irradiados por $20 \mathrm{~s}$.

\begin{tabular}{ccc}
\hline MRC & $\mathrm{n}$ & $\mathrm{C} \pm \mathrm{I}, \mathrm{fg} \mathrm{g}^{-1}$ \\
\hline INCT-M4 Cormorant tissue & 4 & $19,64 \pm 2,47 ; 19,9 \pm 2,0 ;$ \\
& & $18,3 \pm 2,1 ; 17,4 \pm 1,9$ \\
\hline IAEA-085 Human hair & 4 & $16,1 \pm 1,5 ; 15,3 \pm 1,3 ;$ \\
& & $17,9 \pm 1,4 ; 18,4 \pm 1,2$ \\
\hline NCR DOLT-3 Dogfish liver & 4 & $29,5 \pm 3,7 ; 33,5 \pm 4,4 ;$ \\
& & $25,5 \pm 3,6 ; 37,6 \pm 4,6$ \\
\hline NIST 1577b Bovine liver & 4 & $162,1 \pm 3,9 ; 172,8 \pm 4,4 ;$ \\
& & $178,1 \pm 4,0 ; 166,7 \pm 4,0$ \\
\hline NIST 1566b Oyster tissue & 4 & $67,8 \pm 4,1 ; 72,8 \pm 4,0 ;$ \\
& & $79,4 \pm 4,5 ; 71,9 \pm 4,3$ \\
\hline BCR 186 Pig kidney & 4 & $29,7 \pm 3,6 ; 32,3 \pm 4,3 ;$ \\
& & $30,9 \pm 4,5 ; 28,9 \pm 4,3$
\end{tabular}

MRC: material de referência certificado; $n$ : número de determinações; $\mathrm{C}$ : fração mássica; I: incerteza calculada considerando os erros das medidas das taxas de contagens.

Fonte: autora da dissertação. 
Tabela B.2 - Resultados individuais das frações mássicas de Cu nos materiais de referência certificados irradiados por $1 \mathrm{~h}$.

\begin{tabular}{cccc}
\hline & & \multicolumn{2}{c}{$\mathrm{C} \pm \mathrm{I}, \mathrm{\mu g} \mathrm{g}^{-1}$} \\
\cline { 3 - 4 } MRC & $\mathrm{n}$ & $\mathrm{td}_{1}$ & $\mathrm{td}_{2}$ \\
\hline IAEA-085 & 4 & $20,2 \pm 1,0 ; 17,2 \pm 2,0 ;$ & $19,6 \pm 1,1 ; 16,8 \pm 2,2 ;$ \\
Human hair & & $19,29 \pm 0,83 ; 15,0 \pm 1,1$ & $15,75 \pm 0,73 ; 13,42 \pm 0,93$ \\
\hline INCT TL-1 & 4 & $16,2 \pm 3,6 ; 22,7 \pm 3,6 ;$ & $21,4 \pm 6,2 ; 17,2 \pm 3,0 ;$ \\
Tea leaves & & $18,9 \pm 3,3 ; 24,1 \pm 3,7$ & $25,2 \pm 3,2 ; 21,7 \pm 3,0$ \\
\hline
\end{tabular}

MRC: material de referência certificado; $n$ : número de determinações; C: fração mássica; I: incerteza calculada considerando os erros das medidas das taxas de contagens.

Fonte: autora da dissertação. 
Tabela B.3 - Resultados individuais das frações mássicas de Cu nas amostras de casca de árvore irradiadas por $1 \mathrm{~h}$.

\begin{tabular}{|c|c|c|}
\hline Código da amostra & $\mathrm{n}$ & $\mathrm{C} \pm \mathrm{I}, \mu \mathrm{g} \mathrm{g}^{-1}$ \\
\hline \multirow[t]{2}{*}{$\mathrm{C} 1$} & 4 & $46,2 \pm 5,0 ; 37,0 \pm 2,8$ \\
\hline & & $41,0 \pm 4,6 ; 46,4 \pm 4,6$ \\
\hline \multirow[t]{2}{*}{$\mathrm{C} 2$} & 4 & $56,6 \pm 4,2 ; 66,9 \pm 5,6$ \\
\hline & & $55,9 \pm 3,5 ; 67,3 \pm 3,7$ \\
\hline \multirow[t]{2}{*}{ C3 } & 4 & $56,0 \pm 3,9 ; 60,8 \pm 3,5$ \\
\hline & & $56,5 \pm 3,5 ; 55,7 \pm 3,5$ \\
\hline \multirow[t]{2}{*}{$\mathrm{C} 4$} & 4 & $287,0 \pm 6,2 ; 293,2 \pm 4,8$ \\
\hline & & $256,3 \pm 3,9 ; 255,1 \pm 4,0$ \\
\hline \multirow[t]{2}{*}{ C5 } & 4 & $29,8 \pm 3,2 ; 22,8 \pm 2,9$ \\
\hline & & $19,7 \pm 2,5 ; 20,3 \pm 2,7$ \\
\hline \multirow[t]{2}{*}{ C6 } & 4 & $27,4 \pm 2,9 ; 26,2 \pm 3,3$ \\
\hline & & $25,2 \pm 2,1 ; 30,6 \pm 3,0$ \\
\hline \multirow[t]{2}{*}{$\mathrm{C7}$} & 3 & $26,9 \pm 5,0 ; 27,7 \pm 4,1$ \\
\hline & & $26,2 \pm 3,7$ \\
\hline \multirow[t]{2}{*}{ C8 } & 4 & $33,2 \pm 3,4 ; 44,5 \pm 3,0$ \\
\hline & & $33,4 \pm 3,3 ; 43,6 \pm 5,0$ \\
\hline \multirow[t]{2}{*}{ C9 } & 4 & $16,9 \pm 2,3 ; 19,9 \pm 1,7$ \\
\hline & & $21,0 \pm 2,3 ; 17,4 \pm 3,1$ \\
\hline \multirow[t]{2}{*}{ C10 } & 4 & $27,5 \pm 3,1 ; 24,7 \pm 3,4$ \\
\hline & & $26,4 \pm 2,6 ; 31,9 \pm 3,4$ \\
\hline \multirow[t]{2}{*}{ C11 } & 4 & $25,6 \pm 3,8 ; 26,2 \pm 3,2$ \\
\hline & & $28,5 \pm 3,8 ; 29,7 \pm 3,1$ \\
\hline \multirow[t]{2}{*}{ C12 } & 4 & $26,7 \pm 7,3 ; 27,6 \pm 4,7$ \\
\hline & & $21,6 \pm 4,6 ; 30,9 \pm 3,1$ \\
\hline
\end{tabular}

n: número de determinações; C: fração mássica; I: incerteza calculada considerando os erros das medidas das taxas de contagens.

Fonte: autora da dissertação. 
Tabela B.4 - Resultados individuais das frações mássicas de Cu nas amostras de casca de árvore irradiadas por $20 \mathrm{~s}$.

\begin{tabular}{|c|c|c|}
\hline Código da amostra & $\mathrm{n}$ & $\mathrm{C} \pm \mathrm{I}, \mu \mathrm{g} \mathrm{g}^{-1}$ \\
\hline \multirow[t]{2}{*}{$\mathrm{C} 1$} & 4 & $32,3 \pm 9,1 ; 31,9 \pm 9,0$ \\
\hline & & $33,9 \pm 9,6 ; 22,0 \pm 8,6$ \\
\hline \multirow[t]{2}{*}{$\mathrm{C} 2$} & 4 & $46 \pm 10 ; 52 \pm 11$ \\
\hline & & $44 \pm 11 ; 53 \pm 20$ \\
\hline \multirow[t]{2}{*}{ C3 } & 4 & $68,1 \pm 8,9 ; 49,7 \pm 6,6$ \\
\hline & & $52,8 \pm 5,8 ; 60,9 \pm 8,1$ \\
\hline \multirow[t]{2}{*}{$\mathrm{C} 4$} & 4 & $255 \pm 15 ; 234 \pm 15$ \\
\hline & & $244 \pm 13 ; 214 \pm 14$ \\
\hline C6 & 1 & $40,5 \pm 9,2$ \\
\hline $\mathrm{C} 7$ & 1 & $29 \pm 14$ \\
\hline $\mathrm{C} 8$ & 2 & $48 \pm 18 ; 32 \pm 11$ \\
\hline C10 & 2 & $24,0 \pm 7,6 ; 22,9 \pm 6,3$ \\
\hline C12 & 2 & $20,4 \pm 5,0 ; 29,9 \pm 6,5$ \\
\hline
\end{tabular}

n: número de determinações; C: fração mássica; I: incerteza calculada considerando os erros das medidas das taxas de contagens.

Fonte: autora da dissertação. 
Tabela B.5 - Resultados individuais das frações mássicas de Cu na amostra de líquen irradiada por $1 \mathrm{~h}$.

\begin{tabular}{ccc}
\hline Código da amostra & $\mathrm{n}$ & $\mathrm{C} \pm \mathrm{I}, \mu \mathrm{g} \mathrm{g}{ }^{-1}$ \\
\hline $\mathrm{L} 1$ & 4 & $17,3 \pm 2,9 ; 13,5 \pm 2,4 ;$ \\
& & $12,6 \pm 2,3 ; 11,1 \pm 2,0$ \\
\hline
\end{tabular}

n: número de determinações; C: fração mássica; I: incerteza calculada considerando os erros das medidas das taxas de contagens.

Fonte: autora da dissertação.

Tabela B.6 - Resultados individuais das frações mássicas de Cu nas amostras de bromélia irradiadas por $1 \mathrm{~h}$.

\begin{tabular}{ccc}
\hline Código da amostra & $\mathrm{n}$ & $\mathrm{C} \pm \mathrm{I}, \mu \mathrm{g} \mathrm{g}$ \\
\hline B1 & 3 & $15,6 \pm 4,5 ; 16,7 \pm 5,0 ;$ \\
& & $19,8 \pm 5,1$ \\
\hline B2 & 4 & $13,0 \pm 4,2 ; 20,7 \pm 3,9 ;$ \\
& & $15,2 \pm 2,9 ; 18,8 \pm 3,5$
\end{tabular}

n: número de determinações; C: fração mássica; I: incerteza calculada considerando os erros das medidas das taxas de contagens.

Fonte: autora da dissertação. 


\section{APÊNDICE C - Resultados individuais das frações mássicas de Hg nos materiais de referência certificados}

Tabela C.1 - Resultados individuais das frações mássicas de Hg nos materiais de referência certificados.

\begin{tabular}{|c|c|c|c|c|c|c|}
\hline \multirow[t]{3}{*}{ MRC } & \multicolumn{6}{|c|}{$\mathrm{C} \pm \mathrm{I}, \mu \mathrm{g} \mathrm{g}^{-1}$} \\
\hline & \multicolumn{3}{|c|}{${ }^{197} \mathrm{Hg}, 77,34 \mathrm{keV}$} & \multicolumn{3}{|c|}{${ }^{203} \mathrm{Hg}, 279,20 \mathrm{keV}$} \\
\hline & $\mathrm{td}_{1}$ & $\mathrm{td}_{2}$ & $\mathrm{td}_{3}$ & $\mathrm{td}_{1}$ & $\mathrm{td}_{2}$ & $\mathrm{td}^{3}$ \\
\hline INCT-M4 & $1,830 \pm 0,088$ & $2,047 \pm 0,023$ & $2,266 \pm 0,021$ & $2,05 \pm 0,26$ & $2,32 \pm 0,18$ & $2,522 \pm 0,088$ \\
\hline Cormorant & $1,587 \pm 0,071$ & $2,047 \pm 0,023$ & $2,064 \pm 0,021$ & $1,59 \pm 0,33$ & $2,10 \pm 0,12$ & $2,346 \pm 0,068$ \\
\hline \multirow[t]{2}{*}{ Tissue } & $1,985 \pm 0,025$ & $1,930 \pm 0,021$ & $2,028 \pm 0,019$ & & $2,35 \pm 0,16$ & $1,973 \pm 0,088$ \\
\hline & $2,146 \pm 0,029$ & $2,191 \pm 0,025$ & $2,171 \pm 0,023$ & & $1,62 \pm 0,15$ & $2,340 \pm 0,081$ \\
\hline IAEA-085 & $25,742 \pm 0,098$ & $26,828 \pm 0,044$ & $25,597 \pm 0,069$ & $27,59 \pm 0,77$ & $28,23 \pm 0,22$ & $27,82 \pm 0,18$ \\
\hline Human & $22,470 \pm 0,061$ & $22,051 \pm 0,040$ & $22,317 \pm 0,055$ & $23,82 \pm 0,37$ & $23,67 \pm 0,15$ & $23,58 \pm 0,14$ \\
\hline \multirow[t]{2}{*}{ Hair } & $23,862 \pm 0,054$ & $23,009 \pm 0,035$ & $23,435 \pm 0,055$ & $24,31 \pm 0,37$ & $22,93 \pm 0,16$ & $24,66 \pm 0,15$ \\
\hline & $24,499 \pm 0,065$ & $23,264 \pm 0,052$ & $24,525 \pm 0,076$ & $23,76 \pm 0,43$ & $24,62 \pm 0,24$ & $24,09 \pm 0,20$ \\
\hline NCR & $2,64 \pm 0,16$ & $3,310 \pm 0,029$ & $3,453 \pm 0,032$ & ** & & \\
\hline DOLT-3 & $3,36 \pm 0,16$ & $3,38 \pm 0,10$ & $3,934 \pm 0,054$ & & & \\
\hline \multirow[t]{2}{*}{ Dogfish } & $3,40 \pm 0,16$ & $3,10 \pm 0,11$ & $3,765 \pm 0,55$ & & & \\
\hline & $2,99 \pm 0,16$ & $2,94 \pm 0,10$ & $3,452 \pm 0,049$ & & & \\
\hline BCR 186 & $1,176 \pm 0,217$ & $1,557 \pm 0,064$ & $1,736 \pm 0,073$ & & & \\
\hline \multirow[t]{3}{*}{ Pig Kidney } & $1,740 \pm 0,071$ & $1,628 \pm 0,070$ & $1,804 \pm 0,051$ & & & \\
\hline & $1,728 \pm 0,081$ & $1,849 \pm 0,024$ & $1,986 \pm 0,026$ & & & \\
\hline & $1,666 \pm 0,080$ & $1,573 \pm 0,048$ & $1,589 \pm 0,053$ & & & \\
\hline
\end{tabular}

MRC: material de referência certificado; C: fração mássica; I: incerteza calculada considerando os erros das medidas das taxas de contagens:

** Espaço em branco indica que não o $\mathrm{Hg}$ não foi determinado devido ao problema de interferência do Se.

Fonte: autora da dissertação. 


\section{REFERÊNCIAS BIBLIOGRÁFICAS}

AHMED, M.; CHIN, Y. H.; GUO, X.; ZHAO, X. M. Microwave assisted digestion followed by ICP-MS for determination of trace metals in atmospheric and lake ecosystem. Journal of Environmental Sciences, v. 55, p. 1-10, 2016.

ALMEIDA, S. M.; RAMOS, C. A.; MARQUES, A. M.; SILVA, A. V.; FREITAS, M. C.; FARINHA, M. M.; REIS M.; MARQUES, A. P. Use of INAA and PIXE for multipollutant air quality assessment and management. Journal of Radioanalytical and Nuclear Chemistry, v.294, n. 3, p 343-347, 2012.

ANDERSON, D. L. Use of I-cysteine for minimization of inorganic Hg loss during thermal neutron irradiation. Journal of Radioanalytical and Nuclear Chemistry, v. 282 , n. 1 , p. $11-14,2009$.

BADAWY, W. M.; GHANIM, E. H.; DULIU, O. G.; EL SAMMAN, H.; FRONTASYEVA, M. V. Major and trace element distribution in soil and sediments from the Egyptian central Nile Valley. Journal of African Earth Sciences, v. 131, p. $53-61,2017$.

BARANDOVSKI, L.; STAFILOV, T.; SAJN, R.; FRONTASYEVA, M.; BACEVA, K. Air pollution study in Macedonia using a moss biomonitoring technique, ICP-AES and AAS. Macedonian Journal of Chemistry and Chemical Engineering, v. 32, n. 1 , p. $89-107,2013$.

BATTISTA, G.; DE LIETO VOLLARO, R. Correlation between air pollution and weather data in urban areas: Assessment of the city of Rome (Italy) as spatially and temporally independent regarding pollutants. Atmospheric Environment, v. 165, p. $240-427,2017$.

BCR. COMMUNITY BUREAU OF REFERENCE. Certificate of analysis, BCR 482, Trace elements in lichen, 1995.

BCR. COMMUNITY BUREAU OF REFERENCE. Certificate of analysis, BCR 186, Trace elements in lyophilized pig kidney, 1986.

BEDREGAL, P. S.; MENDOZA, P. A.; UBILLUS, M. S.; COHEN, I. M.; MONTOYA, E. $\mathrm{H}$. The $\mathrm{kO}$ and relative INAA methods to determine elements in entire archaeological pottery objects. Journal of Radioanalytical and Nuclear Chemistry, v. 300, n. 2, p. $673-678,2014$.

BERLIZOV A.; BLUM, O. B.; FILBY, R. H.; MALYUK, I. A.; TRYSHYN, V. V. Testing applicability of black poplar (Populus nigra L.) bark to heavy metal air pollution monitoring in urban and industrial regions. Science of the Total Environment, v. 372, n. 2-3, p. 693 - 706, 2007.

BERMUDEZ, G. M.; RODRIGUEZ, J. H.; PIGNATA, M. L. Comparison of the air pollution biomonitoring ability of three Tillandsia species and the lichen Ramalina celastri in Argentina. Environmental Research, v. 109, n. 1, p. 6-14, 2009. 
BILO, F.; BORGESE, L.; DALIPI, R.; ZACCO, A.; FEDERICI, S.; MASPERI, M.; LEONESIO, P.; BONTEMPI, E; DEPERO, L. E. Elemental analysis of tree leaves by total reflection X-ray fluorescence: New approaches for air quality monitoring. Chemosphere, v. 178, p. $504-512,2017$.

CESNEK, M.; ŠTEFÁNIK, M.; MIGLIERINI, M.; KMJEČ, T.; SKLENKA, L. U. Analysis of traditional Tibetan pills. Hyperfine Interactions, v. 238, n. 1, p. $93-$ 98, 2017.

CHIARANTINI, L.; RIMONDI, V.; BENVENUTI, M.; BEUTEL, M. W.; COSTAGLIOLA, P.; GONNELLI, C.; LATTANZI, P.; PAOLIERI, M. Black pine (Pinus nigra) barks as biomonitors of airborne mercury pollution. Science of the Total Environment, v. 569, p. $105-113,2016$.

CONTI, M. E.; JASAN,R.; FINOIA, M. G.; IAVICOLI, I. Trace elements deposition in the Tierra del Fuego region (South Patagonia) by using lichen transplants after the Puyehue-Cordón Caulle (North Patagonia) volcanic eruption in 2011. Environmental Science and Pollution Research, v. 23, n. 7, p. $6574-6583$, 2016.

COSTA, L. A. Análise por ativação neutrônica: estudo de interferências primárias nas determinações de alumínio, magnésio, manganês e sódio. 2007. p. 22. Dissertação (Mestrado em Ciência e Tecnologia das Radiações, Minerais e Materiais). Disponível em: < http://www.bdtd.cdtn.br/tde_arquivos/3/TDE-2008-06-12T113907Z-

43/Publico/Dissertacao\%20Leonardo\%20Alves\%20da\%20Costa.pdf> Acesso em 25/01/2018.

CURRIE, L.A. International recommendations offered on analytical detection and quantification concepts and nomenclature. Analytica Chimica Acta, v.391, p.127134, 1999.

DE SOETE, D.; GILBELS, R.; HOSTE, J. Neutron activation analysis. New York, Wiley-Interscience, 1972.

DIVSAR, F.; ISAPOUR, N.; KEFAYATI, H.; BADIEI, A.; NEZHADALI, A.; EASAPOUR, S.; YADAVI, M. Fluorene functionalized nanoporous SBA-15 incorporated into carbon paste electrode for trace copper determination. Journal of Porous Material, v. 22, p. 1655 - 1661, 2015.

DRASCH G.A. Mercury. In: SEILER, H.G.; SIGEL, A.; SIGEL, H. (Ed.). Handbook on metals in clinical and analytical chemistry. New York, Marcel Dekker, Inc., 1994.

FREITAS, C. U. D.; JUNGER, W.; LEON, A. P. D.; GRIMALDI, R.; SILVA, M. A. F. R.; GOUVEIA, N. Poluição do ar em cidades brasileiras: selecionando indicadores de impacto na saúde para fins de vigilância. Epidemiologia e Serviços de Saúde, v.22, n.3, p. 445 - 454, 2013. 
FRIEDLANDER, G.; KENNEDY, J. W.; MILLER, J. M., Nuclear and radiochemistry, London, John Wiley \& Sons, 1981.

FUGA, A.; SAIKI, M.; MARCELLI, M. P.; SALDIVA, P. H. N. Atmosferic pollutant monitoring by analysis of epiphytic lichens. Environmental Pollution, v. 151, p. $334-340,2008$.

GOYER, R. A.; CLARKSON, T. W. Toxic effects of metals. In: KLAASSEN, C.D. (Ed.) Casarett \& Doull's Toxicology. The Basic Science of Poisons, New York, McGraw-Hill, Cap. 23, p. 811 - 867, 2001.

GREENBERG, R. R.; BODE, P.; FERNANDES, E. A. N. Neutron activation analysis: a primary method of measurement. Spectrochimica Acta Part B: Atomic Spectroscopy, v. 66, n. 3, p. $193-241,2011$.

haMidATOU, L.; SLAMENE, H.; AKHAL, T.; ZOURANEN, B. Concepts, Instrumentation and techniques of neutron activation analysis. In: Imaging and Radioanalytical Techniques in Interdisciplinary Research-Fundamentals and Cutting Edge Applications. InTech, 2013. Disponível em $<$ https://www.intechopen.com/books/imaging-and-radioanalytical-techniques-ininterdisciplinary-research-fundamentals-and-cutting-edge-applications>. Acesso em 20/12/2017.

HORWITZ W.; ALBERT, R. The Horwitz ratio (HorRat): A useful index of method performance with respect to precision. Jornal of AOAC International, v. 89, n. 4, p. $1095-1109,2006$.

IAEA. INTERNATIONAL ATOMIC ENERGY AGENCY. Practical aspects of operating a neutron activation analysis laboratory, IAEA-TEC-DOC-564, 1990.

IAEA. INTERNATIONAL ATOMIC ENERGY AGENCY. Reference sheet, IAEA085, Methylmercury, total mercury and other trace elements in human hair, 2000.

IAEA. INTERNATIONAL ATOMIC ENERGY AGENCY. Reference sheet, IAEA336, Trace and minor elements in lichen, 1999.

IFFLAND R. Arsenic. In: SEILER H.G.; SIGEL, A.; SIGEL H. (Ed.). Handbook on metals in clinical and analytical chemistry. New York, Marcel Dekker, Inc, 1994.

INCT. INSTITUTE OF NUCLEAR CHEMISTRY AND TECHNOLOGY. Certificate of analysis, MODAS-4 Cormorant Tissue, M-4 CormTis, 2015.

INCT. INSTITUTE OF NUCLEAR CHEMISTRY AND TECHNOLOGY. Certificate of analysis, INCT-TL1-1, Tea leaves, 2002.

INSTITUTO NACIONAL DE METROLOGIA, QUALIDADE E TECNOLOGIA. Orientação sobre validação de métodos analíticos. DOQ-CGCRE-008 Revisão

03, 2010.

Disponível

em: 
$<$ http://www.inmetro.gov.br/Sidoq/Arquivos/CGCRE/DOQ/DOQ-CGCRE8_03.pdf>. Acesso em: 10/02/2018.

KNOLL, G. F. Radiation detection and measurement. New York: John Wiley \& Sons, 1989.

KONIECZKA, P.; NAMIESNIK, J. Quality assurance and quality control in the analytical chemical laboratory: a practical approach. Chicago: CRC Press, 2016.

LAZO, P.; STEINNES, E.; QARRI, F.; ALLAJBEU, S.; KANE, S.; STAFILOV, T.; FRONTASYEVA, M. V.; HARMENS, H. Origin and spatial distribution of metals in moss samples in Albania: A hotspot of heavy metal contamination in Europe. Chemosphere, v. 190, p. $337-349,2018$.

LIU, Z.; CHEN, J.; WU, Y.; LI, Y.; ZHAO, J.; NA, P. Synthesis of magnetic orderly mesoporous $\alpha-\mathrm{Fe}_{2} \mathrm{O}_{3}$ nanocluster derived from MIL-100 (Fe) for rapid and efficient arsenic (III, V) removal. Journal of Hazardous Materials, v. 343, p. $304-314$, 2018.

LOVELAND, W. D.; MORRISSEY, D. J.; SEABORG, G. T. Modern nuclear chemistry. New York: John Wiley \& Sons, 2006.

MARKERT, B. Definitions and principles for bioindication and biomonitoring of trace metals in the environment. Journal of Trace Elements in Medicine and Biology, v. 21, p. $77-82,2007$.

MARTíN, J. A. R.; NANOS, N.; MIRANDA, J. C.; CARBONELL, G.; GIL, L. Volcanic mercury in Pinus canariensis. Naturwissenschaften, v. 100, n. 8, p. 739-747, 2013.

MOGHADAM, M. R.; JAHROMI, S. M. P.; DAREHKORDI, A. Simultaneous spectrophotometric determination of copper, cobalt, nickel and iron in foodstuffs and vegetables with a new bis-thiosemicarbazone ligand using chemometric approaches. Food Chemistry, v. 192, p. $424-431,2016$.

MONNA, F.; MARQUES, A. N.; GUILLON, R.; LOSNO, R.; COUETTE, S.; NAVARRO, N.; DONGARRA, G.; TAMBURO, E.; VARRICA, D.; CHATEAU, C.; NEPOMUCENO, F. O. Perturbation vectors to evaluate air quality using lichens and bromeliads: a Brazilian case study. Environmental Monitoring and Assessment, v. 189, n. 11, p. 566 - 576, 2017.

MOREIRA, E. G. Aplicação da análise por ativação com nêutrons ao estudo da composição química de materiais metálicos. 2002. p. 22. Dissertação (Mestrado em Ciências na área de Tecnologia Nuclear - Aplicações). Disponível em:

$<$ http://www.iaea.org/inis/collection/NCLCollectionStore/_Public/41/035/41035622. pdf> Acesso em: 25/01/2018. 
MOREIRA, T. C. L.; DE OLIVEIRA, R. C.; AMATO, L. F. L.; KANG, C. M.; SALDIVA, P. H. N.; SAIKI, M. Intra-urban biomonitoring: source apportionment using tree barks to identify air pollution sources. Environment International, $v$. 91, p. $271-275,2016$.

MORINA, F.; VIDOVIĆ, M.; SREĆKOVIĆ, T.; RADOVIĆ, V.; VELJOVIĆJOVANOVIĆ, S. Biomonitoring of Urban Pollution Using Silicon-Accumulating Species, Phyllostachys aureosulcata 'Aureocaulis'. Bulletin of Environmental Contamination and Toxicology, v. 99, n. 6, p. 706 - 712, 2017.

NCR. NATIONAL RESEARCH COUNCIL CANADA. Certificate of analysis, DOLT-3, Dogfish Liver Certified Reference Material for Trace Metals, 2002.

NIST. NATIONAL INSTITUTE OF STANDARDS AND TECHNOLOGY. Certificate of analysis, SRM 1577b, Bovine Liver, 1991.

NIST. NATIONAL INSTITUTE OF STANDARDS AND TECHNOLOGY. Certificate of analysis, SRM 1566b, Oyster Tissue, 2015.

NOYORI, A.; SAIKI, M.; ZAHN, G. S. Aluminum determination by instrumental neutron activation analysis in tree barks. Journal of Radioanalytical and Nuclear Chemistry, v. 314, n. 2, p. 935 - 940, 2017.

PARRY, S. J. Handbook of neutron activation analysis. Surrey: Viridian Pub., 2003.

PATTERSON, J. W.; PASSINO, R. Metals speciation separation and recovery (Vol. 1). Chicago, CRC Press, 1987.

ROMAN, H. A.; WALSH, T. L.; COULL, B. A.; DEWAILLY, É.; GUALLAR, E.; HATTIS, D.; MARIEN, K.; SCHWARTZ, J.; STERN, A. H.; VIRTANEN, J. K.; RICE, G. Evaluation of the cardiovascular effects of methylmercury exposures: current evidence supports development of a dose-response function for regulatory benefits analysis. Environmental Health Perspectives, v. 119, n. 5, p. $607-614$, 2011.

ŠPIRIĆ, Z.; VUČKOVIĆ, I.; STAFILOV, T.; KUŠAN, V.; BAČEVA, K. Biomonitoring of air pollution with mercury in Croatia by using moss species and CV-AAS. Environmental Monitoring and Assessment, v. 186, n. 7, p. 4357 - 4366, 2014.

TAKEUCHI, T.; SHINOGI, M.; MORI, I. Volatilization losses of mercury in neutron activation analysis. Journal of Radioanalytical Chemistry, v. 53, p. $81-88$, 1979.

TASIĆ, V.; KOVAČEVIĆ, R.; MALUCKOV, B.; APOSTOLOVSKI-TRUJIĆ, T.; MATIĆ, B.; COCIĆ, M.; ŠTEHARNIK, M. The content of As and heavy metals in TSP and PM10 near copper smelter in Bor, Serbia. Water, Air, \& Soil Pollution, v. 228, n. 6 , p. $230-244,2017$. 
TECHATO, K.; SALAEH, A.; VAN BEEM, N. C. Use of atmospheric epiphyte Tillandsia usneoides (Bromeliaceae) as biomonitor. APCBEE Procedia, v. 10, $\mathrm{p}$. $49-53,2014$.

TÖLGYESSY, J.; KYRŠ, M. Radioanalytical chemistry. Chichester: Ellis Horwood, v. 2, 1989

UNITED NATIONS ENVIRONMENT PROGRAMME (UNEP). Global mercury assessment: sources, emissions, releases and environmental transport. UNEP Chemicals Branch, Geneva, Switzerland; 2013.

VAN DER WAT, L.; FORBES, P. B. C. Lichens as biomonitors for organics air pollutants. Trends in Analytical Chemistry, v. 64, p.165 - 172, 2015.

WOOD, R. How to validate analytical methods. Trends in Analytical Chemistry, v. 18, p. $624-632,1999$.

WORLD HEALTH ORGANIZATION (WHO). 7 million premature deaths annually linked to air pollution. WHO. 2014. Disponível em: $<$ http://www.who.int/mediacentre/news/releases/2014/air-pollution/en/> Acesso em 07/12/2017.

XU, Z.; DENG, P.; LI, J.; TANG, S. Fluorescent ion-imprinted sensor for selective and sensitive detection of copper (II) ions. Sensors and Actuators B: Chemical, v. 255 , p. $2095-2104,2018$.

YU, L. L.; WEI, C. ZEISLER, R.; TONG, J.; OFLAZ, R.; BAO, H.; WANG, J. An approach for identification and determination of arsenic species in the extract of kelp. Analytical and Bioanalytical Chemistry, v. 407, n. 12, p. $3517-3524$, 2015.

ŻMIJEWSKA, W. Activation analysis of mercury in environmental samples. Journal of Radioanalytical and Nuclear Chemistry, v. 35, n. 2, p. $389-418$, 1977.

ZHOU, L.; DONG, L.; HUANG, Y. R.; SHI, S. X.; ZHANG, L. F.; ZHANG, X. L., YANG, W. L. Tree bark as a biomonitor for the determination of polychlorinated biphenyls and polybrominated diphenyl ethers from Southern Jiangsu, China: levels, distribution, and possible sources. Environmental Monitoring and Assessment, v. 187, n. 9, p.603-610, 2015. 
INSTITUTO DE PESQUISAS ENERGÉTICAS E NUCLEARES

Diretoria de Pesquisa, Desenvolvimento e Ensino

Av. Prof. Lineu Prestes, 2242 - Cidade Universitária CEP: 05508-000

Fone/Fax(0XX11) 3133-8908

SÃO PAULO - São Paulo - Brasil

http://www.ipen.br

O IPEN é uma Autaquia vinculada à Secretaria de Desenvolvimento, associada à Universiade de São Paulo e gerida técnica e administrativamente pela Comissão Nacional de Energia Nuclear, órgão do Ministério da Ciência, Tecnologia e Inovação. 